\title{
بحث بعنوان
}

المنع من السفر في المواد الجنائية

$$
\begin{aligned}
& \text { إعداد } \\
& \text { دكتور } \\
& \text { محمد السعيد القزعة } \\
& \text { دكتور اه في القانون الجنائي }
\end{aligned}
$$




\section{الملخص}

حظيت حرية السفر والتنقل بالعديد من الضمانات في الثر ائع السماوية والنظم القانونية الوضعية، لما لتلك الحرية من أهمية بالغة لعموم البشر، إلا أن حرية السفر شأنها شأن العديد من الحريات لا تتأبى على التظظيم الذي من شأنه كفالة تمتع عموم أفر اد المجتمع بحرياتهم دون إضر ار بالآخرين؛ لذللك جاء المنع من السفر كأحد القيود الواردة على حرية الإنسان في التنقل.

ويعد المنع من السفر في الجرائم الجنائية الصورة الأبرز لهذا الإجر اء؛ لضرورة التحقيق أو صيانة أمن المجتمع، ولخصوصية المنع من السفر ومساسه المباشر بحرية الإنسان، تضمنت العديد من النظم القانونية المقارنة تنظيمًا مفصلاً لهذا الإجر اء، بما لا يسمح معه بالعصف بحرية الإنسان في السفر، إلا أن المشرع المصري لم يصدر قانون ينظم هذا الإجر اء رغم خطورته وبالمخالفة للاستور، ومؤخرًا تدارك هذا الخلل جزئيًا بإدراجه تنظيم المنع من السفر في بعض القوانين الجنائية المهمة، كقانون الكسب غير المشروع المعدل، وقانون مكافحة الإرهاب، وقانون مكافحة جر ائم تقنية المعلومات، بما بضفي شرعية على قرار المنع من السفر حال اتخاذه في أحد تلك الجر ائم.

\section{Summary}

Freedom of travel and movement has enjoyed many guarantees in the divine laws and statutory legal systems, because of this freedom of great importance to the general population, however, freedom of travel, like many freedoms, does not refrain from organizing that would ensure that the general population enjoys their freedoms without harming others. Therefore, the travel ban came as one of the restrictions on a person's freedom of movement.

The travel ban in criminal offenses is the most prominent form of this measure. Due to the necessity of investigation or maintenance of community security, and the specificity of the travel ban and its direct prejudice to human freedom, many of the comparative legal systems included detailed regulation for this procedure, in a way that does not allow human freedom to travel with it, but the Egyptian legislator did not issue a law regulating this procedure despite its seriousness and violation. Of the constitution, recently partially remedied this defect by including the regulation of travel bans in some important criminal laws, such as the amended Graft Law, the Anti-Terrorism Law, and the Law on Combating Information Technology Crimes, thus giving legitimacy to the travel ban decision if it is taken in one of those crimes. . 


\section{محمد السعبد الفز عهة}

\section{المنع من السفر في المواد الجنائية}

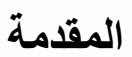

ولدت حرية السفر والتنقل و التصقت بحياة الانسان قبل أن توجد الدول والمجتمعات، وتقوم الحضار ات لأنها من الحريات الطبيعية، وطالما هي كذلك فلا يجوز إلغاؤها أو التنازل عنها، وبذلك تكون سلطة الدولة إزاء تللك الحرية ليست سلطة منح أو تقرير، و إنما هي سلطة تنظيم وحماية من أي عدوان يمكن أن يحد من ممارستها، ويعد السفر

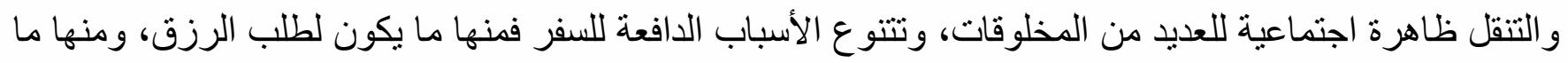
يكون بقصد الدراسة و المعرفة، أو بغرض السياحة، أو حنى هرباً من ويلات الحروب، أو الكوارث الطنات الطبيعية. وتعتبر حرية السفر من حريات الإنسان الأساسية، وحرصت كافة التشريعات القانونية الوضعية عليها، فضلاً

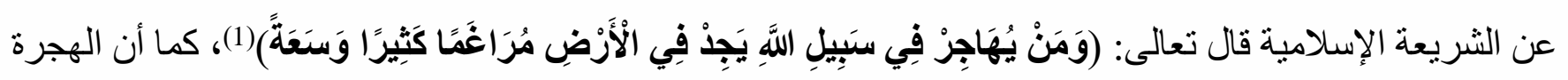

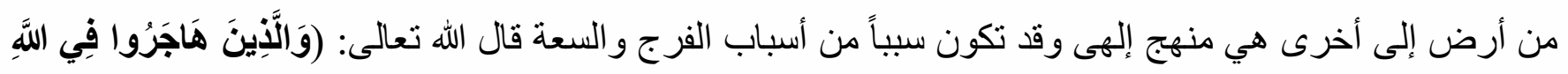

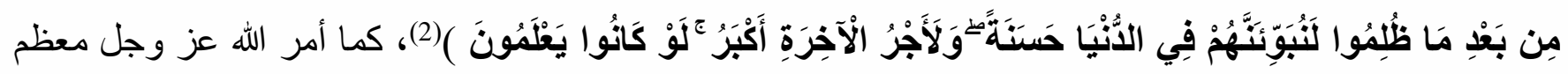

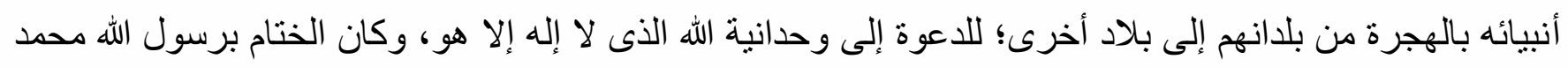

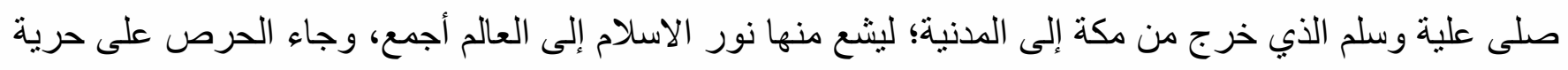

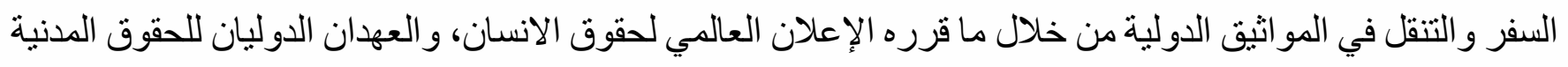
و السياسية، و اللذان أكدا على أن لكل فرد حرية التنقل واختيار محل إقامته، وسارت على هذا النهج التشريعات الداخلية للاول؛ حيث تم التأكيد على تللك الحرية من خلال إدر اجها في صلب الدساتير ثم تقرير الضمانات اللازمة لها من خلال القو انين الجنائية.

إلا أن الو اقع العلمي أفرز العديد من المشكلات المتعلقة (بحرية السفر) الأمر الذى استدعى أن تكون تلك الحرية غير مطلقة، لأن الحرية المطلقة هي فوضى مطلقة - وبالتالي كان تدخل المشرع ليضع الحدود الفاصلة بين حرية

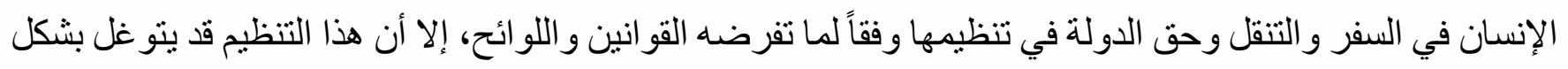
ما من حيث النصوص أو التطبيق إلى الحد الذى يجعله عائقاً بين الثخص وممارسته المشرو عة لحريته الثخصية،

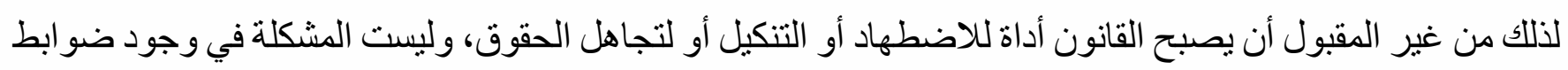

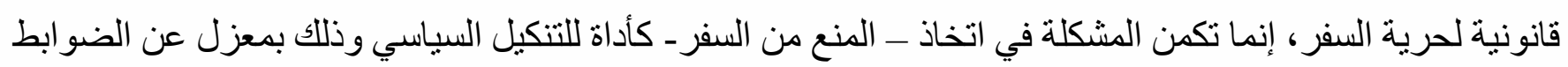
القانونية، من هنا برزت الحاجة لبيان المنع من السفر في المو اد الجنائية من خلال: 


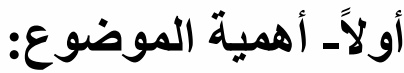

تتجلى أهمية البحث في محاولة معالجة المشكلات التي يثير ها البحث، والإجابة على التساؤلات التي تثيرها فرضياته، ذلك أنه لا خلاف على أهمية السفر بالنسبة إلى عموم البشر، و وأن تقييد حرية الإنسان في السفر لهو من أنثد

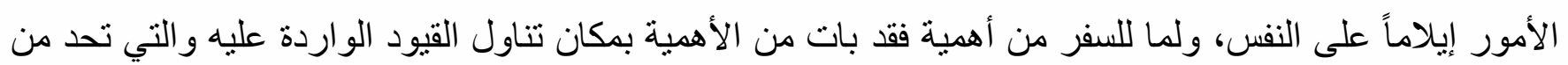
حرية ممارسته، وذللك بالر غم من تكفل الدستور بحماية تلك الحرية ومنع تقييدها إلا بأمر قضائي، في حين يؤكد الو اقع العلمي وجود العديد من الجهات الإدارية التي يمكنها منع المواطنين من السفر، ويأتي ذللك نتيجة تخلى المشرع العادي بـادي عن دوره في تنظيم هذا الموضوع تثريعياً، وما يستتبعه هذا الأمر من وصم جميع القرارات الصادرة من جهات غير مهري

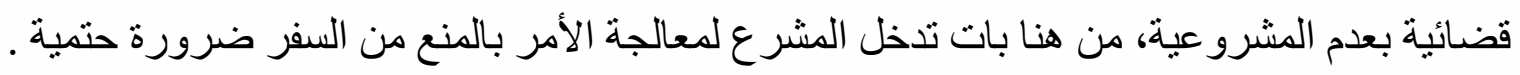

ثانياً_أسباب اختيار الموضوع: بهوم

يعتبر المنع من السفر أحد أكثر القيود مساساً بالحرية الثخصية؛ لما ينتج عنه من مساس مباشر بحرية التنقل وبالعديد من الحريات الأخرى، كالعمل و التعلم و العلاج، بل ويمس حرية ممارسة الثعائر الدينية، فالممنوع من السفر لا يستطيع الذهاب إلى الأماكن الدينية المقدة خار جدولته. ويعد السفر من أسمى الحريات الثخصية لدى عموم البشر،

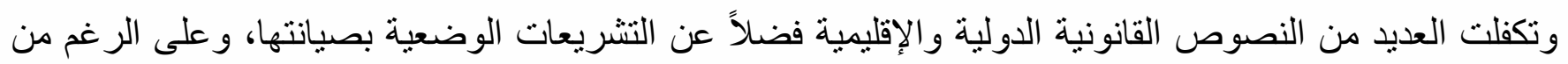
الاهتمام على الصعيدين الدولي والمحلي بحرية السفر والتنقل، وبالرغم من مساس إجراء المنع من السفر بالحرية

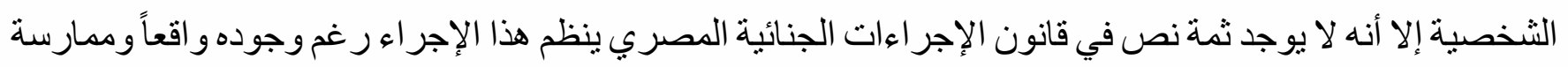
من هنا كانت الحاجة ملحة للتعرض لهذا الموضوع، كما أن حداثة تنظيم إجر اء المنع من السفر في بعض القو انين

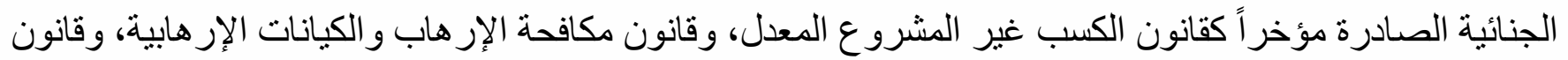
مكافحة جر ائم تقنية المعلومات كان حافز اً قوياً دفعني للخوض في هذا الموضوع.

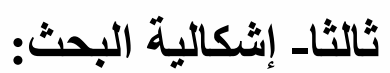

تكمن إثكالية البحث في ضوء إفصاح المشرع الدستوري المصري بعدم فرض قيود على حرية السفر إلا بأمر قضائي مسبب ولمدة محددة وفي الأحوال المبينة في القانون، إلا أن المشرع المصري لم يلتزم بما جاء في الدستور

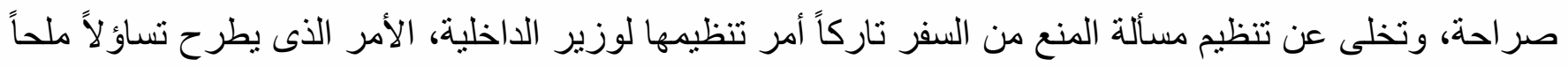
حول مدى مشروعية أوامر وقرار ات المنع من السفر الصادرة بالمخالفة للنص الدستوري؟ ومع لزوم المنع من السفر

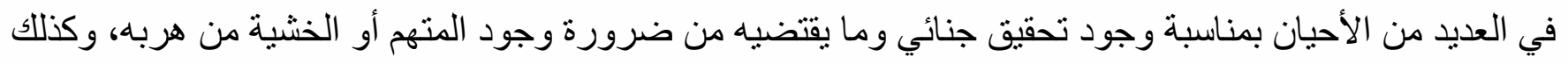


قد يكون الدافع وراء قرار المنع من السفر هو صيانة أمن المجتمع، وبالتالي قد يصدر من جهات غير قضائية بالمخالفة

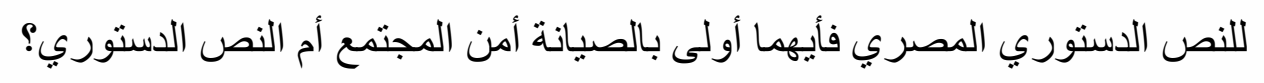

و عقب صدور حكم المحكمة الدستورية العليا المصرية بعدم دستورية نص المادنين (8، 11) من القانون 97 لسنة 1959 بشأن جوازات السفر فيما تضمناه من تفويض وزير الداخلية في تحديد شروط منح جواز السفر وتخويله سلطة رفض منح جو از السفر أو تجديده وكذا سحبة بعد إعطائه أثثر تساؤل حول مدى صلاحية النص الدستوري الوارد بالمادة (62) من الدستور المصري الحالي للتطبيق في موضوع المنع من السفر بمعزل عن تدخل المشرع لتنظيم هذا

\section{رابعا- منهج البحث:}

تتسم حرية السفر بالتعقيد؛ نظر اللتنخل في حرية ممارستها من جانب السلطة التنفيذية ممثلة في وزير الداخلية، الأمر الذى يتطلب قدرا كبيرا من التنظيم ودقة في الكيفية التي تمارس فيها تلك الحرية، بشكل يوضح حدود هذه بهنه

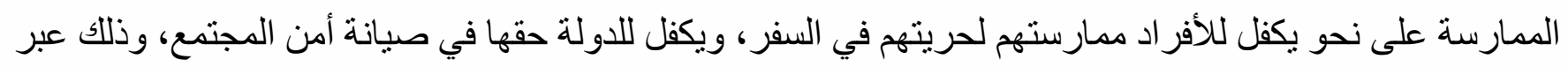
فرضها المنع من السفر كقيد على حرية التنقل والسفر، وبالتالي اتبعت في هذه الدر اسة عدة مناهج: المنهج الوصفي

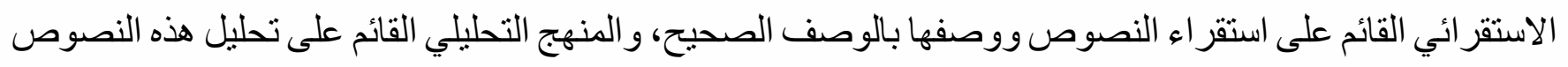
وموضو عاتها، ثم المنهج الاستنباطي، لاستخلاص القو اعد التي تعالج موضوع البحث، وكذلك اعتمدت على المنهج المقارن بين النظام القانوني المصري وبعض النظم القانونية الأجنبية والعربية مستأنسا قدر الإمكان بالأحكام القضائية

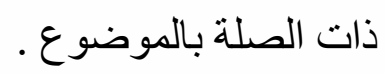

خطة البحث:

المقدمة

المبحث الأول: ماهية المنع من السفر وصوره في المواد غير الجنائية ومشروعيته المطلب الأول: مفهوم المنع من السفر.

• المطلب الثاني: صور المنع من السفر في غير المواد الجنائية.

• المطلب الثالث: مشروعية المنع من السفر وطبيعته القانونية.

المبحث الثاني: الإطار الثرعي والقانوني لحرية السفر والقيود الواردة عليه .

• المطلب الأول: حرية السفر في الثريعة الإسلامية والقيود الواردة عليها . • المطلب الثاني: حرية السفر ومشرو عية المنع منه في المو اثثي الدولية والإقليمية. المطلب الثالث: حرية السفر والمنع منه في التشريعات الوطنية. 


\section{محمد السعبد القز عة}

المبحث الثالث: صور المنع من السفر في الدعوى الجنائية .

• المطلب الأول: المنع من السفر في قانون الكسب غير المشروع ـ .

• المطلب الثاني: المنع من السفر في تتريعات مكافحة الإرهاب.

• المطلب الثالث: المنع من السفر في قانون مكافحة جر ائم تقنية المعلومات.

المبحث الرابع: الأحكام الإجرائية للمنع من السفر في المواد الجنائية.

• المطلب الأول: الجهات المنوط بها المنع من السفر.

• المطلب الثاني: تنظيم إدر اج الأشخاص الممنوعين من السفر و الرفع منها .

• المطلب الثالث: التظلم من الإدر اج على قو ائم الممنوعين من السفر . 


\section{المبحث الأول}

ماهية المنع من السفر وصوره في المواد غير الجنائية ومشروعيته

تمهيذ وتقسيم:

ينبغي في البداية لبيان المنع من السفر في المواد الجنائية أن أوضح مفهومه، و التمييز بين المنع من السفر كإجر اء جنائي وبين المنع من السفر في القو انين الأخرى غير الجنائية،و التعرف على مشرو عيته وطبيعته القانونية

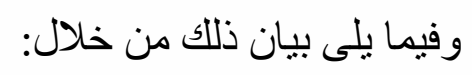

\section{• المطلب الأول: مفهوم المنع من السفر.}

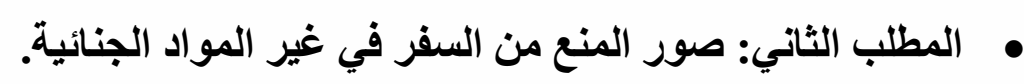

• • المطلب الثالث: مشروعية المنع من السفر وطبيعته القانونية.

المطلب الأول

مفهوم المنع من السفر

المنع من السفر عبارة عن مركب لغوي من مصطلحين المنع والسفر فما هو المنع وما هو السفر؟ ثم ما هو المنع لغن من السفر كمركب لغوي؟ هذا ما سأسعى إلى تلمس إجابة مرضية حوله من خلال بيان:

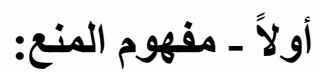

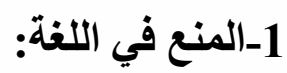

يقال منعه الثيء منعاً حرمه إياه، ويقال منعه من حقه، وامتتع الثيء تعذر الحصول عليه، و عن الثيء: كف

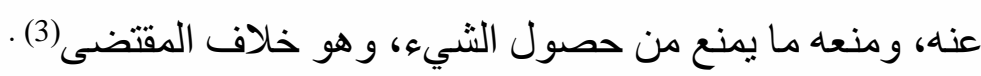
2-المنع في الاصطلاح: لم يتعرض الفقهاء بتعريف لمصطلح (المنع) إلا أن استعمالهم له لم يخرج عن المدلول اللغوي، ويقصد به

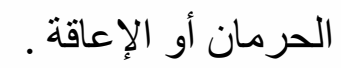
ثانيا - تعريف السفر:

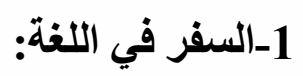




\section{محمد السعبد القز عة}

هو مصدر مشتق من الفعل (سفر)، فقد جاء في أساس البلاغة سفر، سافر ، سفرا بعيداً، وبيني وبينه مسافر بعيد،

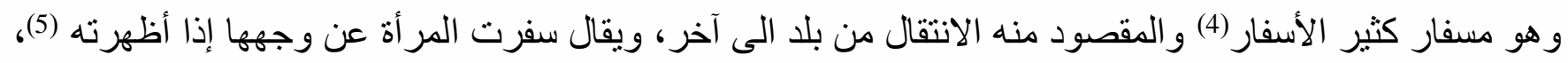

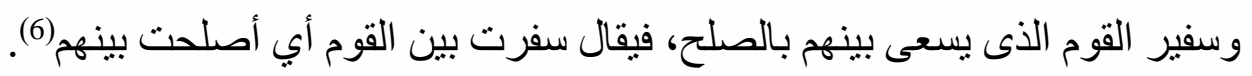

(4) أساس البلاغة، أبي القاسم جار محمود بن عمر بن احمد الزمخشري، تحقيق محمد باسل، الطبعة الاولى، دار الكتب العلمية، بيروت،

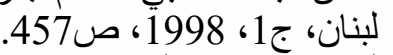

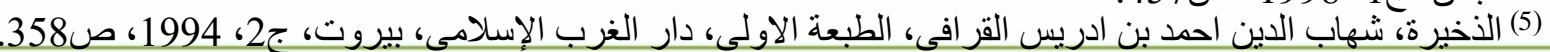

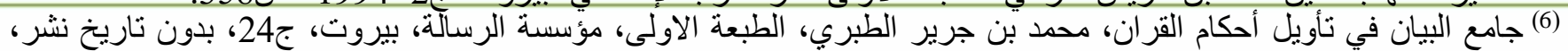


هو الخروج عن محل الإقامة بقصد مسيرة ثناثة أيام وسط من ذلك المحل (7)، وجاء في تعريفه بأنه هو الخروج على قصـد مسـيرة ثلاثة أيام ولياليها فأكثر بسـير الإبل ومشـى الأقدام (8)، ويلاحظ أن المقصـود من تللك التعاريف هو السـفر المتعلق بالأحكام الثــر عية من جواز قصــر الصــلاة، و إباحة الإفطار في نهار رمضــــان ... إلخ من الأحكام الثـر عية المتعلقة بالسفر ، غير أن هذا التعريف لا ينسجم مع العصر الحالي وذلك لتطور الحياة، وتنتوع وسـائل النقل

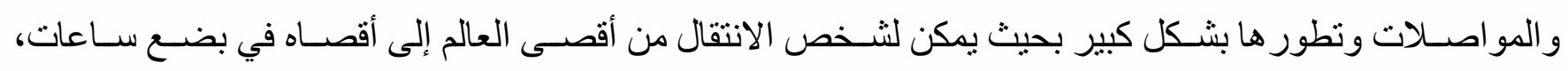
و الأنسب أن يرجع في تحديد ما يعد سفر وما لا يعد كذللك إلى العرف السائد في كل مجتمع . 3-السفر في القانون:

يعرف السفر قانوناً بأنه هو (مغادرة الأفراد طواعية من دولة المواطن قاصدين الدخول في إقليم دولة أخرى

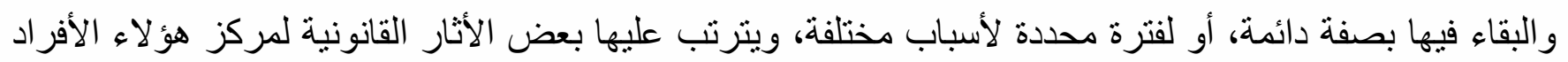

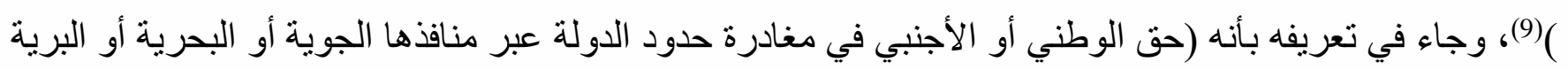

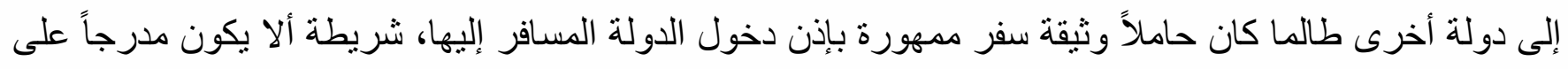
قو ائم المنع من السفر)(10)، بينما حرية السفر هي حرية كل شخص في التنقل داخل حدود الدولة وخارجها، وحريته في مغادرة بلده و العودة إليها منى شاءع (11). ثالثا ـ المنع من السفر كمصطلح مركب: كعادة القو انين دائما لا تتعرض إلى تعاريف ناركة بذلك المجال للفقه و الثر اح؛ لأنه من غير المستحسن تصدي المشرع للتعاريف فعرف المنع من السفر بأنه (منع الثخص، أو الثيء من مغادرة حيز مكاني معين، أو اقليم معين أو منطقة معينه )(12)، ويؤخذ على هذا التعريف أنه لم يحدد الجهة مصدرة قرار المنع بالسفر، كما لم يبين الأسباب

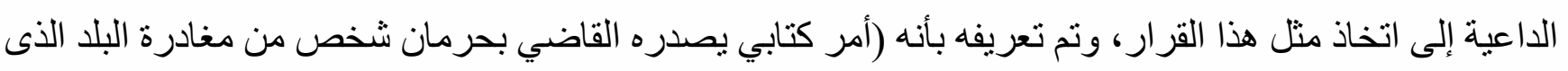
يعيش فيه، لسبب معين، حتى تنقض أسباب هذا المنع )(13)، وتم تعريفه بأنه (عدم السماح بالانتقال من موضع الإقامة

(7) التقرير و التحبير على التحرير في اصول الفقه، ابن امير الحاج، تحقيق عبدالله محمود، دار الكتب العلمية، بيروت، لبنان، الطبعة|لاولى،

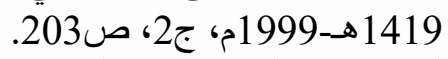
(8) التعريفات، على بن محمد الجرجاني، تحقيق مجمو عة من العلماء، الطبعة الاولى، دار الكتب العلمية، بيروت، لبنان، 1403هـ، 1983م،

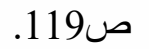

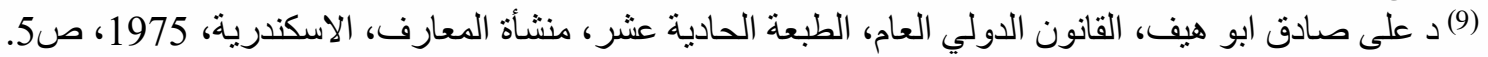

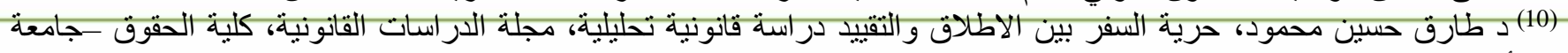

(11) Le Tribunal des conflits 9 juin 1986.

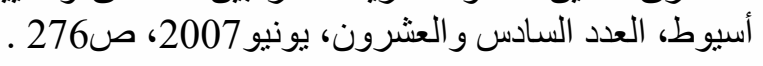

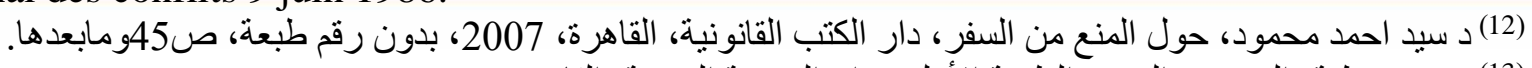

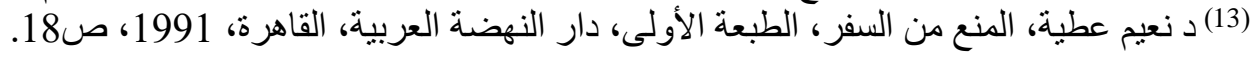




\section{محمد السعبد القز عهة}

إلى مكان آخر لأغر اض مخصوصة)(14)،وجاء في تعريفه بأنه (رفض الإدارة الترخيص بالسفر لكل شخص يرغب في مغادرة إقليم الدولة، لوجود وقائع صحيحة تدينه تمنح الإدارة المختصة الحق في منعه من السفر) (15). و على صعيد التعريف القضائي للمنع من السفر عرفته المحكمة الإدارية العليا بأنه (إجر اء تفرضه طبيعة الغايات

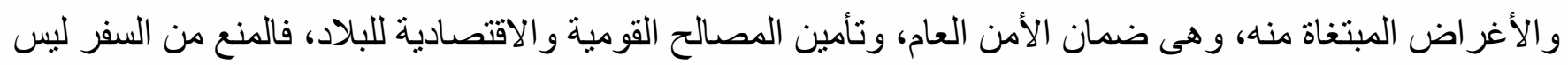
عقوبة جنائية يتعين أن يتحقق الاتهام بيقين ويثبت ثبوتا لاشك فيه، إنما هو عبارة عن إجراء وقائي موقوت بتحقيق

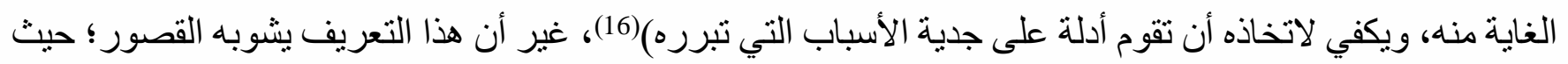

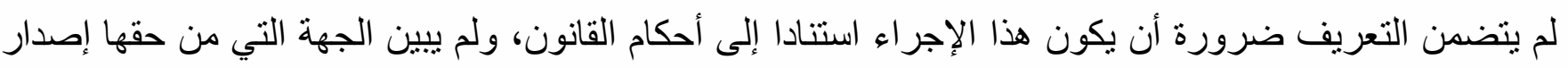

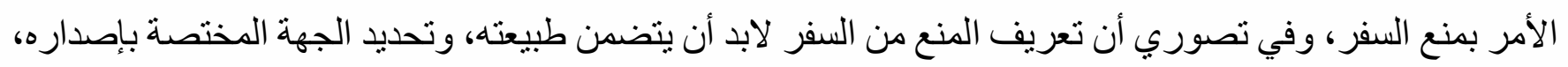
و الضمانات القانونية لصيانة الحق في السفر وذللك في إطار الثر عية الدستورية. أما المنع من السفر كإجر اء جنائي فعرفته محكمة النقض المصرية بأنه (من الإجر اءات الجنائية التي تباثر ها

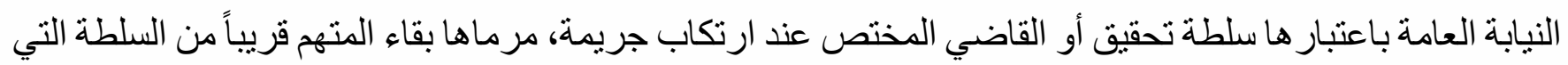
تباثر التحقيق والمحافظة على أدلة الاتهام، وهي بهذه المثابة أعمال تحقيق لها طبيعة قضائية، وقيام جهة الإدارة بتنفيذها لا ينظر إليه بمعزل عن هذا الأمر، وليس من شأنه أن يغير وصفه باعتباره صادر اً من السلطة القضائية)(17).

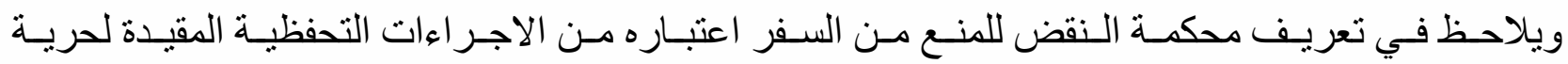

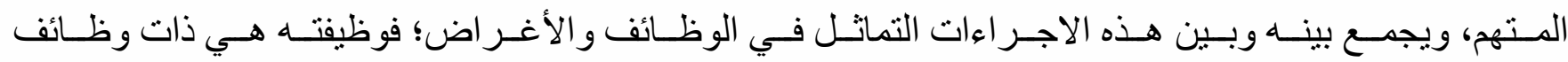

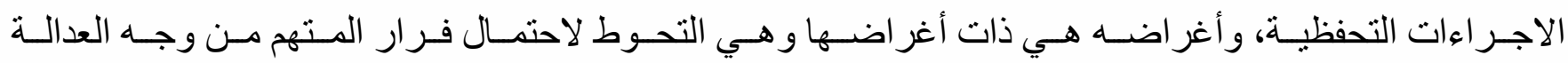

\section{رابعاً: أنواع المنع من السفر:}

وفقاً لما سبق من تعاريف للمنع من السفر فقد بات جلياً بأن المنع من السفر ليس مقصور اً على الأشخاص دون

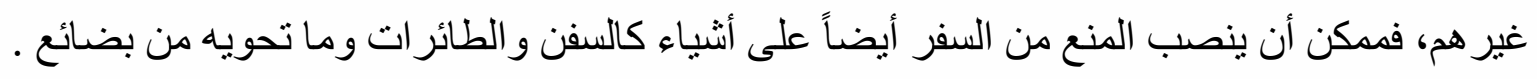

(14) د محمد عثمان شبير، منع المدين من السفر في الفقه الإسلامي، مجلة دراسات العلوم الانسانية، الاردن، العدد الثاني، مجلد22، 1997،

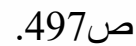
(15) د احمد جاد منصور ، الحماية القضائية لحقوق الانسان، دراسة خاصة في حرية التنقل و الاقامة في القضاء الإداري المصري، دائة دراسة

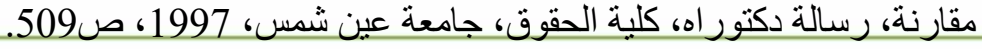

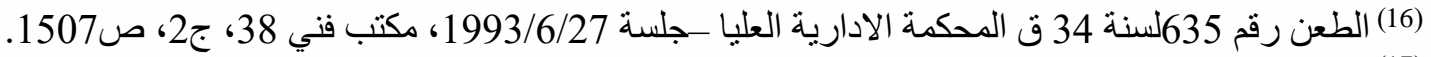
(17) نقض جنائي، الطعن رقم (18) د نبيل مدحت سالم، شرح قانون الاجر اءات الجنائية، دار النهضة العربية، القاهرةج، 2، 2009، بدون رقم طبعة، ص1347. 


\section{محمد السعبد القز عة \\ 1-المنع من السفر الوارد على الأشياء:}

يقصد بمنع السفر للأثياء هو منع مغادرتها البلاد إلا بأمر من السلطة المختصة، وقد ينصب هذا المنع على سفينة أو طائرة، أو بضائع على متن تللك السفن والطائرات محل المنع من السفر، وقد يكون قرار المنع ناجما عن جريمة جنائية أو إخلال بالتز ام قانوني أو تعاقدي حسب الأحوال(19)، وليس بالضرورة أن يكون المنع من السفر بالنسبة للسفن و الطائر ات نتيجة جريمة أو إخلال بالتز ام قانوني فمن الممكن أن برجع قرار المنع إلى عيب فني أو عطل في السفينة

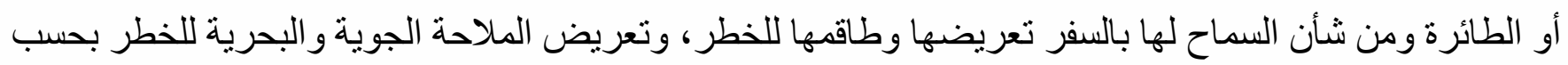

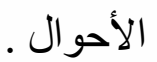

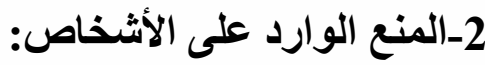

منع الأشخاص من السفر يقصد به منع الثخص من مغادرة إقليم الدولة أي عدم مغادرة حدودها، وقد يكون المنع من السفر في المو اد المدينة كمنع المدين من السفر قبل حصول الدائن على حقه المدعي به إذا قامت أسباب جدية تؤكد إمكانية فرار المدين قبل سداد الحق المدعى به، أو منع من السفر في مسائل الأحوال الثخصية كالمناز عات حول سفر الزوجة إلى الخارج، كما قد يكون المنع من السفر في المواد الجنائية، ويعد في هذه الحالة إجر اءا تحفظيا تتخذه السلطة المختصة من شأنه منع فرار المتهم في المسائل الجنائية .

\section{المطلب الثاني}

\section{صور المنع من السفر في غير المواد الجنائية}

تتنوع صور المنع من السفر من منع وارد في المو اد الجنائية، وآخر وارد في غير المو اد الجنائية كمنع الأشخاص من السفر في المو اد المدنية والتجارية، وكذا المنع من السفر الوارد بقانون الأحوال الثخصية على الأشخاص، ودئ وفيما يلي بيان ذلك من خلال:

\section{أولاًـ المنع من السفر في المواد المدنية والتجارية:}

الأصل هو عدم المساس بالحرية الثخصية للمدين، وبالتالي عدم جواز الإكراه البدني في المسائل المدنية و التجارية في الثريعة الإسلامية و القانون الوضعي كقاعدة عامة، ولكن هناك استثناء ينص على أنه يجوز أن يمنع من السفر المحكوم عليه الصادر ضده حكم غيابي بناء على طلب المدعي بالحق المدني في شكل عريضة إلى قاضي الأمور الوقتية، وذللك إلى حين إعلانه بالحكم الغيابي الصادر ضده، وذللك مر اعاة للحقوق النهائية للمدعي بالحق المدني التي تترتب بالحكم الجنائي الصادر ضد المطلوب الأمر بمنعه من السفر (20)، لذلك لقاضي الأمور الوقتية أن يأمر بمنع المتهم بـاهي

(19) د عبدالرحيم بن سيف بن على القصابي، الإكر اه البدني (در اسة تحليلية لحبس المدين ومنعه من السفر في كل من القانونين العماني

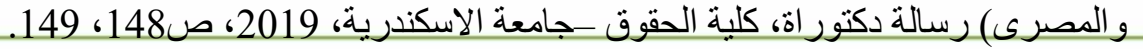
(20) المستشار /مصطفي مجدى هرجة، الاو امر على عر ائض ومناز عتها التنفيذية، دار الثقافة للطباعة والنشر والتوزيع، 1982، ص19. 


\section{محمد السعبد القز عة}

من مغادرة البلاد مؤقتاً إلى حين إعلانه بالحكم الغيابي، وفي ذلك أمر قاضي الأمور الوقتية بمحكمة جنوب القاهرة الابتدائية بمنع المعروض ضده من السفر إلى خارج البلاد لحين إعلانه بالحكم الجنائي الغيابي الصادر ضده بناء على لئ طلب المدعي بالحق المدني(21).

إلا أن بعض النظم المقارنة تجيز المنع من السفر في المسائل المدنية كمنع المدين من السفر فقد جاء في المادة 297 من قانون المر افعات الكويتي(22) بأن (للائن بحق محقق الوجود حال الأداء ولو قبل رفع الدعوى الموضو عية أن يطلب من مدير إدارة التنفيذ أو من تندبه الجمعية العامة للمحكمة الكلية من الوكلاء بالمحكمة إصدار أمر بمنع المدين

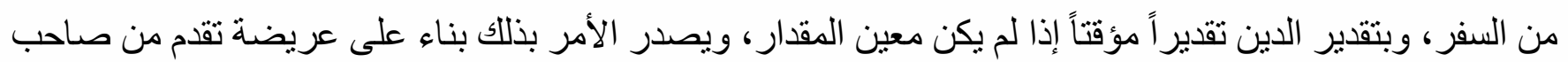
الثأن لإدارة التنفيذ إذا قامت أسباب جدية تدعو إلى الظن بفر ار المدين من الدين رغم ثثوت قدرته على الوفاء ...........) وفي قانون الإجر اءات المدنية و التجارية العماني(23) قررت المادة 427 بأن (للمحكمة في أب مرحلة من مر احل الدعوى بناء على طلب المدعي، أن تأمر بمنع المدعى عليه من السفر خارج السلطنة إذا قامت أسباب جدية يخشى معها فراره وكان الحق المدعى به معلوماً مستحق الأداء غير مقيد بشرط ولا تقل قيمته عن خمسمائة ريال، مالم يكن نفقة شر عية .......) وجاء في المادة 428 من ذات القانون بأنه (يستمر أمر المنع من السفر سارياً حتى ينقضي التزام المدين قبل دائنه الذي استصدره وتأمر المحكمة بسقوطه في الأحوال الآتية ..........). لكن في مصر لا يوجد منع مدين من السفر؛ يرجع ذللك إلى أن معظم الأنظمة القانو نية اللاتينية ومن بينها النظام المصري تقوم على أساس الفلسفة الفردية، والتي تعلي من قيمة الحرية الثخصية وتقوم على صبانتها وحمايتها، ويعود ذلك عدم جو از ممارسة الإكر اه البدني على الأشخاص منذ عام 1867م، و الذى ألغى الحبس في المو اد المدنية التجارية، وبالتبعية إلغاء منع المدين من السفر لكونه أحد وسائل الإكر اه البدني على الأشخاص (24).

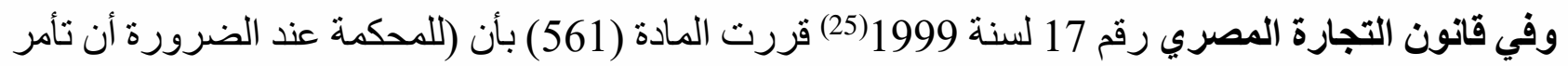
باتخاذ الإجراءات اللازمة للتحفظ على الثخص المدين، ولا يجوز للمحكمة أن تأمر بهذا الإجراء في حكم إثهار الإفلاس، إذا طلب المدين إنثهار إفلاسه خلال الميعاد المشار إليه في الفقرة الأولى من المادة 553 من هذا القانون)،

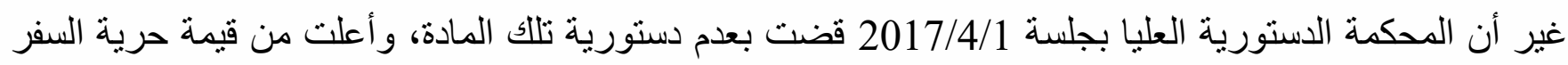
وقالت في حكمها بعدم دستورية صدر البند 2المادة 561 إذ تجيز التحفظ على شخص المحكوم عليه بإنشهار إفلاسه، ولو بحكم غير نهائي، دون أن يكون متهم بإفلاس بالتدليس أو بالتقصير، فإنها تنطوي على تلى تقييد للحرية الثخصية،

$$
\begin{aligned}
& \text { (21) أمر وقتي } 116 \text { لسنة } 1982 \text { جنوب القاهرة جلسة، 1980/1/31. }
\end{aligned}
$$

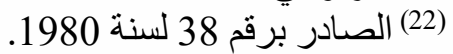

$$
\begin{aligned}
& \text { (23)رقم } 29 \text { لسنة } 2002 \text { الصـادر في } 6 \text { مارس } 2002.17 .
\end{aligned}
$$

(24) J. Vincent et J. Prévault, Voies d'exécution et procedures de distribution, 17e éd, No.17, p. 17. 


\section{محمد السعبد القز عة}

بغير انتهاج الوسائل القانونية التي كفلها الدستور، دون الالتزام بالقيود و الضوابط الدستورية، التي تحكم تعزيز أب من الإجر اءات المقيدة للحرية وأصولها وفقاً لنص المادتين 54، 92 من الدستور، بحسبان إطلاق رخصة الحكم بالتحفظ على شخص المدين المفلس يعد تقييدا لحريته، دون جرم قارفه على نحو يعطل حق المشمولين به في النفاذ إلى ألوان

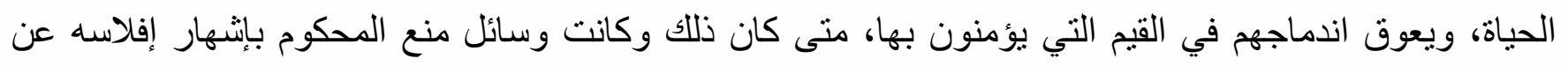
الإضرار بمدينه تجد مشروعيتها الدستورية في كل إجراء يكفل حماية هذه الحقوق، دون أن يسنطيل إلى المساس بالحرية الثخصية للحككوم بشهر إفلاسه إلى حد مصادرتها، كما هو الحال في التحفظ على شخصها، المقرر في جرائم

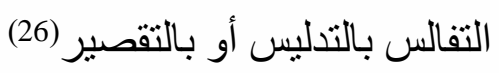
ثانياً ـ المنع من السفر في الأحوال الثخصية: قررت المادة الأولى من القانون رقم (1) لسنة 2000 بإصدار قانون تنظيم بعض أوضاع وإجر اءات التقاضي في مسائل الأحو ال الثخصية بأنه (تسري أحكام القانون المرفق على إجراءات التقاضي في مسائل الأحوال الثخصية و الوقف، ويطبق فيما لم يرد بشأنه نص خاص فيه أحكام قانون المر افعات المدنية و التجارية و أحكام قانون الإثبات في

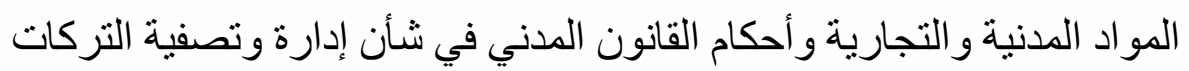

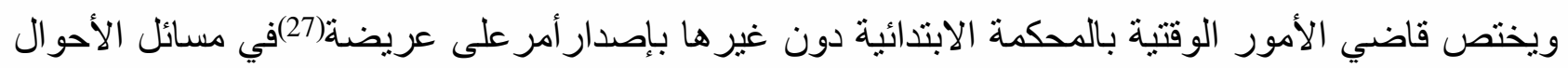

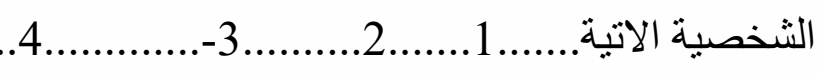

5ـ المناز عات حول السفر إلى الخارج بعد سماع أقو ال ذوي الثأن )، ووفقاً لنص المادة فقد اختص قاضي الأمور

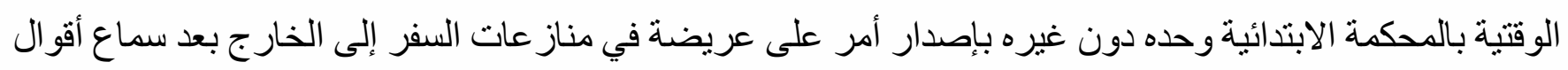
ذوي الثأن، و هذا الاختصاص الأخير هو الذى نص فيه على أن القاضي لا يصدر أمره إلا بعد سماع أقو ال ذوي الثنأنه

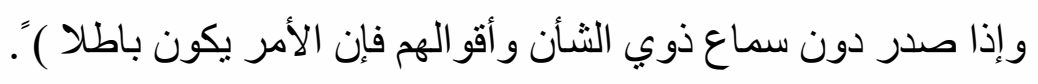

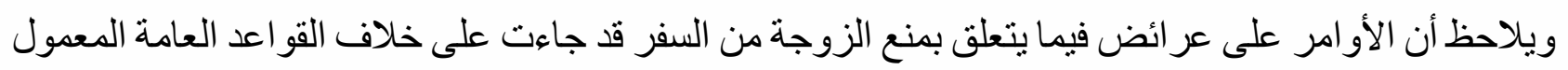
بها في الأو امر على عر ائض من حيث الاختصاص النوعي؛ فالمحكمة المختصة بنظر مباثرة الزوجة لحقوقها ونها ومنها

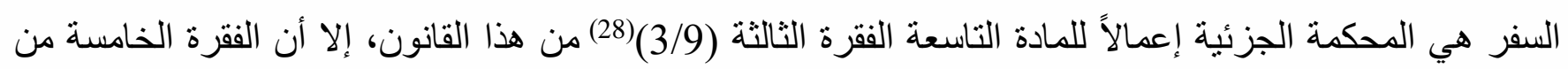

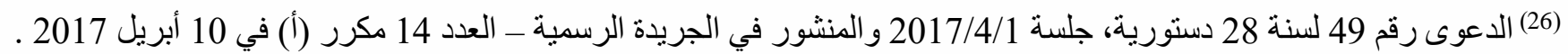

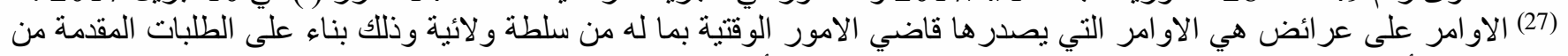

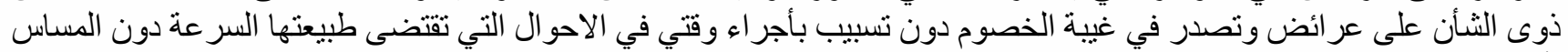

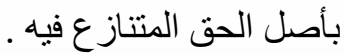

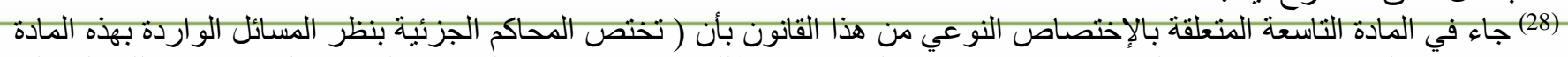

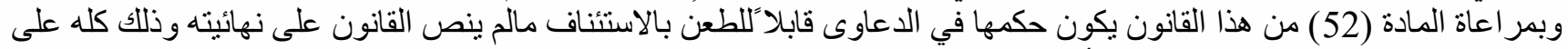

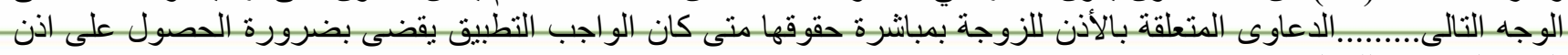


المنع من السفر في المواد الجنائية

\section{محمد السعبد القز عة}

المادة الأولى من هذا القانون حصرت اختصاص قاضي الأمور الوقتية بالمكمة الابتدائية دون غيره بنظر مناز عات

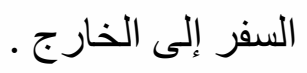

إلا أنه لا يفهم من ذلك أن النص القانوني يبيح للقاضي أن يصدر أمر على عريضة بتمكين الزوجة من السفر

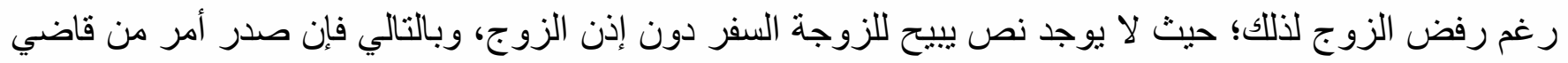
الأمور الوقتية بالسماح للزوجة بالسفر دون موافقة زوجها كان الأمر باطلاً؛ لأن الأوامر الصادرة بتقييد الحريات

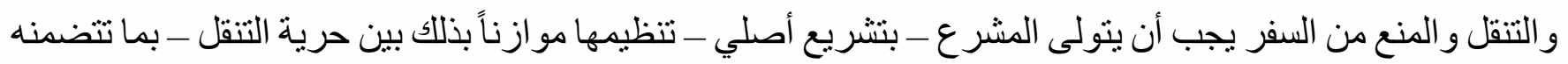
من الحق في مغادرة الوطن و العودة إليه - وبين حقوق الدولة و أفر اد المجتمع، دون إخلال بأحكام الثريعة الإسلامية

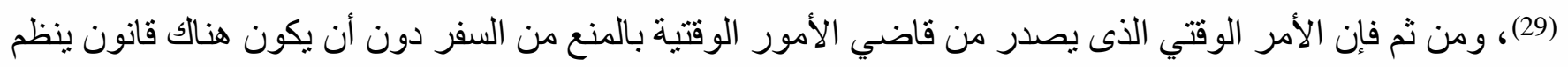

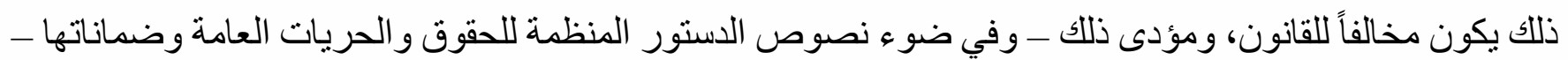
أن أو امر المنع من التتقل والسفر أو تقييد الحرية بأي قيد هي إجراءات جنائية تمس الحرية الثخصية التي لا يجوز تنظيمها إلا بقانون صادر من السلطة التشريعية وليس من سلطة أخرى بناء على تفويض و لا بأداة أدنى مرتبة من

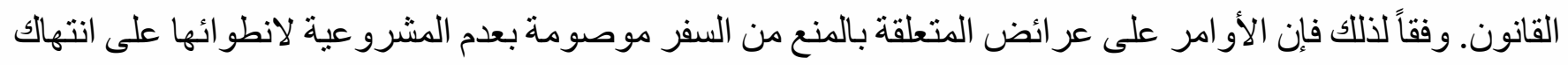
خطير لحرية السفر ، و هو من الحريات الأساسية اللصيقة بالإنسان، ومخالفتها لأحكام الدستور باعتباره القانون الوضعي

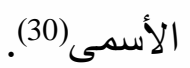

ومن جانبي أتصور أنه في ظل الغياب التشريعي المنظم لسفر الزوجة دون إذن زوجها، فإني مع الر أي الفقهي المنادي بأن يكون المرجع في تلك الحالة لأرجح الأقوال في مذهب الإمام أبي حنيفة والذى خلص إلى إلى (عدم مبارحة

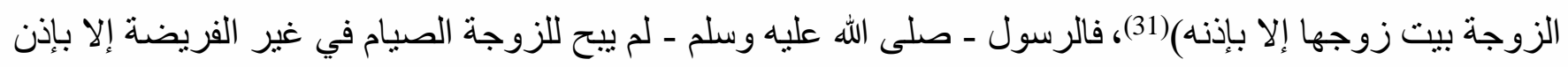

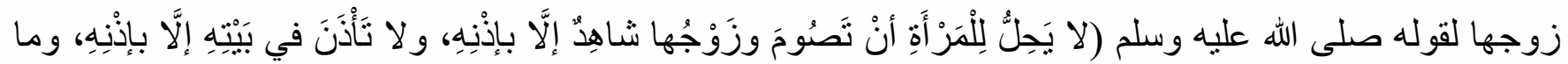

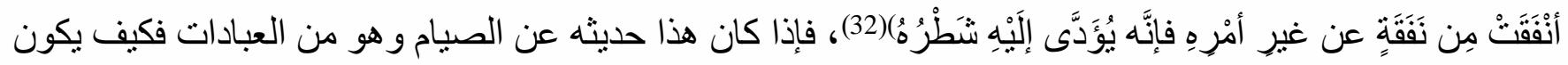

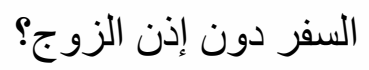

\section{المطلب الثالث}

\section{مشروعية المنع من السفر وطبيعته القانونية}

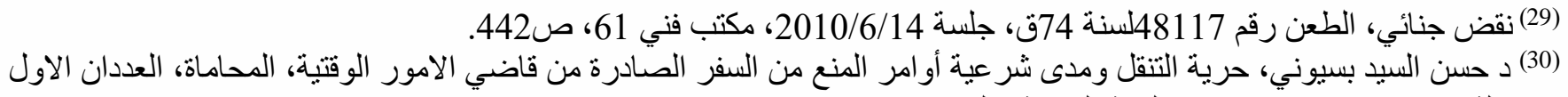

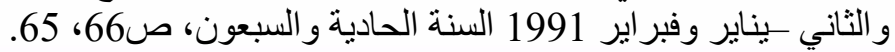

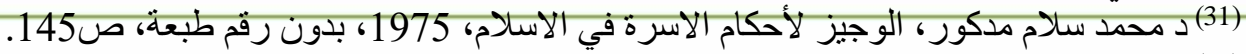

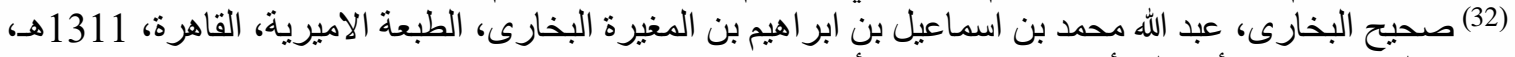

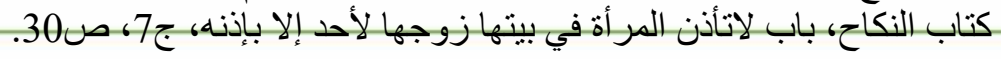




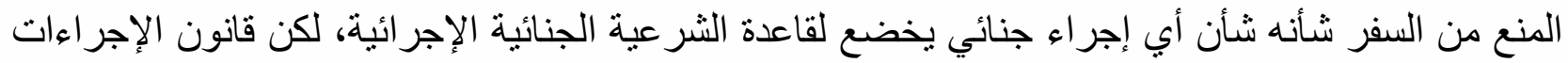

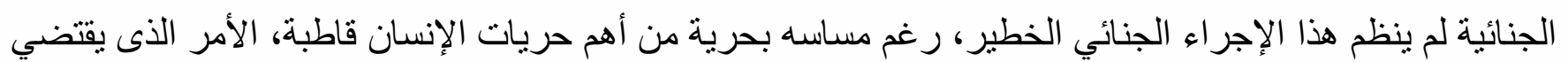
معا بيان مشروعية المنع من السفر وطبيعته القانونية .

\section{الفرع الأول}

\section{مشروعية المنع من السفر}

يعتبر حق السفر من الحريات المهمة التي تكلتت النظم القانونية بصيانتها ور عايتها نتيجة لعديد من الأسباب منها

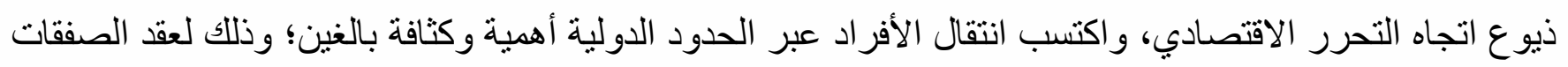

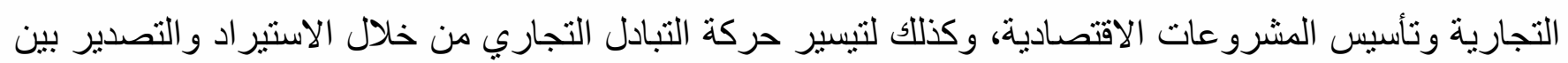
مختلف الدول، وتبرز أهمية السفر أيضا من خلال اتساع ظاهرة تدويل العمالة خصوصاً مع انتثار الثركات متعددة

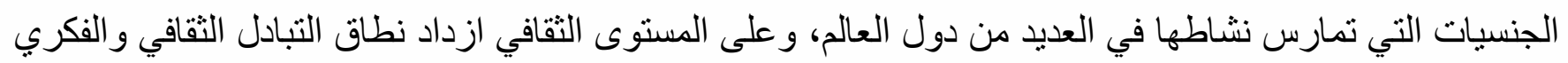

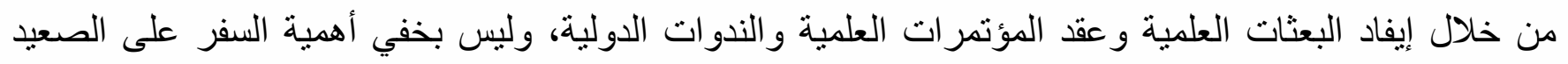

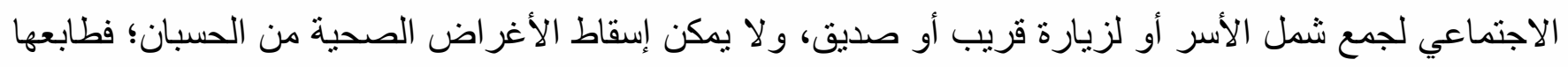

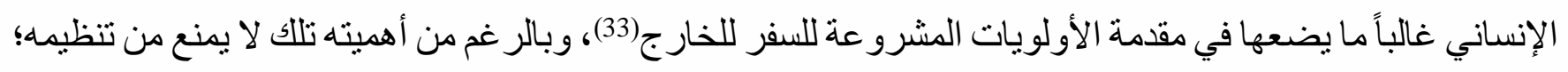

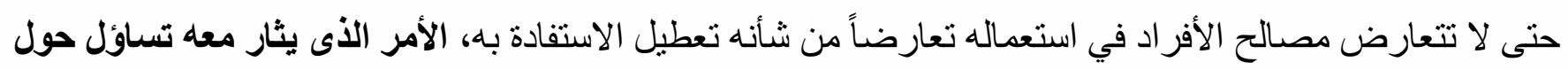

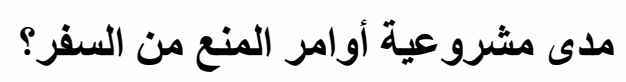
تأتى الإجابة على هذا التساؤل بأن السفر شأنه شأن العديد من الحريات التي تخضع في تنظيم ممارستها للمصلحة العامة، فيجوز تنظيم ممارسة هذا الحق بوضع بعض القابة القيود عليه، بقصد الدحافظة على الأمن العام وسلامة الدولة

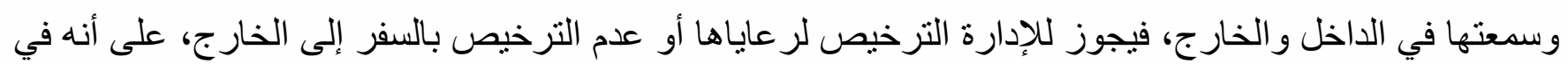

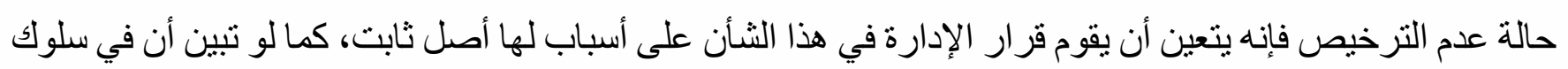

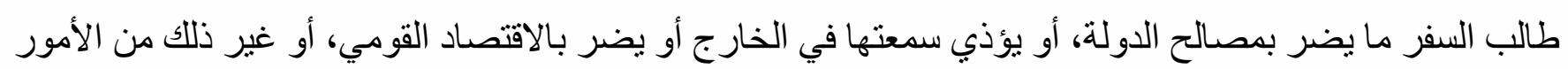

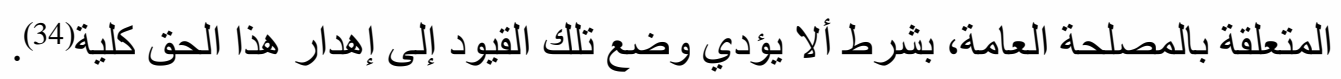

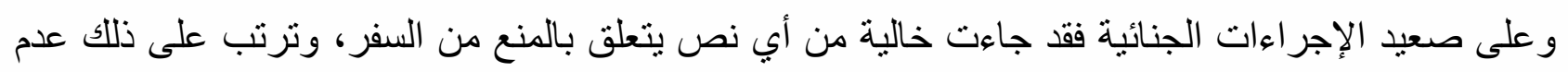
مشرو عية القرار ات الصادرة من النائب العام أو قاضى النحقيق كإجر اءات احتياطية؛ وذلك لأفتقار ها لأى سند قانوني،

(33) د عبدالتو اب معوض الثوربجي، المنع من السفر كإجر اء جنائي ـمقارناً بالحبس الاحتياطي، و الرقابة القضائية في التشريع الفرنسي-

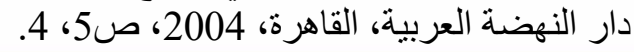

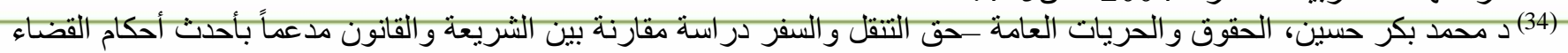

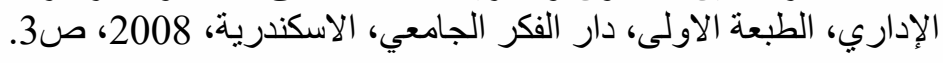




\section{محمد السعبد القز عة}

و لا يعد إجر اء تحقيق ولو كان صادراً بشأن تحقيق جنائي، خصوصاً وأن الإجر اءات الجنائية تحكمها قاعدة الثر عية الجنائية ومفادها أن لكل إجر اء جنائي سنده من القانون، و الذى يبدو جليا عدم وجوده في قانون الإجر اءات الجنائية(35)، و هو ما جعل العديد من الفقهاء يؤكدون على مخالفة القرار الوز اري 54 لسنة 2013 بشأن الإدر اج على قو ائم الممنو عين من السفر للدستور ويصمه بعدم المشرو عية؛ إذ سمح بتقييد الحرية الثخصية بمنع السفر من خلال تحديد الجهات التي لماتي يحق لها طلب الإدر اج على قو ائم الممنو عين من السفر بالنسبة إلى الأشخاص الطبيعيين، وهو ما لا يجوز إلا بقانون .

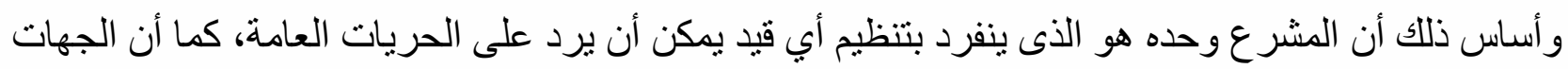

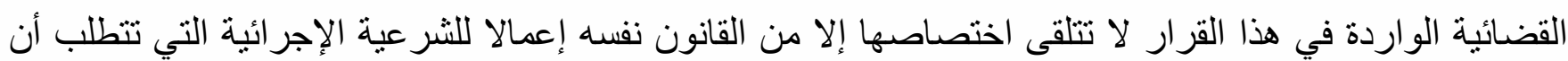
يكون القانون هو مصدر الإجراءات الجنائية(36)، لذلك لا يكتسب قرار تقييد الحرية - مثل المنع من السفر - صفة لهائ الإجراء الجنائي إذا استند إلى لائحة إدارية؛ لأنه في هذه الحالة ينحدر إلى الأعمال الإدارية، ولا يتمتع بصفة العمل

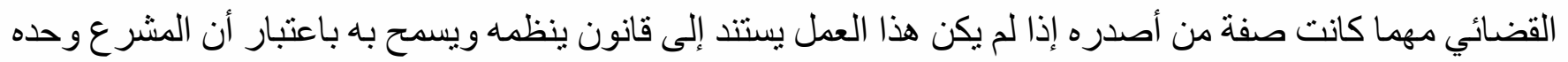
ينفرد بتنظيم كل ما يتعلق بالحقوق و الحريات(37). تأكيداً لللك قضت محكمة النقض بأن (حق المو اطن في الانتقال يعكس ر افداً من رو افد حريته الثخصية التي حفل بها الدستور، دالاً بذلك على أن حرية الانتقال تتخرط في مصاف الحريات العامة، وأن تقييدها دون مقتضى مشروع إنما يجرد الحرية الثخصية من بعض خصائصها، ويقوض صحيح بنيانها. وقد عهذ الدستور إلى السلطة التشريعية دون غير ها بتقدير هذا المقتضى ولازم ذلك أن يكون الأصل الحرية والاستثناء هو الدنع، وأن المنع من التنقل لا يملكه إلا قاض أو عضو نيابة عامة يعهد إليه القانون بذللك دون تدخل من السلطة التنفيذية، وقد حفل الدستور بالحقوق المتصلة بالحق في التنقل، وجاءت المادة 52 منه لتؤكد على حق المواطن في السفر ومغادرة البلاد، ومقتضى ذلك أن الدستور لم يعقد للسلطة التنفيذية اختصاصا بتنظيم شيء مما يمس الحقوق التي كفلها الدستور فيما تقدم، وأن هذا التنظيم يتعين أن تتو لاه السلطة التشريعية بما تصدره من قوانين.

وجرى قضاء المحكمة الدستورية العليا على أنه إذا ما أسند الدستور تنظيم حق من الحقوق إلى السلطة التشريعية فلا يجوز لها أن تتنصل من اختصاصها وتحيل الأمر برمته إلى السلطة التنفيذية، فإذا ما خرج المشرع على ذللك وناط بالسلطة التنفيذية تنظيم الحق من أساسه كان متخلياً عن حقه الأصيل المقرر بالدستور ساقطاً. بالتالي- في هوة مخالفة (القانون) ب(38).

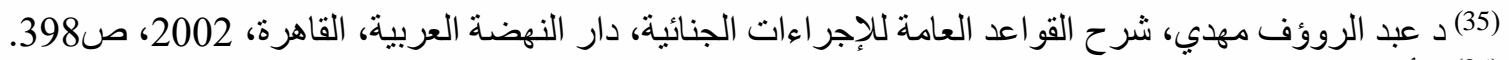

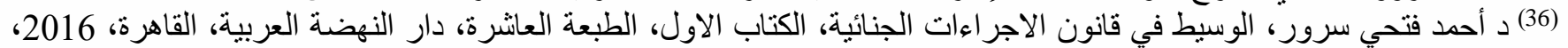




\section{محمد السعبد القز عة}

وتأكيداً لذلك الاتجاه قضت محكمة جنايات قصر النيل في القضية المعروفة إعلاميا بتمويل منظمات المجتمع المدني برفع أسماء المتهمين من قو ائم الممنو عين من السفر وجاء في قرار ها (ومن حيث أن العدالة معصوبة العينين لا تفرق بين أحد وآخر، وأن من بطأ أرض جمهورية مصر العربية له ذات الحقوق والوجبات؛ حتى بعلم من يفد إليها بحقوقه وواجباته تدعيماء لتقة من يقدم إليها مو اطناً أو أجنبياً في عدالة الدولة دون أن يتعرض لأمور فجائية لا يدرك كنهها، و لا يوجد قانون ينظمها مما يزيد الثقة في عدالة الدولة، ومن حيث أنه لما كان ما تقدم وكان البادي من الأوراق أن القرار الصادر بإدر اج اسم المتظلمين على قو ائم الممنوعين من السفر قد صدر من قاضي التحقيق، وبالتالي يكون هذا القرار ليس له سند قانوني، ويكون تقييد حرياتهم في التنقل التي جعلت المساس بحرية التنقل منوط بإصدار قانون ينظم ذلك من السلطة التشريعية بما يكون قرار منع المتظلمين من السفر قد افتقر إلى السند القانوني مما يتعين معاه إلغاء

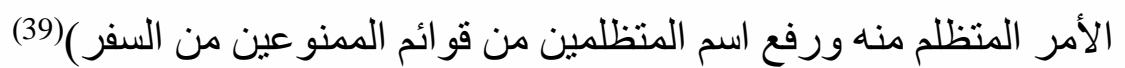

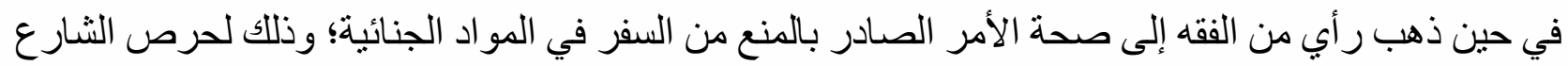
في حالة الإفر اج المؤقت التحوط لعدم هرب المتهم إلى الخارج، و لا يقدح في ذللك عدم النص عليه في قانون الإجر اءات الجنائية في النصوص المتعلقة بالحبس الاحتياطي؛ وذللك لأن وجود المفرج عنه في متناول يد المحقق أو المحكمة شرط للإفر اج عنه، فإذا أخل بهذا الثرط جاز الأمر بإعادته إلى محبسه، و إذا كان السفر الذى هو قرين الهرب موجباً لإعادة الحبس الاحتياطي فمن المقبول أن يكون المنع منه شرطاً للإِفراج عن المتهم المحبوس، وفضلا عن ذللك فإن المادة 144 من قانون الإجراءات الجنائية المصري توجب تعهد المتهم بالحضور كلما طلب، وبألا يفر من تتفيذ الحكم الذي يمكن أن يصدر ضده، وكان السفر ينطوي على إخلال بهذا التعهد مما يؤكد صحة الأمر بالمنع من السفر (40)، ويعزز

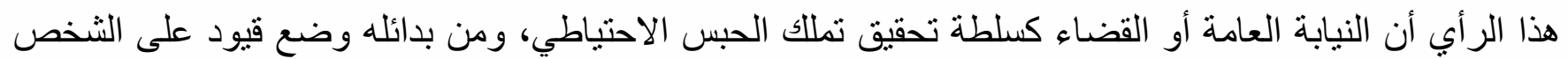
تضمن عدم هروبه من المحاكمة، ومن تللك القيود إلز ام المتهم بالإقامة في مكان معين أو تقديم نفسه إلى جهات التحقيق متى طلب منه ذللك. وبالتالي جرى العمل على أن يصدر النائب العام قراره بالمنع من السفر كبديل للحبس الاحتياطي باعتبار أن من يملك الأكثر يملك الأقل (41)، إلا أن من الفقهاء من ذهب إلى عدم صحة الاستناد إلى خضوع المتهم لإجر اء الحبس الاحتياطي للقول باختصاص النيابة العامة بإصدار أو امر المنع من السفر خثية هروبه بعد الإفر اج عنه، 


\section{محمد السعبد القز عة}

فلكل من الإجر اعين نظامه وخصائصه وطبيعته و آثاره المختلفة مما لا يجوز معه الخلط بينهما التزاماً بمبدأ الثر عية الجنائية(42).

ومن جانبي فإني أؤيد الاتجاه الفقهي القائل بعدم مشرو عية المنع من السفر؛ لأنها إجر اء يتصف بالجسامة وينطوي على تقييد بالغ لحرية التنقل، التي هي أحد أهم الحريات الأساسية المنصوص عليها في الدساتير ، و لا يوجد في قانون الإجر اءات الجنائية المصري نص يمنح سلطة التحقيق إصدار الأمر بمنع مواطن من السفر، و لا يقال أن للمحقق أن

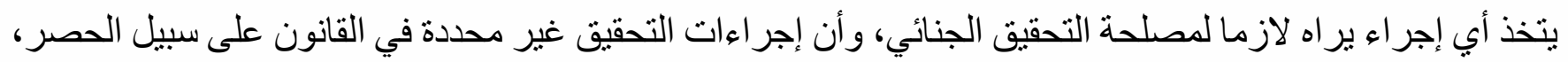
فهذا القول مردود عليه بأن الإجر اءات الجنائية لاسيما تلك المقيدة للحقوق و الحريات الواردة في الدستور تخضع لقاعدة الشر عية الإجر ائية ومقتضاها طبقا للنصوص الدستورية أن كل إجر اء لابد أن يكون له سنده القانوني، فالدستور لا يبيح

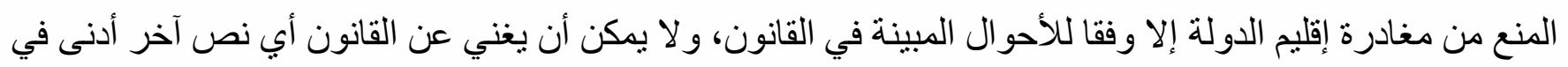

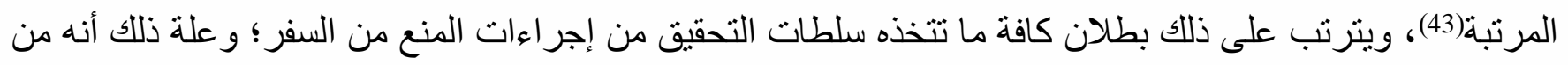
الأصول المقررة أنه لا قياس في الإجراءات الماسة بالحرية الثخصية، فلا يجوز قياس هذا الإجر اء على غيره من

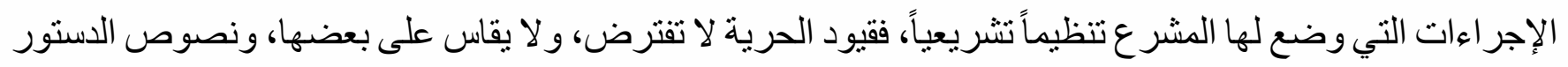
واضحة في وجوب أن بنص القانون عليها(44). و لا يغير من ذلك قرار وزير الداخلية بشأن تنظيم الممنوعين من السفر ، ولا التعليمات الصادرة للنيابة العامة في هذا الثأن؛ إذ هما في مدارج التشريع أدنى من الدستور ، بل أدنى من القانون ويعتبر كلاهما منسوخاً ضمناً بقوة الدستور

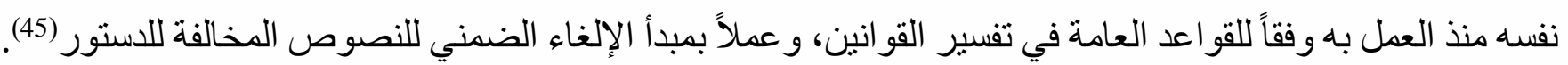

\section{الفرع الثاني}

\section{الطبيعة القانونية للمنع من السفر}

تختلف الطبيعة القانونية لقرار المنع من السفر باختلاف الجهة طالبة الإدراج، فإن كانت من الجهات القضائية

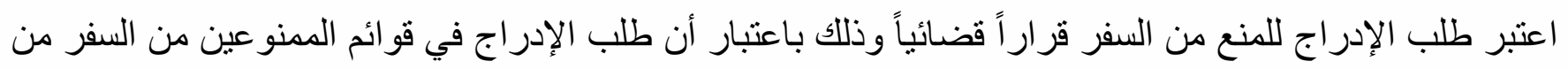

(42) د فاضل نصر الله، الحق في التنقل وشرعية أو امر النيابة العامة من السفر (در اسة مقارنة)، مجلة الدراسات القانونية، كلية الحقوق،

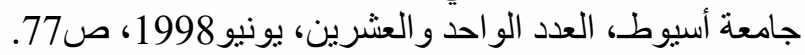

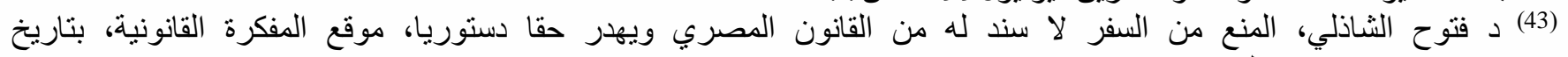

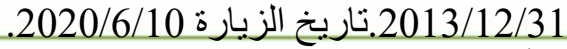

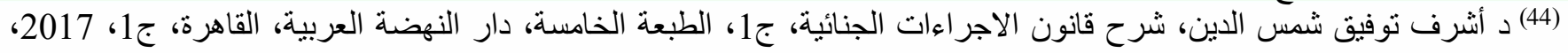




\section{محمد السعبد القز عة}

ضمن الإجراءات التحفظية والتي تستند للمادة 208 مكرر(أ)(46) من قانون الإجر اءات الجنائية المصري والتي جاء فيها (في الأحو ال التي تقوم فيها من التحقيق أدلة كافية على جدية الاتهام في أبي من الجر ائم المنصوص عليها في الباب

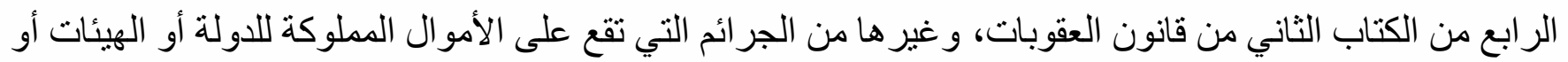

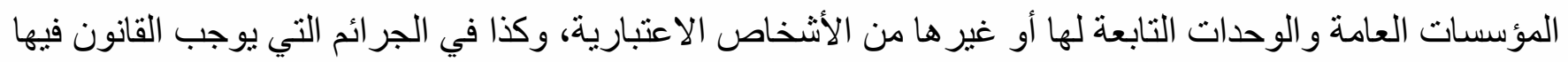
على المحكمة أن تقضي - من تلقاء نفسها - برد المبالغ أو قيمة الأشياء محل الجريمة أو تعويض الجهة المجنى عليها

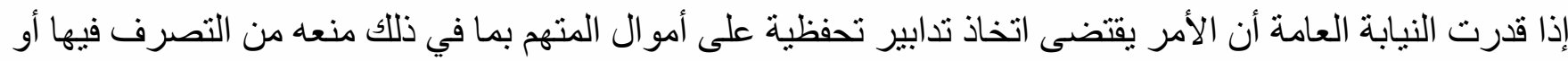

أما إذا كان طلب الإدر اج من الجهات التنفيذية فالقرارات الصادرة في هذا الثنأن هي قرار ات إدارية تستند في صدور ها إلى التدابير المنصوص عليها في المادة 162لسنة 1958بشان حالة الطو ارئ وما قررته المادة الثالثة من هذا القانون (لرئيس الجمهورية متى أعلنت حالة الطوارئ أن يتخذ التدابير المناسبة للمحافظة على الأمن العام والنظام العام وله على وجه الخصوص .

1- وضع قيود على حرية الأشخاص في الاجتماع و الانتقال و الإقامة و المرور في أماكن أو أوقات معينة........) و على ذللك يكون لرئيس الجمهورية أو من يفوضه بعد ذللك أن يضع القيود على حرية الأشخاص في الاجتماع و الانتقال و الإقامة، وذلك دون التقبد بأحكام قانون الإجر اءات الجنائية(47)، وطالما هي قرارات صادرة من جهات تنفيذية واعتبار ات قرار ات إدارية فهي تخضع لرقابة القضاء الإداري لذلك استقر القضاء الإداري على أن (التدابير التي تتخذ طبقا للأحكام العرفية سواء أكانت تدابير فردية أو نتظيمية ليست إلا قرارات إدارية يجب أن تتخذ في حدود القانون ويتعين أن تخضع لرقابة القضاء )(48). وفي تقديري أنه من غير المقبول الإفر اط بمنح تفويضات تضع قيودا على حرية

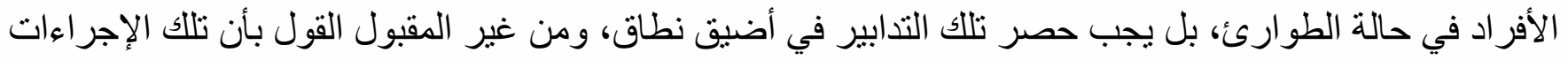
التي يتم اتخاذها تخضع لرقابة القضاء؛ لأنه من غير المستساغ تحمل الثخص ولوج الثخص طريق التقاضي لإلغاء التدبير المتخذ ضده ومقيداً لحريته الثخصية على غير سند من القانون. وذهب ر أي آخر إلى وصف قرار ات الإدر اج على قو ائم الممنوعين من السفر بأنها قرارات إدارية، ويعزو ذلك إلى أن الجهات المشار إليها في القرار الوزاري المعني (فقط تطلب ولا تصدر قرار بذلك)، و إنما يصدر القرار التنفيذي بالإدر اج على القو ائم من وزير الداخلية أو يفوضه في هذا الأمر، ولذللك ينعقد الاختصاص لمحاكم مجلس الدولة ـ دون

(46) المادة مضافة بالقانون رقم 43/120/20/نة 1967ومستبدلة بالقانون 174 لسنة 1998، والمنشور بالجريدة الرسمية العدد (51) مكرر في 1998/12/20

(47) أمجدى عرفة احمد، أوامر وقرارات المنع من السفر(دراسة عملية)، المجموعة المتحدة للطباعة والنشر، مصر ، بدون رقم طبعة

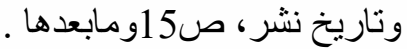
(48) محكمة القضاء الإداري -الحكم رقم 568لسنة 3، جلسة 1952/6/30، مكتب فني 6 رقم الجزء 3- ص1266. 
غير ها - بنظر الطعون على قرار ات الإدر اج على قو ائم الممنوعين من السفر، حيث إن حق التنقل و السفر يتعين تنظيمه وفقاً للدستور بما يحقق سلامة الدولة في الداخل و الخارج(49).

وتأكيدا على أن المنع من السفر قرار إدارى بحسب هذا الر أى جاء حكم دائرة توحيد المبادئ بمجلس الدولة بأن (المحكمة شيدت قضاءها فيما يتعلق بالدفع المبادئ بشأن اختصاص المحكمة على أساس أن نعت القرار المطعون فيه بأنه قر ار قضائي أمر يخالف طبائع الأمور، ذللك أن اتصال المحكمة الجنائية بالدعوى لا يكون إلا بعد تصرف النيابة العامة في التحقيقات، ويستحيل عملاً قياس حالة المنع من السفر أو الادر اج من النيابة العامة، وهو عمل محض إداري لهري بما يصدر عنها من أوامر بالحبس الاحتياطي التي نظمها المشرع وبين طرق الطعن فيها، ومن ثم فإنه إزاء الطبيعة الإدارية لقرارات النائب العام بالمنع من السفر والإدراج يكون القضاء الإداري صاحب الاختصاص بمراقبة مشرو عيتها، بالإضافة إلى وجود فر اغ تشريعي لتنظيم المنع من السفر بعد صدور حكم المحكمة الدستورية العليا بجلسة 2000/11/4 في القضية رقم 243 لسنة 21 ق دستورية، وبالتالي فإن ما يصدر من قرار ات تتعلق بالمنع من السفر أيا كانت سلطة من أصدر ها يخضع لرقابة المشرو عية التي يباشر ها القضاء الإداري لوزنها بميزان القضاء الذي يهدف

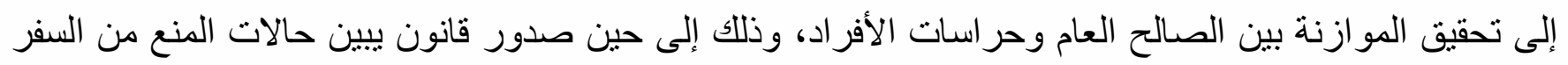
وشروطه و إجر اءاته ........... فلهذه الأسباب حكمت المحكمة باختصاص مجلس الدولة بهيئة قضاء إداري بالفصل في الدعاوى التي تقام طعنا على القرار ات الصادرة من النيابة العامة بالمنع من السفر (50) و على النقيض تماماً من حكم دائرة توحيد المبادئ بمجلس الدولة المصري، جاء حكم الدائرة الأولى بالمحكمة بألمانه الإدارية العليا والذي جاء فيه أن (القرار الصادر من النائب العام بمنع متهم من السفر بمناسبة التحقيقات التي تجريها النيابة العامة باعتبار ها سلطة ناط به القانون مهمة التحقيق و المحافظة على أدلة الاتهام، وهو بهذه المثابة يعد عملاً من أعمال التحقيق التي تتسم بالطبيعة القضائية، ومن ثم تكون جهة القضاء العادي، وقد ناط بها المشر ع اختصاص الفصل في الدعاوى الجنائية، هي المختصة بنظر المناز عات التي تثار بشأن تلك القرار ات؛ ذللك أن هذه القرار ات قد صدرت في شأن مناز عة جنائية باعتبار ها تتصل بجريمة من الجر ائم التي تدخل في اختصاص جهة القضاء العادي، ومن ثم فإن هذه الجهة بحسبانها الجهة صاحبة الو لاية العامة بالفصل في جميع المناز عات و الجر ائم عدا ما تختص به محاكم

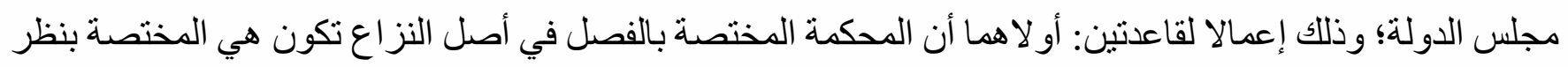
ما يتفرع عنه من مناز عات، ثانياً أن تحقيق العدالة تستوجب أن تكون المناز عة وما يتفر ع عنها بين جهة قضائية و احدة؛ جمعاً لأو اصر تللك المناز عة، وحرصاً على عدم تقطيع أوصالها بين جهات قضائية مختلفة، و لا ينال مما تقدم القول بأن

(49) د محمد أبوزيد محمد، الضوابط التظيمية للحريات العامة وضماناتها -حرية التنقل والاقامة، أكاديمية مبارك للأمن، مجلة كلية

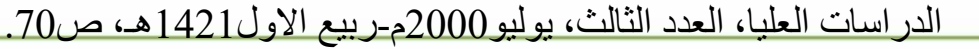

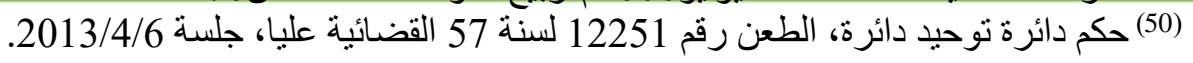




\section{محمد السعبد القز عة}

القرارات التي يصدر ها النائب العام بمنع المتهمين من السفر بمناسبة التحقيق معهم يعوز ها السند القانوني الذي ينظم هذه القرارات، ويحدد إجراءات الطعن عليها؛ ذلك أن تقاعس المشرع العادي عن إصدار تشريع ينظم إجراءات المنع

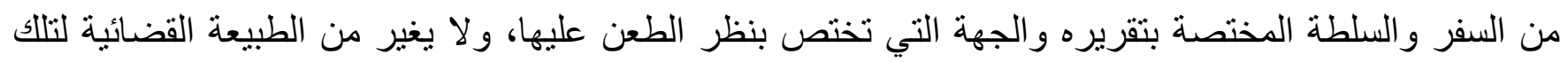
القرار ات، و لا يسو غحال إسناد الفصل في المناز عات التي تثير ها تللك القرار ات لمحاكم مجلس الدولة)(51). ولعل هذا الحكم الحديث يوضح عدم وجود نسق واحد يسير عليه قضاء مجلس الدولة المصري فيما يتعلق بإختصاصها بنظر قرارات المنع من السفر، فتارة يصف تللك القرارات بأنها إدارية، وأحياناً أخرى ينعتها بأنها ذات لهات

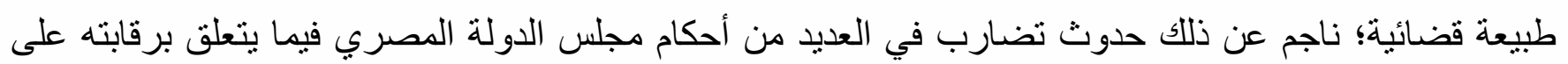
الأوامر و القرار ات الصادرة بالمنع من السفر.

وذهب رأي إلى القول بأن الطبيعة القانونية للأوامر والقرار ات الخاصة بالمنع من السفر لا تخرج عن طبيعة العمل القضائي بحال من الأحو ال، وذللك بافتر اض مشرو عيتها ودستوريتها خاصة من حيث الاختصاص بإصدار ها، وأن دور وزير الداخلية وتابعيه في هذا الصدد إنما هو وضع أوامر القضاء والنيابة العامة موضع التنفيذ من خلال وضع الممنوعين من السفر في قو ائم تعد لهذا الغرض ويتم توزيعها على كافة المنافذ التي يجوز السفر من خلالها؛

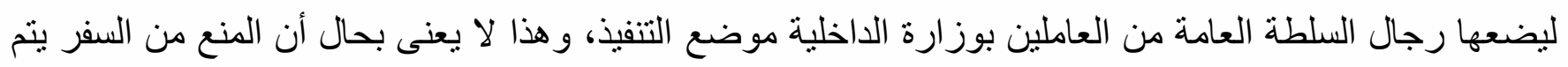

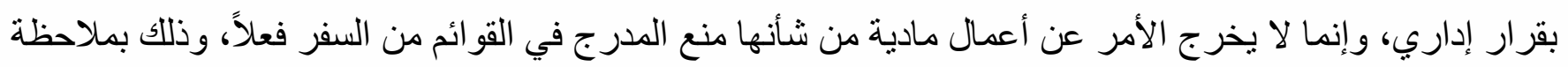

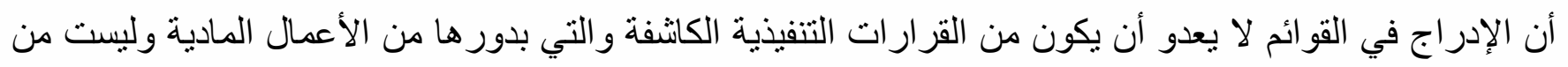

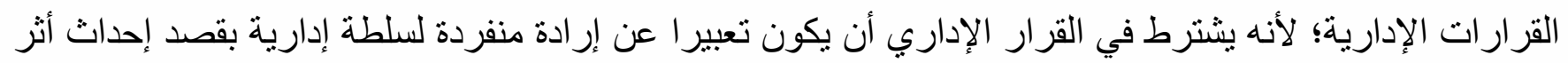
قانوني، و على ذلك فإذا لم يكن للعمل بذاته أثر قانوني يترتب على نفاذه بصفة نهائية، فإنه يدخل في عداد الأعمال المادية(52).

في حين أكدت المحكمة الدستورية العليا على الطبيعية القضائية لقرار المنع من السفر وبالتالي ينعقد الاختصاص بنظر ها للقضاء العادي (وحيث إن إجراءات التحقيق التي تتو لاها النيابة العامة بمناسبة ارتكاب جريمة جنائية تتميز

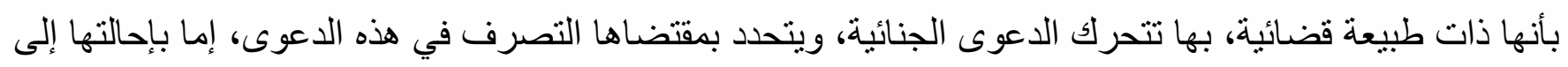
المحكمة المختصة، أو بألا وجه لإقاتتها، وكان القرار الصادر من النائب العام بمنع المتهمين من السفر بمناسبة

(51) حكم الدائرة الأولى - المحكمة الادارية العليا، الطعن رقم 202/75238 جلسة 2018/4/28 قبد النشر ، مشار إليه مجمو عة المبادئ التى

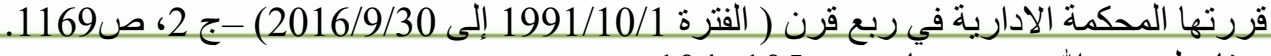

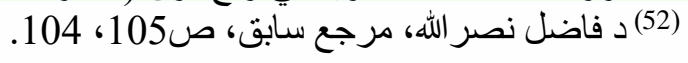




\section{محمد السعبد القز عهة}

التحقيقات التي تجريها النيابة العامة معهم يعد إجر اءً قضائياً من الإجر اءات التي تباثر ها النيابة العامة باعتبار ها سلطة ناط بها القانون مهمة التحقيق عند ارتكاب جريمة، وكانت الغاية من إصدار ذللك القرار هي بقاء المتهم قريب من السلطة التي تبانشر التحقيق والمحافظة على أدلة الاتهام، وهو بهذه المثابة يعد عملاً من أعمال التحقيق التي تتسم بالطبيعة القضائية، ومن ثم تكون جهة القضاء العادي - وقد ناط بها المشرع اختصاص الفصل في الدعوى الجنائية ـ هي المختصة بنظر المنازعات التي تثار بشأن تلك القرارات، ذلك أن هذه القرارات ـ وقد صدرت من النيابة العامة في شأن مناز عة جنائية ـ باعتبار ها تتصل بجريمة من الجرائم التي تدخل في اختصاص جهة القضاء العادي، فان هذه

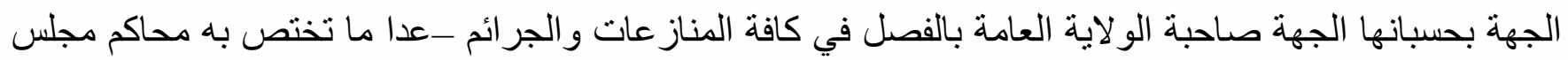
الدولة - تكون هي المختصة بنظر الطعن على هذه القرارات(53). وفي تقديري أن قرار المنع من السفر هو قرار إداري ولن يختلف باختلاف الجهة طالبة الإدراج سواء كانت جهة قضائية أو جهة تتفيذية؛ وذلك لأن أي من الجهات التي أوردها قرار وزير الداخلية رقم 2214 و المعدل بالقرار رقم 54 لسنة 2013 يقتصر دور ها على (طلب الإدراج ) في قو ائم الممنوعين، في حين أعطت المادة الثالثة من ذات القرار لمدير مصلحة وثائق السفر والهجرة والجنسية الحق في أن ينظر في طلبات القيد بقو ائم الممنو عين من مغادرة

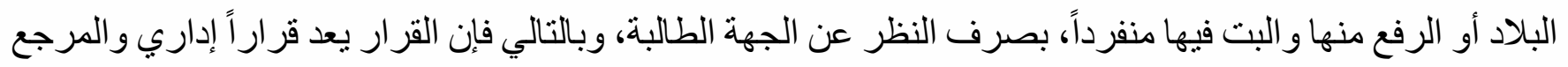
في تحديد أنه قرار إداري إلى السلطة التي أصدرته (رئيس مصلحة وثائق السفر والهجرة والجنسية ) والإجر اءات المتبعة في إصداره بغض النظر عن مضمونه وفحواه .

وبالتالي يحق له أن يعترض على أي طلب إدراج من الجهات المشار إليها في المادة الأولى من هذا القرار، كما

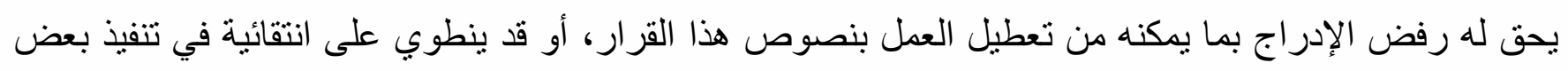

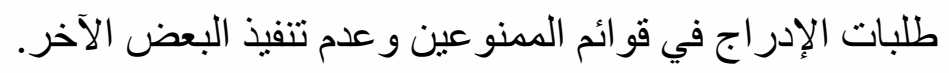
وبالتالي يكون التكييف القانوني لقرار المنع من السفر أنه قرار إداري صادين فيدر من وزير الداخلية يقبل الطعن عليه أمام القضاء الإداري حتى لو كان صـادراً بناء على طلب النائب العام طالما يخضع في النهاية لتقدير وزير الداخلية،

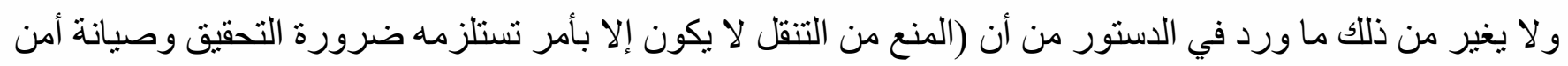

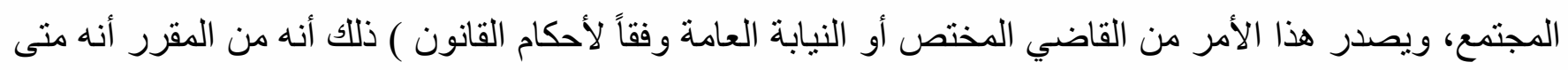

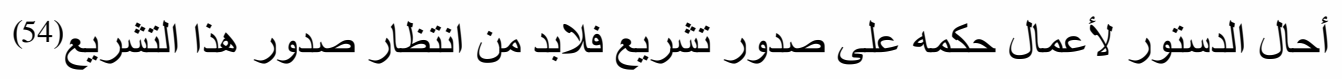




\section{محمد السعبد القز عة}

و عليه فإني أناثد المشرع بتدخل تشريعي بتنظيم إجراء المنع من السفر، على أن يكون قرار الإدر اج على قو ائم

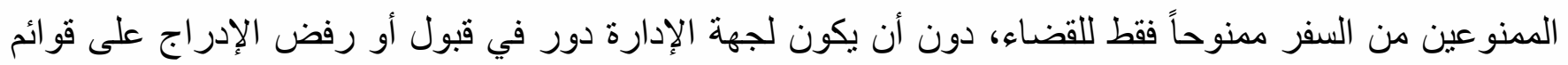
الممنو عين لتلافي أى تمييز أو تعسف من جانب الإدارة. 


\section{محمد السعبد القز عة}

\section{المبحث الثاني \\ الإطار الشرعي والقانوني للحق في السفر والقيود الواردة عليه}

تمهي⿻ وتقسيم:

عنيت الثريعة الإسلامية والقو انين و التشريعات الوضعية بإقر ار حق الإنسان في السفر كحق من حقوق الإنسان الأساسية، وارتباطه الوثيق مع العديد من الحقوق والحريات الأخرى، ويظهر ذلك جليا في تناول العديد من الآيات القرآنية و الأحاديث النبوية الثريفة للتأكيد على حق السفر، ولم تتخلف النظم القانونية الوضعية فى التأكيد على حق السفر، وذللك عبر العديد من المو اثيق الدولية والإقليمية، وكنللك في التشريعات الداخلية للدول وفيما يلي بيان ذللك من

خلال: - ال

المطلب الأول: حرية السفر في الثريعة الإسلامية والقيود الواردة عليها .

المطلب الثاني: حرية السفر ومشرو عية المنع منه في المو اثيق الدولية والإقليمية.

المطلب الثالث: حرية السفر و المنع منه في التشريعات الوطنية.

المطلب الأول

\section{حرية السفر في الثريعة الإسلامية والقيود الواردة عليها}

تعتبر حرية السفر في الثريعة الإسلامية أصلاً عاماً وأمر اً طبيعياً ملازماً للحياة، لا تحتاج إلى إقرار لممارستها بقدر ما تحتاج إلى تنظيم لتحقيق الهدف من تللك الممارسة (55)، وتأكيدا لذلك وردت العديد من الآيات الكريمة التي تؤكد

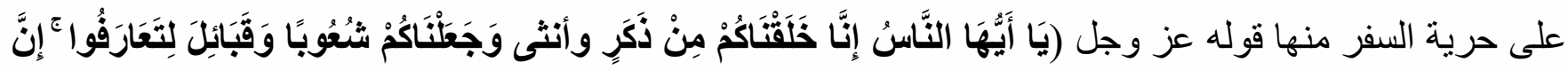

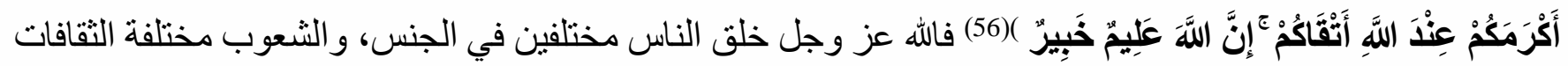
حتى يتم التعارف بينهم، و التعارف هنا يقصد به الاجتماعات المختلفة التي تتم من خلالها التلاقي و التعارف، وقد حث

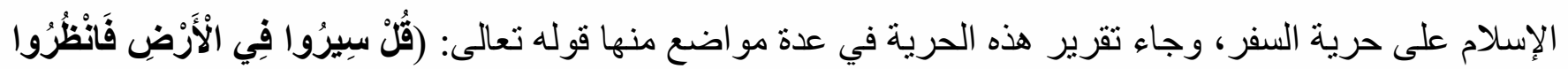

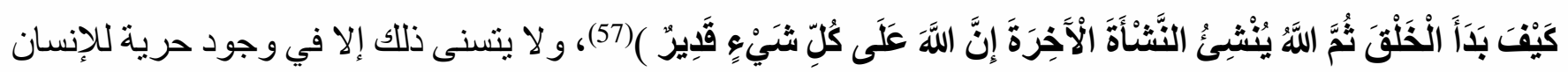

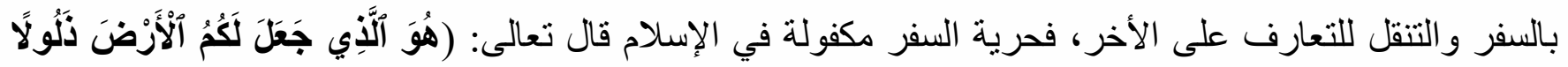

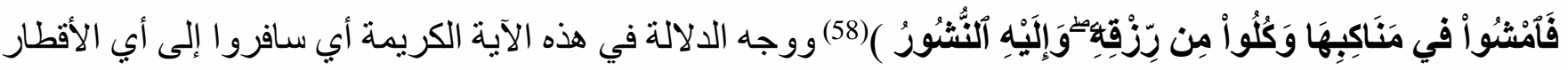

(55) د عبد المجيد أحمد المنشاوي، حماية حقوق الانسان في الظروف الاستثنائية، دراسة مقارنة بين أحكام القانون الدولي والثريعة

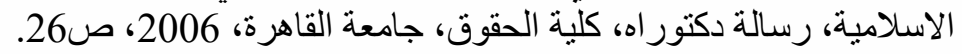




\section{محمد السعبد القز عة}

وترددوا في أقاليمها طلبا للرزق(59)، وشرع السفر لمن ضاقت به سبل العيش و الإقامة في مكان ما، فله أن ينتقل للعيش

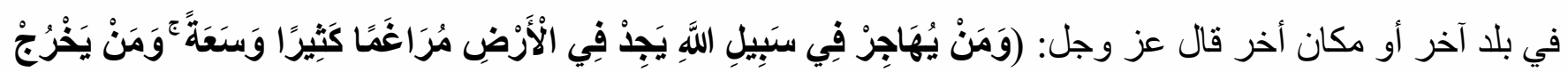

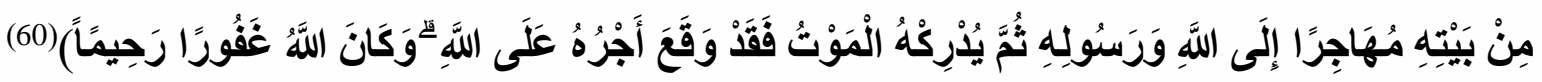
وفي السنة النبوية عن أبى فاطمة أنه قال يا رسول الله حدثني بعمل أستقيم عليه و أعمله قال رسول الله صله صله الله

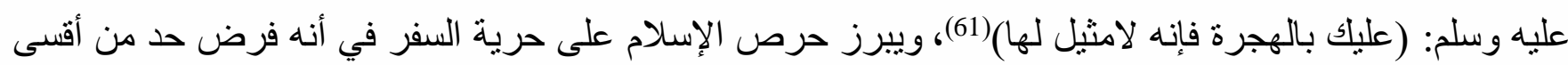

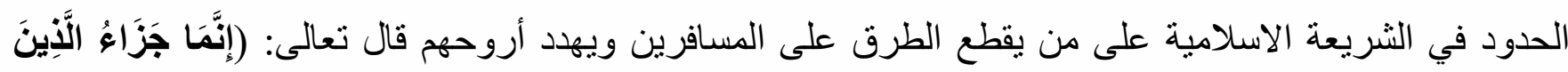

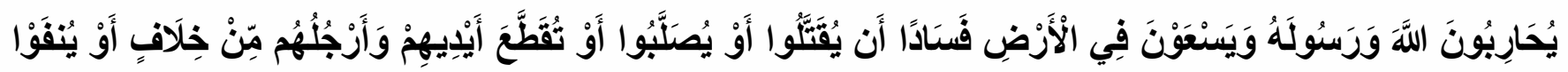

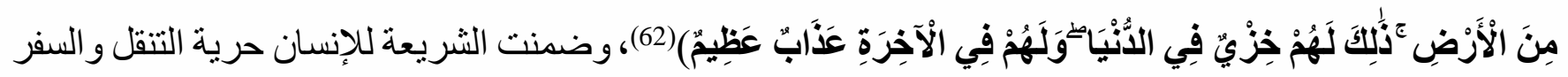

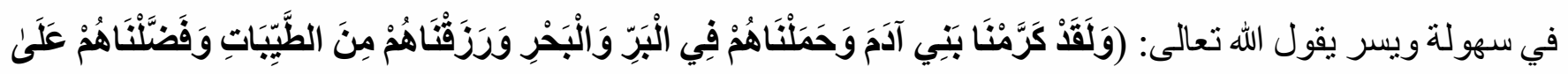

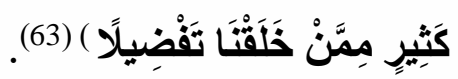

و إذا كانت تللك الآيات تجمع على مشروعية السفر والتنقل في الاسلام بل أنه في بعض الأوقات من الأمور

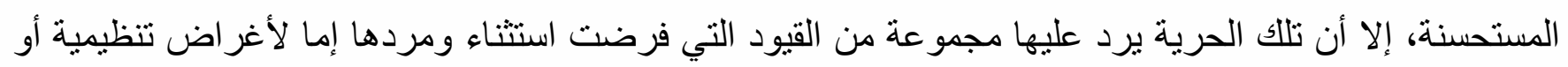
حماية الصحة العامة أو الأعر اض وفيما يلى بيانها: أولاً المنع السفر لأغراض تنظيمية: شرع المنع من السفر في الثريعة الإسلامية لعديد من الأمور منها أمور تتظيمية يقدر ها الحاكم ومنها ما قام به أمير المؤمنين عمر بن الخطاب رضى الله عنه حينما حظر على بعض كبار الصحابة الخروج من المدينة عاصمة الخلافة في ذلك الوقت نظر الحاجته إلى مشور اتهم وآرائهم، ويستفاد من ذلك أنه يجوز لولى الأمر تقيد حرية السفر لفترة زمنية إذا كانت هناك مصلحة عامة(64)، وتقييد حريتهم بالسفر داخل حدود الدولة الإسلامية كانت لمصلحة المسلمين وليست من قبيل العقاب، وقرر الخليفة الثالث عثمان بن عفان - رضي الله عنه ـ تقييد حرية أبي ذر الغفاري ـ رضي الغي

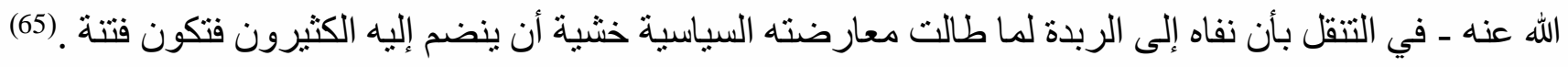

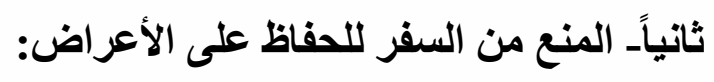

(59) تفسير القران العظيم، اسماعيل بن عمر بن كثير ، تحقيق سامي بن محمد سلامة، الطبعة الثانية، دار طيبة للنشر و التوزيع، 1420هـــ

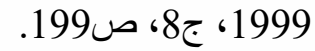

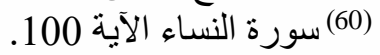

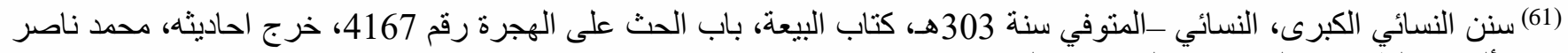

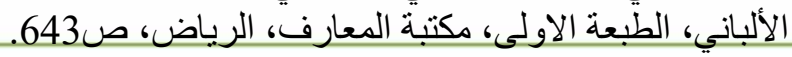




\section{محمد السعبد القز عهة}

تعد الحريات في الإسلام حريات منضبطة وخصوصاً فيما يتعلق بالكليات أو الضرورات الخمس في الإسلام ومن

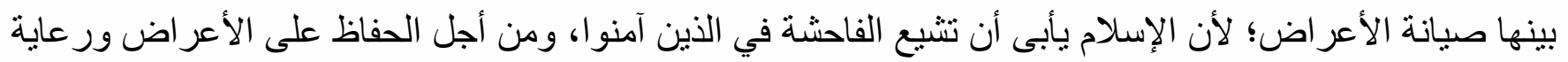

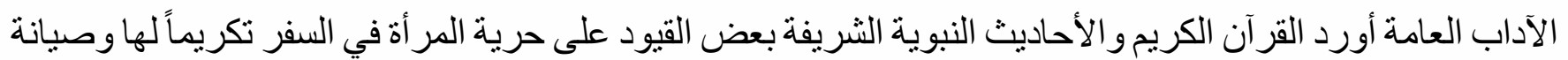

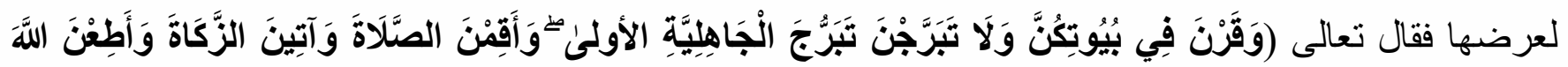

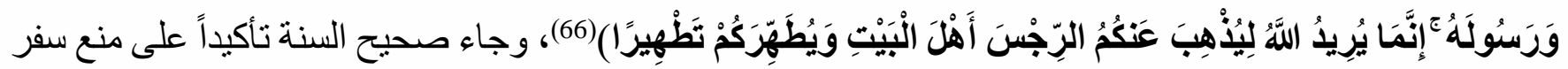

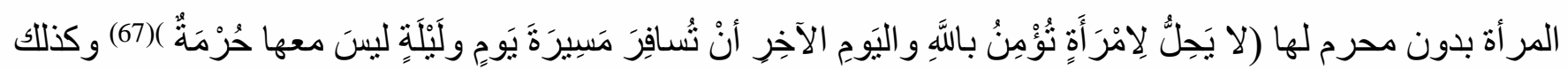

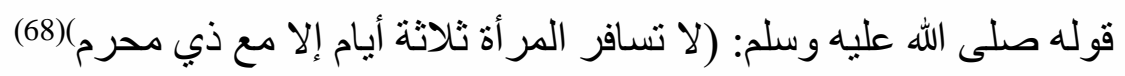
ثُالثاً المنع من السفر لغرض صحي:

أقرت الثريعة الإسلامية المنع من السفر في سبيل المحافظة على الصحة العامة للمسلمين فجاء حديث الرسول صلى الله عليه وسلم: (إذا سمعتم بالطاعون في أرض فلا تدخلو ها و إذا وقع بأرض وأنتم فيها فلا تخرجوا منها)(69)، وفي نهي الرسول صلى الله عليه وسلم من الخروج من الأرض التي وقع بها الطاعون ولا الدخول فيها؛ لما في ذلك من مخاطر كبيرة من التعرض للوباء، و بالتالي يمكن من خلال المنع تحقيق حصر الوباء في نطاق محدد و منعا لانتشاره و هو ما يعرف حاليا (بالحجر الصحي)(70)، ولعل هذا المنهج النبوي تجسد على أرض الواقع في الوقت الحالي مع انتشار فيروس (كورونا) المستحدث 19 covid وكيف أثناد عموم العالم بتلك التوجيهات النبوية، و على هدى قول الرسول محمد صلى الله عليه وسلم سار أصحابه من بعده، وذلك حينما انتشر طاعون عمواس(71)في العام الثامن عشر من الهجرة، وكان عمر بن الخطاب رضي الله عنه قد خرج من منطقة تسمى سرغ تقع على حدود الحجاز و الثنام فلقيه أمر اء الجند وأخبروه بانتثار المرض فقرر بعد المشاورة الرجوع(72)، وبذلك منع أمير المؤمنين عمر بن الخطاب السفر تغليباً لمصلحة العامة وحفاظاً على الصحة العامة لحصر الوباء في مكان محدد، وقام أمير المؤمنين عمر بن الخطاب بتقييد حرية امر أة في التتقل مريضه بالجزم بالر غم من أنها كانت تمارس شعيرة دينية وهى الطواف بالبيت الحر ام، فقال لها يا أمة الله لو جلست في بيتك لا تؤذين الناس؟ وفي ذلك حماية للطائفين بالبيت الحرام من العدوى، وقد

(66) سورة الاحز اب، جزء من الآية 33.

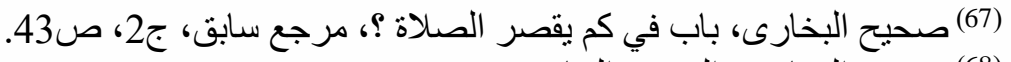

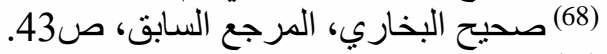

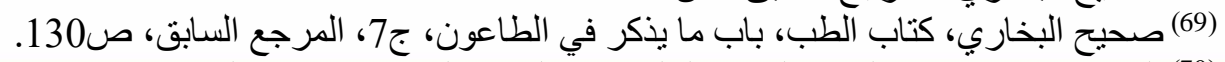

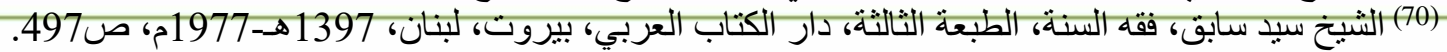
(71) و عمواس هي بلدة صغيرة تقع بيت القس و الرملة، وسمى الظّاعون بهذا الاسم نسبة اليها، لأنها كانت أول بلدة ظهر الداء فيها، ومنها

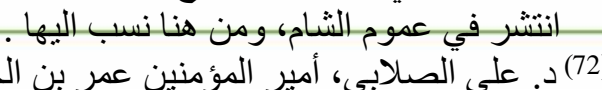

(72) د. على الصلابي، أمير المؤمنين عمر بن الخطاب شخصيته وعصره، 2002، بدون دار نشر ورقم طبعة، ص260. 
التزمت المر أة وجلست في بيتها ولم تخرج، وبعد وفاة عمر بن الخطاب فيل لها: أخرجي فإن الذي منعك الطواف قد

مات، رفضت الخروج وأجابت: و الله ما كنت لأطيعه حياً و أعصيه ميتاً(73). 


\section{محمد السعبد القز عة}

رابعاً: المنع من السفر في المواد الجنائية شرعاً: يكمن الأساس الشرعي للمنع من السفر في المواد الجنائية في الثريعة الاسلامية وفقاً لر أي فقهي في التعزير؛ باعتبار أن التعزير يجوز في غير معصية، إذا كانت المصلحة العامة تقتضيه، ومثال ذلك قيام رسول الله صل الله عليه وسلم بحبس رجل اتهم بسرقة بعير لمجرد الاتهام ولم تكن هناك معصية تستوجبه (74) في حين ذهب ر أي فقهي آخر أن ما حدث من رسول الله صلى الله عليه وسلم بالحبس يعد إجراء من إجر اءات التحقيق قصد به الاحتياط حتى تظهر الحقيقة، وهذا الاحتباط تدعو إليه المصلحة، ويقابل الحبس الاحتياطي في النظم القانونية الوضعية، وهو بذلك لا يعد

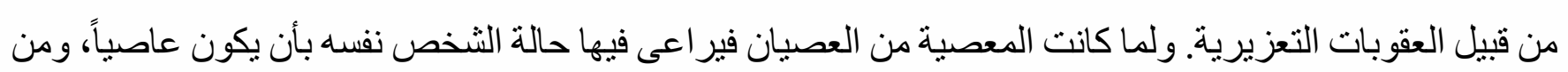
ثم إذا لم يكن الثخص مكلفاً كالصبى فلا يتأتى أن يكون عاصياً؛ إذ لا معصبة بغير تكليف، ومع ذلك يكون تعزيره

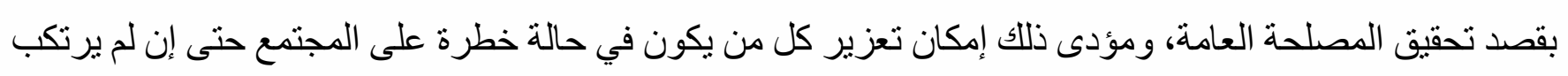
معصية(75). وفي تقديري أن المنع من السفر في المواد الجنائية في الثريعة الإسلامية يجد أساسه بأنه إجر اء من إجر اءات

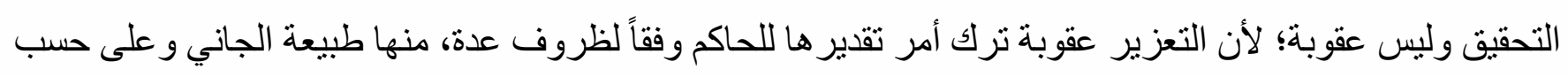
المكان و الزمان، فقد عزر رسول الله صلى الله عليه وسلم بالحرق و النفي، ويمكن في التعزير للحاكم أن يستحدث من العقوبات ما ير اه ملائماً، و لا تكون العقوبة إلا بحكم، والغرض من المنع من السفر هو مجرد التحفظ على المتهم خشية الهرب، وليس عقوبة. اجمالاً يمكن القول أن الثريعة الإسلامية قد رسمت الأطر القانونية لتحقيق الموازنة بين المصالح العامة و المصالح الخاصة عند ممارسة حرية السفر من خلال تقييده للحفاظ على الصالح العام أو الصحة العامة و الآداب

\section{المطلب الثاني}

\section{حرية السفر ومشروعية المنع منه في المواثيق الدولية والإقليمية}

تعتبر حرية السفر من الحريات الأساسية المهمة للإنسان، وقد تضمنت المعاهدات والمو اثيق الدولية فضلاً عن

التشريعات الوطنية العديد من النصوص التي تكفل صيانتها على الوجه الصحيح، وفيما يلي بيان ذلك من خلال:

(74) شرح الدردير على اقرب المسالك لمذهب الامام مالك، لأبى البركات الدردير العدوى المالكي الأزهري، طبع بو لاق 1281هـ، ج4، ص ص17 (75) (75) د عبد العزيز عامر، التعزير في الثريعة الاسلامية، دار الفكر العربي، الطبعة الخامسة، 1396هـ-1976م، ص88-89 . 


\section{محمد السعبد القز عة}

\section{الفرع الأول \\ حرية السفر ومشروعية المنع منه في المواثيق الدولية \\ أولا: الإعلان العالمي لحقوق الإنسان(76):}

قررت المادة (13) من الإعلان العالمي لحقوق الإنسان حرية الإنسان في التنقل والسفر واختيار محل إقامته حيث جاء فيها: (1- لكل فرد حرية التنقل واختيار محل إقامته داخل حدود الدولة، 2ـ لكل فرد حق مغادرة أي بلد، بما في ذلك بلده، وفي إلى بلده) (77)، ومفاد ذللك أنه لن تكتمل حقوق الإنسان وحريته إلا إذا شعر أنه حر غير مقيد في سفره وتنقله، وفي اختيار مكان إقامته داخل حدود دولته، وكذللك حقه في مغادرة أي بلد يشاء بما في ذلك بلده والعودة إليه،، وليس معنى النص على حرية السفر أنها مطلقة من كل القيود، و إنما يعنى تنظيمها وضمانها وفقا للقانون، ويبدو ذللك جليا فيما أورده ذات الإعلان في المادة (29) منه في الفقرة الثانية والتي جاء فيها: (لا يخضع أي فرد في ممارسة حقوقه وحرياته، إلا للقيود التي يقر ها القانون مستهدفا منها حصر ا ضمان الاعتر اف الو اجب بحقوق وحريات الآخرين و احتر امها ......) ويثار تساؤل حول القيمة القانونية للإعلان العالمي لحقوق الإنسان تأتي الإجابة على هذا التساؤل بأنه وفقا للرأي الغالب في الفقه القانوني بأن لهذا الإعلان فيمة أدبية و إرشادية للاول عند إعداد تشريعاتها الداخلية وعند إبرامها للمعاهدات الدولية(78)، وبالتالي لا يمكن إغفاله أو التغاضي عن به بهن نصو صهـ.

ثانيا: العهدالاولي للحقوق المدنية والسياسية(79) قرر العهد الدولي للحقوق المدنية والسياسية حماية حق الإنسان في السفر والتنقل وذلك عبر ما قررته المادة 12 و التي جاء فيها أن: 1- لكل فرد يوجد على نحو قانوني داخل إقليم دولة ما، حرية التنقل فيه وحرية اختيار مكان إقامته 2- 2 لكل فرد حرية مغادرة أي بلد بما في ذلك بلده .

(76) الصادر في 10 ديسمبر 1948 ديمبر

(77) د محمود شريف بسيوني، الوني، الوثائق الدولية المعنية بحقوق الإنسان، المجلد الأول الوثائق العالمية، الطبعة الأولى، دار الثروق، 1423هــ

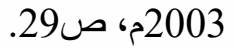

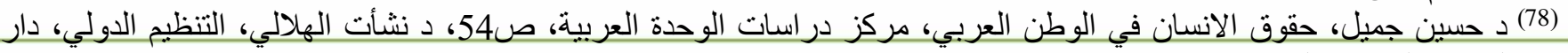

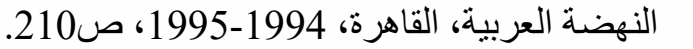

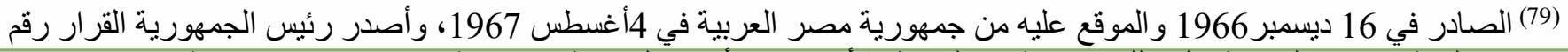
537لسنة في 1981 بالمو افقة على تللك الاتفاقية مع التحفظ بشأن مر اعاة أحكام الثريعة الاسلامية و عدم تعارض الاتفاقية معها. 


\section{محمد السعبد القز عة}

3- - ل ا يجوز تقييد الحقوق المذكورة أعلاه بأي قيود غير تلك التي ينص عليها القانون، وتكون ضرورية لحماية

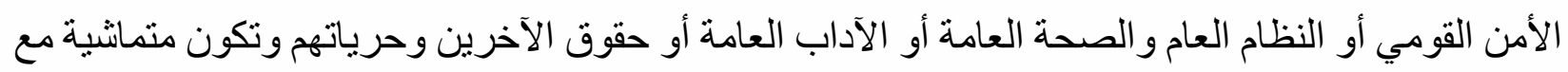
الحقوق الأخرى المعترف بها في هذا العهد. 4- - ل الا يجوز حرمان أحد تعسفا من حق الدخول إلى بلدها. ولما كانت هناك أهمية كبيرة لتفسير مو اد العهد، اضطلعت اللجنة المعنية بحقوق الإنسان(80)، بهذه المهمة من خلال إصدار التعليقات العامة على مو اد العهد والتي تعد بمثابة مذكرة تفسيرية لمو اد العهد الدولي، وقد تناول التعليق العام رقم (27) تفسير المادة 12من هذا العهد بشأن حرية التنقل وما يندرج في إطار موضوع المنع من مغادرة الدولة،

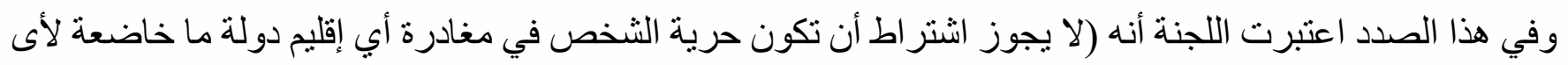
غرض محدد أو متوقفة على الددة التي يختار الثخص أن يبقى خلالها خارج البلد، وبالتالي فإن السفر خارج البلد مكفول بالإضافة إلى المغادرة بغرض الهجرة بصورة دائمة )، وفيما يتعلق بالوثائق اللازمة للسفر ذهبت اللجنة في تعليقها إلى أنه نظر الأن السفر الدولي يتطلب عادة وثائق ملائمة ويتطلب جواز السفر بالتحديد، فإن الحق في مغادرة بلد ما يجب أن يشمل الحق في الحصول على وثائق السفر اللازمة، وأن إصدار جواز ات السفر ـوتمديد فترة صلاحيتها ـ هو من واجب دولة جنسية الفرد(81) .

و الملاحظ أن المادة 12 من في الفقرة الثالثة تتص على ظروف استثنائية يمكن فيها تقييد الحقوق المقررة بموجب الفقرتين 1، 2 فأجازت الثالثة من ذات المادة تقييد هذه الحقوق؛ لحماية النظام العام و الآداب العامة أو حقوق وحريات الآخرين، وكذلك حماية الأمن القومي ولكن شريطة أن ينص على هذه القيود في القانون وأن تكون متسقة مع جميع

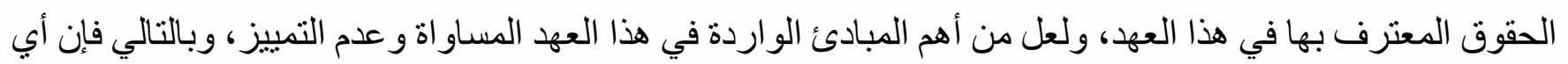
تقييد لحرية السفر والتنقل لا ينبغي أن ينطوي على تمييز أيا كان نو عه سواء على أساس العرق أو اللون أو الجنس أو

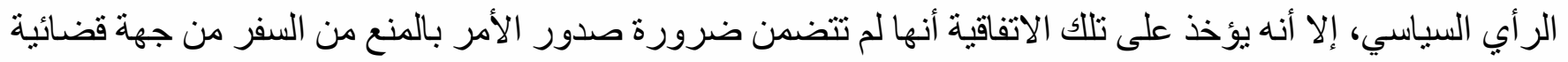
بما يعزز من حق الإنسان وحرياته الأساسية في مواجهة عصف السلة السلطات . ثالثاً: اتفاقية جنيف الرابعة لحماية المدنيين(82):

أقرت اتفاقية جنيف الرابعة لحماية المدنيين وقت الحرب حق التنقل والسفر بدون عوائق تضعها سلطات الاحتلال، فقد جاء في المادة (35) من تلك الاتفاقية بأن (أي شخص محمي ير غب في مغادرة البلد في بداية النزاع أو

(80) اللجنة المعنية بحقوق الانسان نم إنشائها بموجب المادة 28 من العهد الدولي للحقوق المدنية والسياسية وهي هيئة خبر اء مستقلة التي

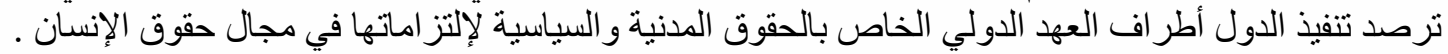

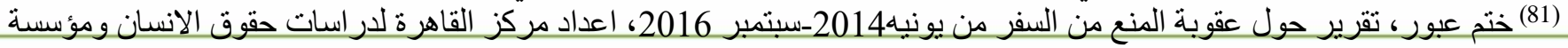

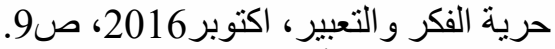
(82) الصنادرة في 12 أغسطس الغكربر 1949. 
المنع من السفر في المواد الجنائية

\section{محمد السعبد القز عة}

خلاله يحق له ذللك، إلا إذا كان رحيله يضر بالمصالح الوطنية للدولة، ويبت في طلبة لمغادرة البلا طبقاً لإجراءات قانونية .......) واثترطت المادة (36) أن تتم عملية السفر تلك في ظروف مناسبة، حيث جاء فيها: (تنفذ عمليات المغادرة التي يصرح بها بمقتضى المادة السابقة في ظروف ملائمة من حيث الأمن، والثروط الصحية، و السلامة و التغذية....) وبالر غم مما يظهر من خلال نص المادتين من حرص واضعو الاتفاقية على كفالة حرية التنقل والسفر مارك

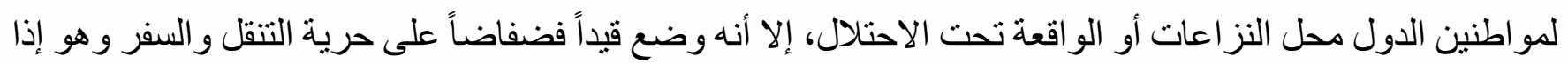
كان الرحيل يضر بالمصالح الوطنية، وهذا الثرط من الاتساع بما بسمح بالعصف بحرية السفر والتنقل تحت ستار الإضر ار بالمصالح الوطنية.

رابعاً: الاتفاقية الدولية لحماية حقوق العمال المهاجرين وأفراد أسرهم(83):

قررت المادة الثامنة من الاتفاقية الدولية لحماية حقوق العمال المهاجرين وأسر هم في فقرتها الأولى حق العمال المهاجرين و أفر اد أسر هم في مغادرة أي دولة بما في ذلك دولة منشئهم، و عدم خضو ع هذا الحق لأي استثناءات أو قيود سوى التي تقتضى حماية الأمن الوطني أو النظام العام، أو الصحة العامة، أو الآداب العامة أو حقوق وحريات الغير،

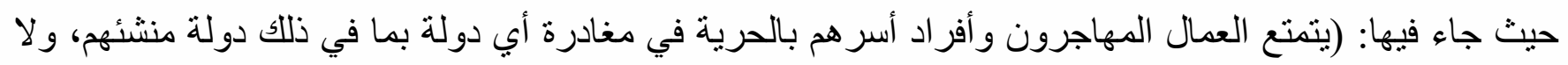
يخضع هذا الحق لأى قيود باستثناء القيود التي ينص عليها القانون وتقتضى حماية الأمن الوطني، أو النظام العام، أو الصحة العامة، أو الآداب العامة أو حقوق الغير وحرياتهه، وتكون متمشية مع الحقوق الأخرى المعترف بها في هذا

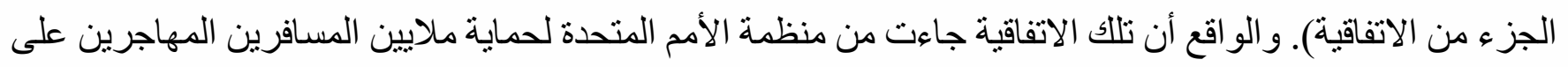
مستوى العالم(84).

\section{الفرع الثاني}

\section{حرية السفر ومشروعية المنع منه في المواثيق الإقليمية(85)}

حظيت حرية السفر بالكثير من الاهتمام عبر الاتفاقيات الدولية والمواثيق الإقليمية ومن هذه الاتفاقيات: الاتفاقية

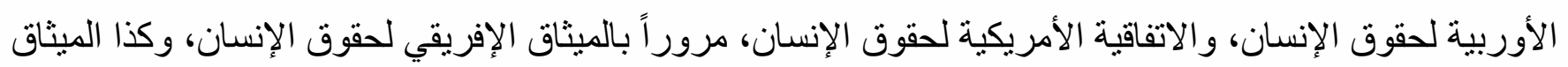
العربي لحقوق الإنسان، كل تللك الاتفاقيات جاءت لتكريس حرية السفر و التنقل مع بيان القيود الواردة عليه .

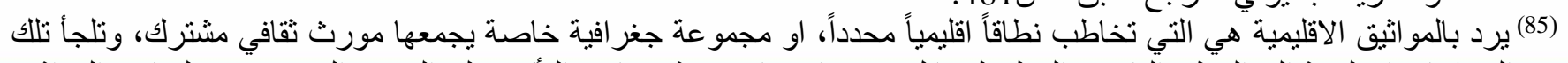

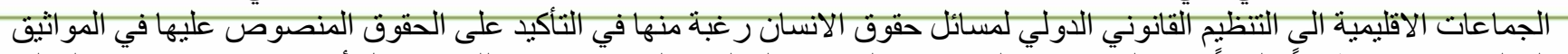

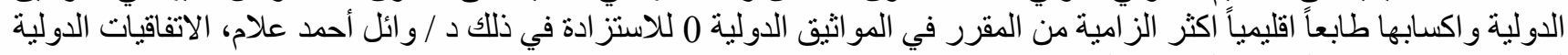


المنع من السفر في المواد الجنائية

\section{محمد السعبد القز عة}

أولاً_- الاتفاقية الأوروبية لحقوق الانسان(86):

وقعت هذه الاتفاقية في الر ابع من نوفمبر 1950، ووضعت موضع التنفيذ في الثالث من سبتمبر 1953، والاسبه واضضيف إليها عدة برونوكو لات بعد توقيعها تضمنت بعض الإضافات وكذا تعديلات لبعض مو اد الاتفاقية، وجاء في البروتوكول الر ابع(87) الملحق بتلك الاتفاقية في المادة الثانية بأنه (1 لكل شخص موجود على وجه مشروع في إقليم دولة الحق في حرية التنقل فيها وحرية اختيار محل إقامته في نطاق هذا الإقليم. 2- لكل شخص حرية الخروج من أية دولة بما في ذلك دولته. 3- لا يجوز وضع قيود على حرية ممارسة هذه الحقوق غبر تللك المنصوص عليها في القانون وتقتضيها الضرورة في مجتمع ديمقراطي لمصلحة الأمن القومي أو الأمن العام، للمحافظة على النظام العام أو منع الجريمة أو حماية الصحة و الأخلاق أو حماية حقوق وحريات الآخرين. 4- يجوز أن تخضع أيضاً الحقوق الو اردة في الفقرةالأولى، في مناطق معينة، لقيود طبقاً للقانون وتبرر ها المصلحة. العامة في مجتمع ديمقر اطي)(م8). وضمنت حرية السفر والتنقل وفقا للاتفاقية الأوروبية لحقوق الإنسان وآليات تنفيذها اللجنة الأوروبية لحقوق الإنسان، لجنة وزراء مجلس أوربا، المحكمة الأوروبية لحقوق الإنسان، وهي جميعها لها دورها الرقابي، ولا يعلو أحدها على غيره من الأجهزة(89).

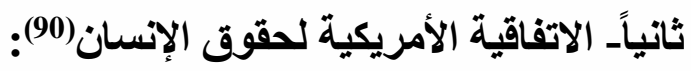
جاء في المادة(22) من الإتفاقية الأمريكية لحقوق الإنسان بأن( 1- لكل شخص متو اجد بصورة شرعية في أر اضي دولة طرف حق التنقل و الإقامة مع مر اعاة أحكام القانون. 2- لكل شخص حق مغادرة البلد المتو اجد فيه بحرية بما في ذلك مغادرة وطنه . 3- لا يجوز تقييد ممارسة الحقوق المذكورة أعلاه إلا بموجب قانون وبالقدر الذى لابد منه في مجتمع ديمقر اطي

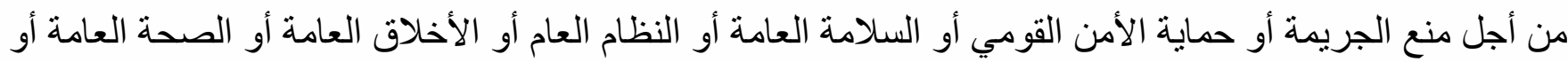
حقوق الآخرين أو حرياتهم .

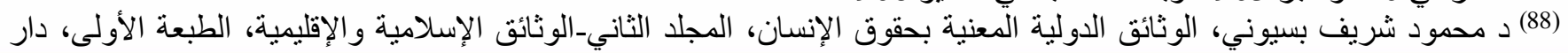




\section{محمد السعبد القز عة}

4- يمكن أيضا تقييد ممارسة الحقوق المذكورة في الفقرة (1) بموجب القانون في مناطق محددة ولأسباب تتعلق

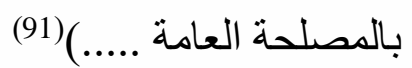
و تضمنت تلك الإتفاقية في الباب الثاني منها وسائل الحماية لضمان صيانة حقوق الانسان وحرياته الأساسية لذلك تم إنثاء اللجنة الأمريكية لحقوق الإنسان، والمحكمة الأمريكية لحقوق الإنسان. ثالثاً. الميثاق الإفريقي لحقوق الإنسان والثعوب(92): جاء في المادة 12من هذا الميثاق بأن (1- لكل شخص الحق في التنقل بحرية واختبار إقامته داخل دولة ما شريطة الالتز ام بأحكام القانون

2- لكل شخص الحق في مغادرة أي بلد بما في ذلك بلده، كما أن له الحق في العودة إلى بلده، و لا يخضع هذا الحق لأية قيد إلا إذا نص عليها القانون وكانت ضرورية لحماية الأمن القومي، و النظام العام، الصحة، أو الاخلاق العامة (93) ووفقا لتلك المادة يتضح حرص الميثاق الإفريقي على التأكيد على حرية السفر ، غير أنه يؤخذ على هذا الميثاق أنه لم يأت بضمانات تكفل صيانة حرية الإنسان في السفر ، وذلك على غرار الاتفاقية الأوربية والأمريكية لحقوق الإنسان .

رابعاً الميثاق العربي لحقوق الانسان(94)

باستقر اء نصوص الميثاق العربي لحقوق الإنسان يتضح أن حرية السفر جاء النص عليها في المادة (21) حيث

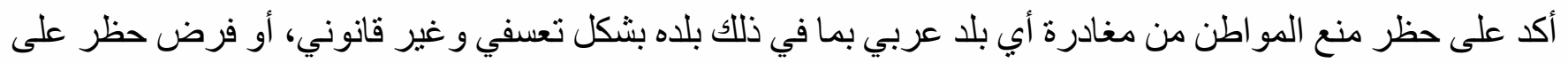
إقامته في جهة معينة، أو إلز امه بالإقامة في أب جهة من ملئ بلدها. وجاءت المادة (22) لتؤكد على حرية السفر (لكل فرد مقيم على إقليم دولة، حرية الانتقال واختيار محل الإقامة في أي جهة من هذا الإقليم في حدود القانون )، وأرسى الميثاق العربي على نسق الميثاق الإفريقي فيما يتعلق بالتأكيد على حرية السفر (95)، غير أن تللك الاتفاقية يوجه إليها ذات النقد الموجه للميثاق الإفريقي لحقوق الإنسان هو افتقادها لأي آلية تضمن وضع تللك النصوص موضع التنفيذ.

\section{المطلب الثالث}

\section{حرية السفر والمنع منه في التثريعات الوطنية}

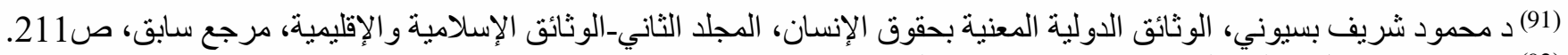

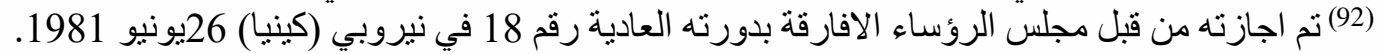

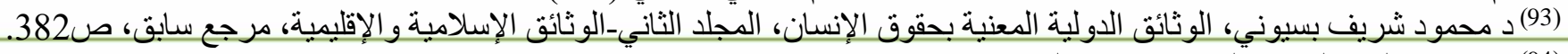

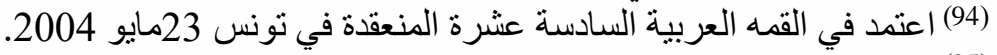

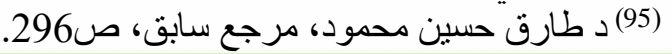


المنع من السفر في المواد الجنائية

\section{محمد السعبد القز عة}

لم تتخلف التشريعات الوطنية عن المو اثيق الدولية والإقليمية في حماية حرية السفر ، وإقرار العديد من الضمانات التي تكفل ممارسة هذه الحرية، غير أن التشريعات الوطنية تميزت عن المو اثثيق الدولية والإقليمية بأن قو اعدها المنظمة

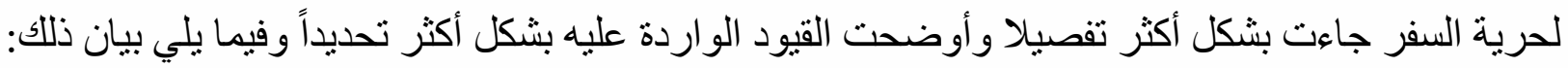

\section{الفرع الأول}

\section{حرية السفر والقيود الواردة في الاساتير}

تسمو القواعد الدستورية على كافة القواعد القانونية، وينتج عن ذلك عدم جواز إصدار قانون على خلاف

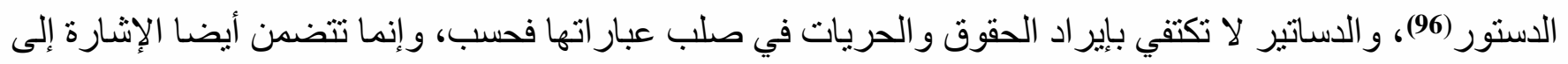
أساليب وكيفية حمايتها عن طريق القو انين و اللوائح، الأمر الذى يكفل ممارسة تلك الحريات و عدم إهدار ها أو الانتقاص منها(97)، وبين الدستور و القانون الجنائي اتساق تشريعي وفقهي فلا يجوز أن يكون بينهما تناقض، و لا يجوز أن يتضمن

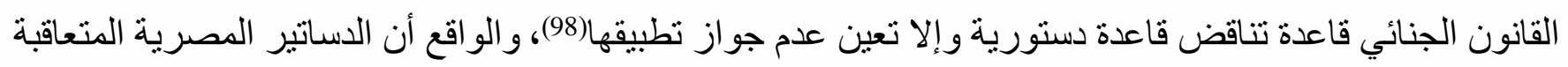
قد درجت على تقرير مبدأ حماية الحريات المتعددة للفرد على نحو يكفل لها الوجود والاكتمال ضد عسف الألف الأفراد و عسف الدولة سواء(99)، إلا أن هذا لا يمنع الدولة من تنظيمها على النحو الذى يكفل الموازنة بين حقوق الأفراد

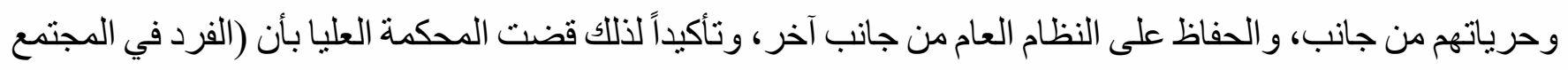

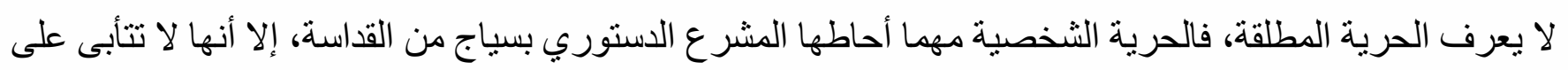
القيود و الحدود إذا اقتضت مصلحة المجتمع فرض هذه القيود و الحدود )(100). وتتغل حرية السفر والتتقل قيمة دستورية سامية ويظهر ذلك جلياً بالنص عليها في الاساتير المصرية المتتابعة؛ ودئ فجاءت المادة (41) من دستور 1971 (101)، وقررت بأن (الحرية الثخصية حق طبيعي و هي مصونة لا تمس، وفيما

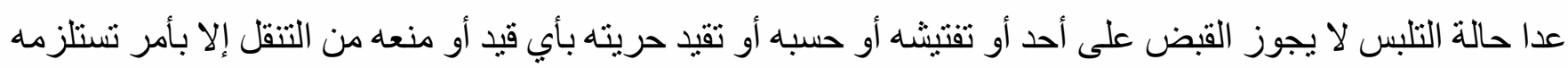
ضرورة التحقيق وصيانة أمن المجتمع، ويصدر هذا الأمر من القاضي المختص أو النيابة العامة وفقا لأحكام القانون ويحدد القانون مدة الحبس الاحتباطي ) كما حظرت المادة (50) من ذات الدستور إلز ام الفرد الإقامة في جهة معينة أي تحديد إقامته في مكان بعينه، وحظرت المادة (51) إبعاد أي مو اطن عن البلاد أو منعه من العودة إليها وجاء في المادة

(96) د عبدالواحد محمد الفار، قانون حقوق الانسان في الفكر الوضعي و الثريعة الاسلامية، دار النهضة العربية، القاهرة، 1996، ص401.

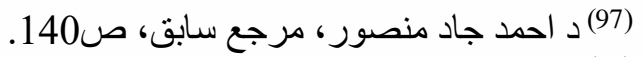

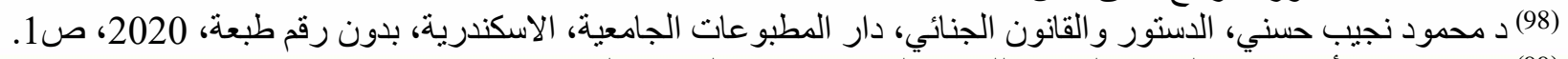

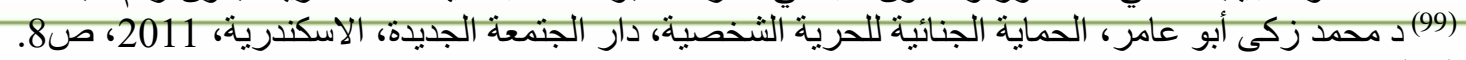

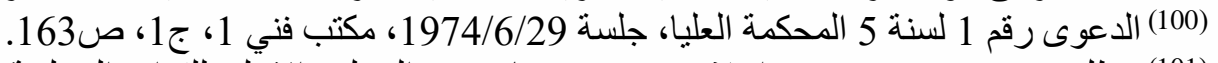
(101) عطل دستور 1971 بموجب اعلان دستوري صادر عن المجلس الاعلى للقوات المسلحة في 13 فبراير 2011. 
(52) منه بأن (للمواطنين حق الهجرة الدائمة أو المؤقتة إلى الخارج، وينظم القانون هذا الحق وإجراءات وشروط الهجرة ومغادرة البلاد).

أما دستور 2012 الذي حل محل دستور 1971 الملغى فقد قرر في المادة (42) بأن (حرية التنقل والإقامة و الهجرة مكفولة، ولا يجوز بأي حال من الأحوال إبعاد أي مو اطن عن إقليم الدولة، ولا منعه من العودة إليه، و لا يكون

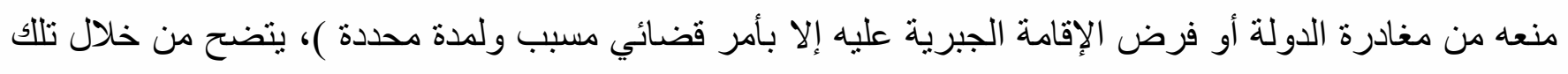

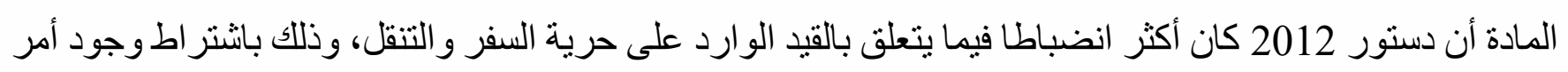

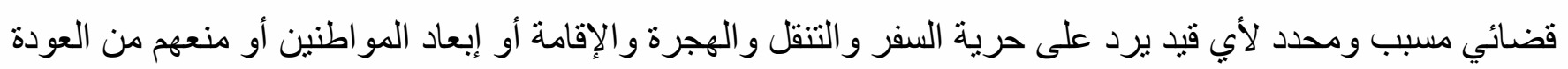
إلى وطنهم. أما فيما يتعلق بالدستور الحالي الصادر 2014 فجاء كافلا لحرية السفر وفقا للمادة (62) التي جاء فيها أن (حرية التنقل و الإقامة و الهجرة مكفولة، ولا يجوز إبعاد أي مو اطن عن إقليم الدولة، ولا منعه من عودته إليه، و لا يكون منعه من مغادرة إقليم الدولة، أو فرض الإقامة الجبرية عليه، أو حظر الإقامة في جهة معينة عليه، إلا بأمر قضائي مسبب الإبه

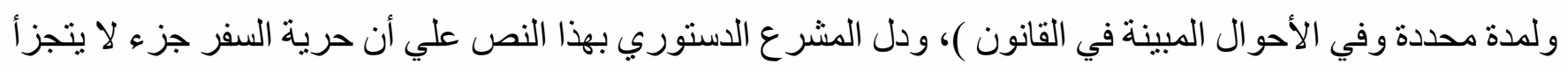
من الحريات العامة، وأن على الثارع العادي أن يكفل حق المو اطنين في ممارستها بحيث يمتنع عليه تقييدها دون

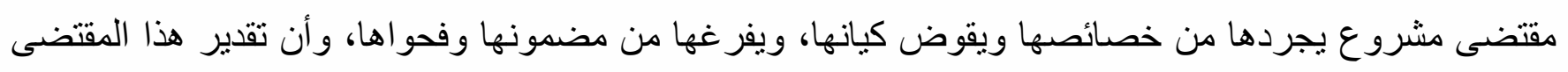

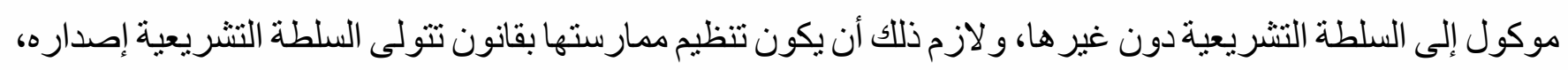
وتتوخي في المنع استصحاب الأصل ـ الحرية في السفر -، وتتجنب المنع باعتباره استثناء لا يجوز التوسع فيه. لذلك قضت المحكمة الدستورية العليا بعدم دستورية نص المادتين 8، 11 من القانون 97 لسنة 1959 بشأن جواز ات السفر فيما تضمنتاه من تفويض وزير الداخلية في تحديد شروط منح جواز السفر ، وتخويله سلطة رفض منس هنح

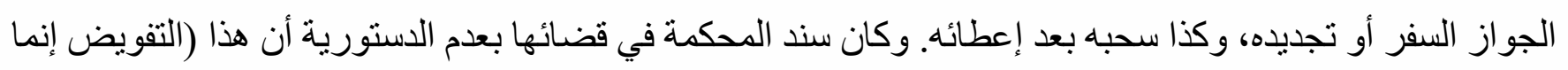
يتمخض عن تنصل المشرع من وضع الأسس العامة التي تنظم موضوع جوازات السفر بأكمله على الرغم من كونها الوسيلة الوحيدة لتمكين المو اطن من مغادرة بلده والرجوع إليه، وارتباط ذلك وثيقاً بالحقوق التي يكفلها الدستور (102).

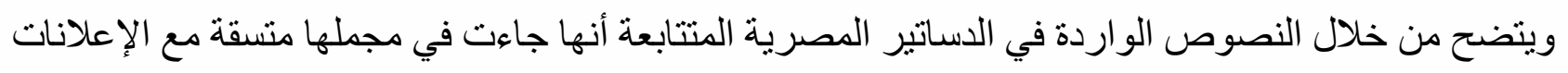

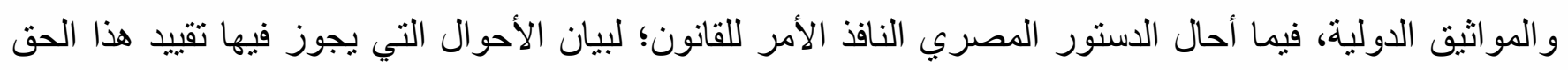
المكفول دستوريا، ولكنه اشترط أن يكون ذلك بأمر قضائي ولمدة محددة، ويترتب على اعتبار حرية السفر حقاً دستورياً

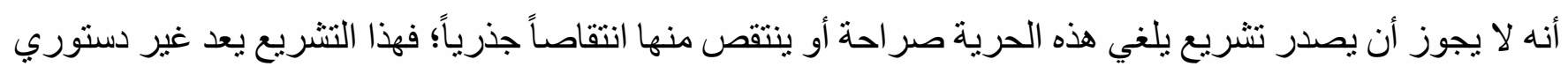




\section{محمد السعيد القز عة}

ويمكن الدفع بعدم دستوريته واللجوء إلى المحكمة الدستورية بطلب إلغائه، ولا يجوز للسلطة التنفيذية ممثلة في وزارة الأخلية أن تمنع سفر المواطنين للخارج منعا مطلقاً، أو تضع شروطا للسماح بالسفر نرقى إلى مستوى العر اقيل غير المبررة وقعاً وقانوناً(103).

وجاءت أحكام القضاء الإداري لتنسج على ذات المنوال (فقررت أن الحرية الثخصية بجميع صنوف أوجها ممارستها، وسائر دروب أوجهها بما في ذلك حرية التنقل داخل البلاد أو خارجها، مصونة ومكفولة دستورياً بما تكون التدان معهه عصية على النيل منها بحرمان، أو تقييد لأوجه ممارستها بافتنئات، حيث حظر المشرع ما يؤدي بها إلى أي مما ذكر، مضيقاً من ولوج أي طريق أو اتخاذ أي إجر اء من شأنه تقييد الحرية بما في ذلك منع الثخص من بن التنقل إلا إذا

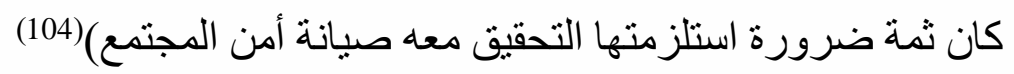
ذلك أن حرية السفر من الحريات اللصبقة بالإنسان و المستمدة من فطرته وطبيعته الإنسانية، ومن قو اعد القانون الطبيعي، وأن تدخل المشرع العادي لتنظيم استخدامها كي لا يعم البلاد الفوضى، وحتى يكفل للأفراد حسن

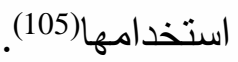

ونافذا لذلك جاء الكتاب الدوري رقم 6 لسنة 2017 الصادر من النائب العام بشأن ضمانات الحرية الثخصية التي كفلها الدستور و القانون و الذي قرر بأن (حرص الدستور في سبيل حماية الحريات العامة على كفالة الحرية الثخصية

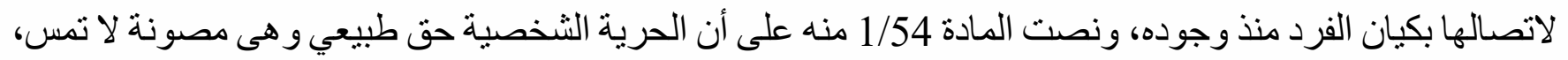

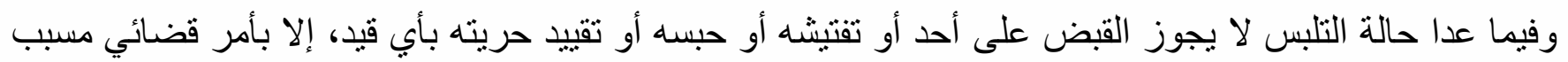
يستلزمه التحقيق ) (106).

ولكن يثار تساؤل هنا بـأن المشرع الاستوري قرر حماية حق الفرد في السفر والتنقل وأنه لا يجوز تقييا هذا

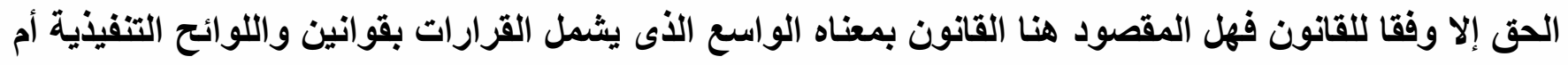
يقصد به القانون بمعناه الضيق أي الصادر عن السلطة التشريعية؟ الو اضح أن الأصل هو حرية الإنسان في السفر ، والتنقل وأن الاستثناء هو تقييد تلك الحرية، وبالتالي فإنه لا ينبغي

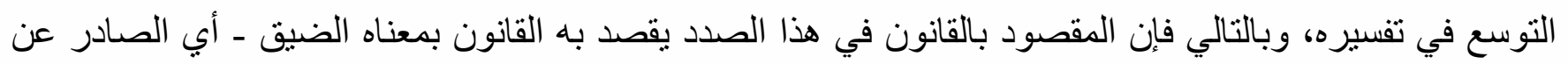

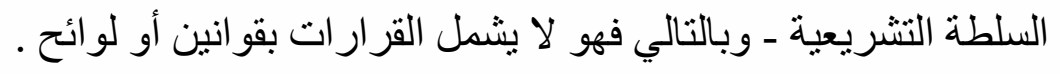

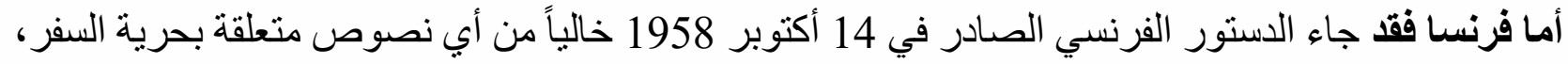
إلا أن لهذه الحرية مكانتها الأساسية في المجتمع الفرنسي، حيث وردت الحريات العامة في المادة 34، و الحريات الفردية 


\section{محمد السعبد القز عة}

في المادة 26، وقد أحالت المادة 34 من الدستور إلى البرلمان لإصدار القوانين اللازمة للنص على الضمانات الأساسية

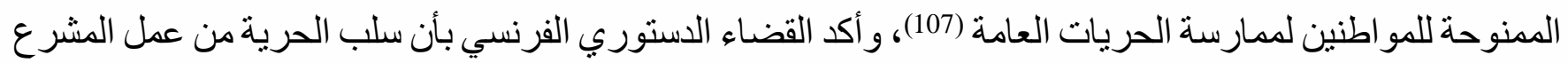

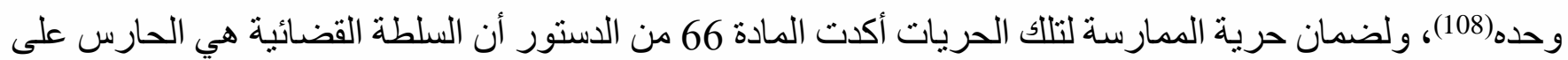
الحريات الفردية(109).

وقد أكد المجلس الدستوري في فرنسا على أن حرية التنقل مبدأ دستوري، ووصفتها محكمة النقض ومحكمة

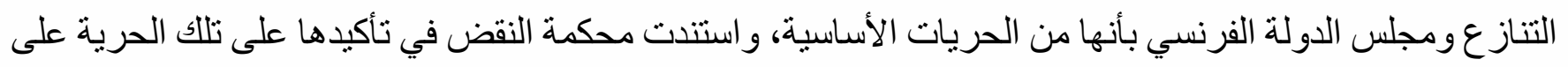
قو اعد القانون الدولي، بينما استندت كل من محكمة التناز ع ومجلس الدولة إلى القانون الداخلي(110)، لذلك جاء التهاء القانون

رقم 69/3 الصادر في 3يناير 1969 و المعدل بالقانون رقم 85/772 لفرض بعض القئه القيود على حرية السفر. و أكد قضاء مجلس الدولة الفرنسي على حرية السفر حيث قضى بأن (رفض الإدارة منح جواز السفر بسبب سبق إنق

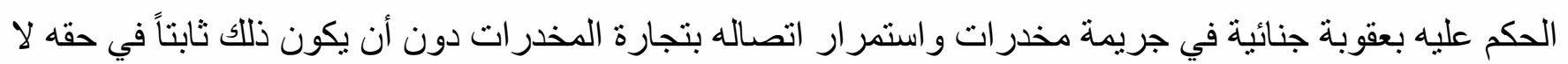

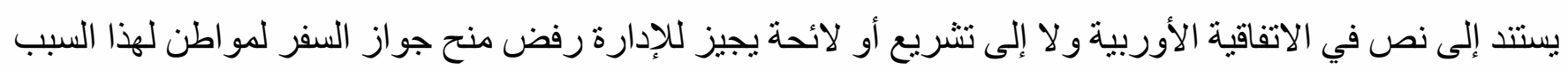

\section{الفرع الثاني}

\section{حرية السفر في التشريعات الداخلية والقيود الواردة عليه}

فضلاً عما قررته الدساتير من حماية لحرية السفر والتنقل، جاءت العديد من التشريعات الداخلية موضحة لمعالم تللك الحرية، وبينت القيود الواردة على تلك الحرية وفيما يلي بيان ذلك: أولاً: المنع من السفر في التثريع المصري: ولبن يرجع الأصل التاريخي للمنع من السفر في مصر إلى قرار وزير الداخلية 812 لسنة 1969 و الذى أوضح أنه يتم الإدر اج على قو ائم الممنو عين من السفر للأشخاص الطبيعيين في الحالات الآتية: الأسباب السياسية: يتم الإدراج بناء على طلب الأمن و النشاط الجنائي، و يتم إدراج المتهمين في قضايا الجنح

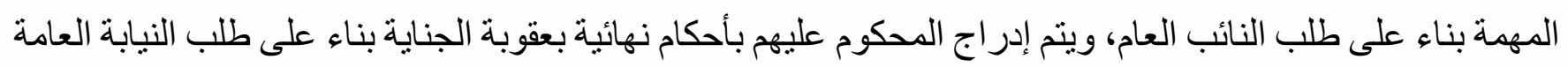
المختصة، ويتم إدر اج الخطرين على الأمن العام بناء على طلب مصلحة الأمن العام .

${ }^{(108)}$ conseil constit 28 nov 1973D .1974 .p .269.

(107) د نبيل مدحت سالم، مرجع سابق، ص1349.

${ }^{(109)}$ Jacques Godechot . Les constitution de la France depuis 1789, Edité par Gf Flammarion, Paris, 1995, p434-443.

(110) د نعيم عطية، د حسن محمد هند، النظام القانونى للمنع من السفر، دار الكتب القانونية، 2009، بدون رقم طبعة، ص14. (111)Trib.adm. Strasbourg 3 nov .1983,D.S. 1983,300,note J-F.Flauss. 


\section{محمد السعبد القز عه}

النشاط الوظيفي: ويكون بناء على طلب الأمن القومي في حالة وجود نشاط ضار عند انتهاء خدمة العاملين

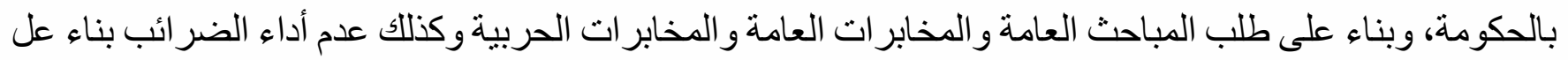

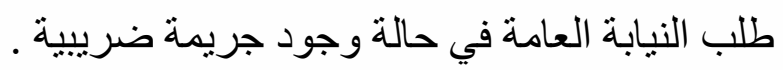
وبعد ذلك أصدر وزير الداخلية القرار 975 لسنة 1983 موسعاً للجهات التي يحق لها طلب الإدراج على قو ائم

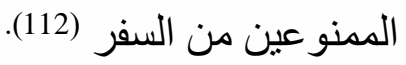
تلا ذلك قرار وزير الداخلية المصري رقم2214 لسنة 1994 وتعديلاته، و التي كان آخر ها التعديل الذي أجري بقر ار وزير الداخلية رقم 54 لسنة 2013 بشأن تنظيم قو اعد الممنوعين من السفر، ومر المنع من السفر بمرحلتين غاية في الأهمية، وذلك استناداً إلى المادتين(8، 11) من القرار بقانون رقم 97 لسنة 1959 بشأن جواز ونات السفر (113)، و واللذان

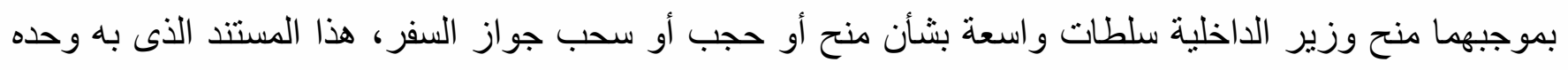
يستطيع الفرد أن يمارس حقه في السفر، حتى صدر حكم المحكمة الدستورية العليا بعدم دستورية نص المادتين(8، 11) من قانون 97 لسنة 1959وفيما يلى بيان ذلك من خلال: 1- المنع من السفر قبل القضاء بعدم دستورية المادتين (8،8، 11) من القرار بقانون 97 لسنة 1959بثأن جوازات

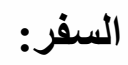
قررت المادة الأولى من قرار رئيس الجمهورية بالقانون 97 لسنة 1959في شأن جوازات السفر بأن (لا يجوز

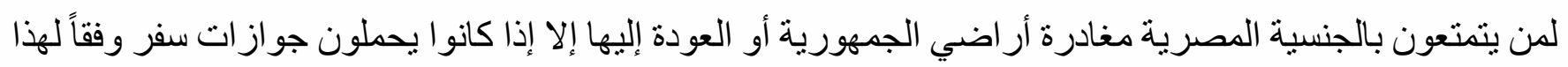

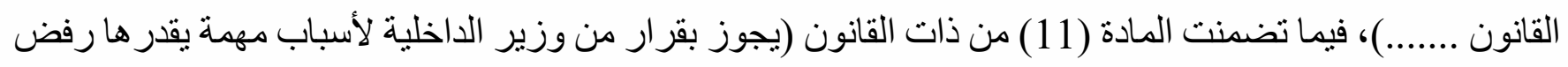
منح جواز السفر أو تجديده كما يجوز لله سحب الجواز بعد إعطائه)، ونم تنظيم قو ائم الممنو عين من السفر في القانون رقم (89) لسنة 1960 بشأن دخول و إقامة الأجانب بأر اضي جمهورية مصر العربية والخروج منها والذي جاء في لهاء المادة 34 منه بأن (ينعين بقرار من وزير الداخلية قواعد و إجر اءات تحديد الممنو عين من مغادرة البلاد، أو من الدخول إليها أو الانتقال بين إقليمها، وكيفية رفعها منها، ويتعين بقرار من وزير الداخلية اللجان التي تشكل في هذا الثنأن

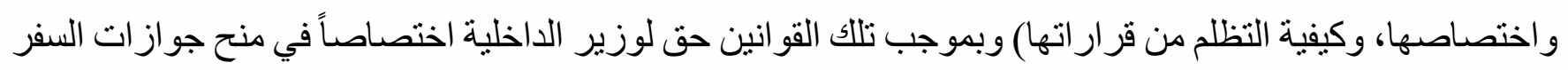

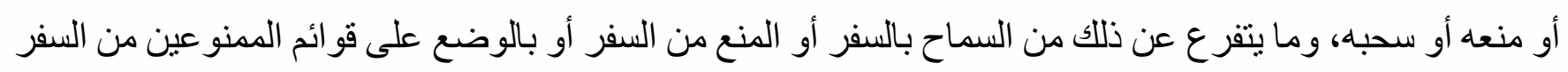


وبناء على ذلك أصدر وزير الداخلية القرار رقم 2214 لسنة 1994(114) بشأن تنظيم قو ائم المدنو عين من السفر و الجهات التي لها سلطة إدراج هذه الأسماء(115)، وبين قرار وزير الداخلية رقم 54لسنة 2013(116)، المعدل لقرار وزير الداخلية رقم 2214لسنة 1994 بشأن تنظيم قو ائم الممنوعين الجهات التي يحق لها الإدر اج على قو ائم الممنوعين من السفر وهي كالتالي (يكون الإدر اج على قو ائم الممنوعين من السفر بالنسبة للأشخاص الطبيعيين وبناء على طلب

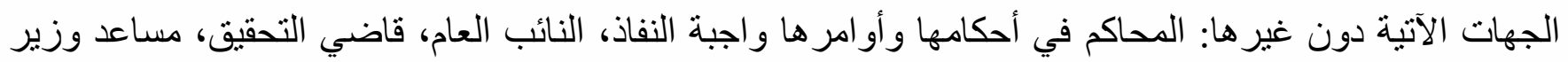
العدل للكسب غير المشروع، رئيس المخابرات العامة، رئيس هيئة الرقابة الإدارية، مدير إدارة المخابرات الحربية ومدير إدارة الثئون الثخصية والخدمة الاجتماعية للقوات المسلحة، والمدعى العام العسكري، مساعد وزير الداخلية لقطاع الامن الوطني، مساعد وزير الداخلية لقطاع مصلحة الأمن العام .

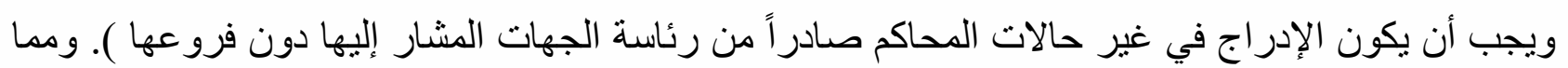
لاشك فيه أن قرار وزير الداخلية المعنى بتنظيم المنع من السفر قبل القضاء بعدم دستورية المادتين(8) 118) من القرار بقانون 97 لسنة 1959، يعد انتهاكاً صارخا لدستور 1971 و الذي بدوره أحال بموجب المواد(41،51،52) للمشرع وحده دون غيره تنظيم أمر المنع من السفر باعتباره قيداً على الحرية الثخصية، وكان مفاد هذه النصوص سالفة الذكر أن الإحالة حصرية بمعنى أن يحتكر المشرع هذا التنظيم والذي لا يخرج عن كونه تنظيم لهذه الحرية، وليس وضع القيود و العصف بالحقوق، ومفاده كذللك أنه تفويض انتهائي لا تفويض بعده، فليس للمشر ع بعد ذلك أن يفوض السلطة التنفيذية في هذا التنظيم بعد أن أصبح حكر اً عليه(117) لذلك جاء حكم محكمة النقض مؤكداً على هذا المبدأ بقوله (من المقرر بنص الفقرة الأولى من المادة 41 من

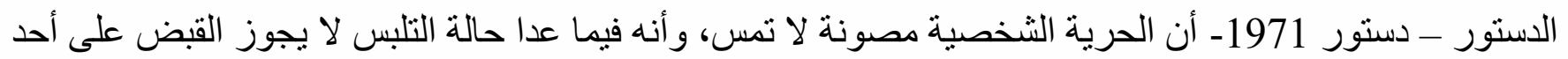

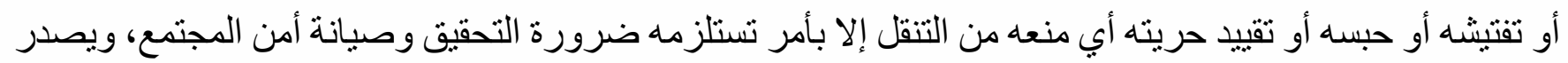

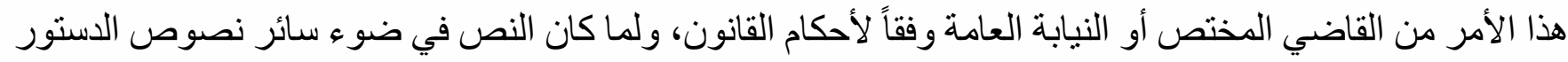
المنظمة للحقوق والحريات العامة وضماناتها، أن أوامر القبض على الأشخاص أو تفتيشهم أو حبسهم أو منعهم من التنقل و السفر أو تقييد حرياتهم بأي قيد دون ذلك هي إجر اءات جنائية تمس الحرية الثخصية التي لا يجوز تنظيمها إلا

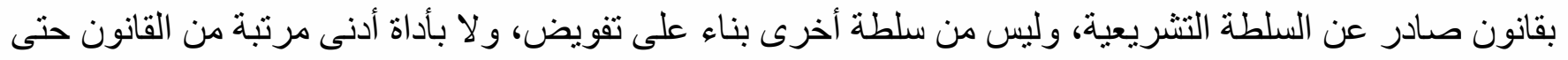

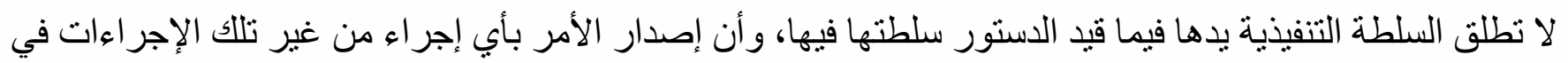

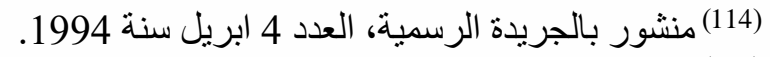
(115) د المهوى عبد الحميد العدل المهدى، مدى احتر ام حقوق الانسان عند مكافحة جر ائم الارهاب، رسالة دكتور اه، كلية الحقوق -جامعة 
غير حالة التلبس، لا يجوز إلا من القاضي المختص أو النيابة العامة، وفقا لقانون ينظم القو اعد الثكلية والموضوعية لإصدار هذا الأمر في ضوء الضو ابط التي وضعها الدستور نفسه باعتباره القانون الأسمى )(118). وجاء حكم المحكمة الدستورية العليا ليؤكد على المبادئ التي أقرها قضاء النقض، ويعلي من القيمة الدستورية لمبدأ الثر عية الإجرائية، حيث انتهت المحكمة الدستورية العليا بجلسة 2000/11/4 في الدعوى رقم 243 لسنة 21ق دستورية إلى عدم دستورية المادتين (8،8) من القرار بقانون رقم 97 لسنة 1959 بشأن جوازات السفر وأبرز ما

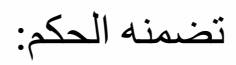
حق المواطن في استخر اج وحمل جواز السفر، لا يعد فحسب عنوانا لمصريته التي يشرف بها داخل وطنه وخارجه، بل يعكس فوق ذلك ر افداً من رو افد حريته الثخصية التي حفى بها الدستور. تعد حرية السفر من الحريات العامة التي لا يجوز تقييدها دون مقتضى مشروع، وقد عهد الدستور إلى السلطة التشريعية دون غير ها بتقرير هذا المقتضى، ولزام ذلك أن يكون تعيين شروط إصدار وثيقة السفر بيد هذه

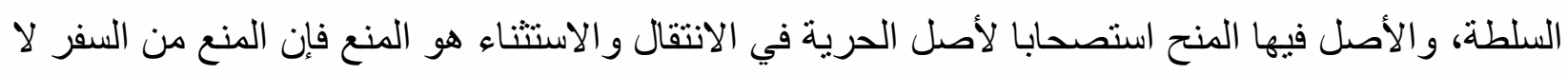
يملكه إلا قاض أو عضو نيابة عامة يعهد إليه القانون بذلك دون تدخل من السلطة التنفيذية. أن ما نصت عليه المادتين (8،11) من القرر بقانون 97لسنة2959،إنما تتمخض عن تتصل المشرع من وضع الأسس العامة التي تنظم موضو عات جو از ات السفر بأكملها، ومن ثم يكون مسلك المشر ع في هذا الثشأن مخالفاً اللاستور (119) 
المنع من السفر في المواد الجنائية

\section{محمد السعبد القز عة}

2 - الأساس القانوني للمنع من السفر بعد القضاء بعدم دستورية المادتين 8،8 من قانون جوازات السفر: وترتب على صدور هذا الحكم حدوث فراغ تشريعي فيما يتعلق بالمنع من السفر في المو اد الجنائية، ولم يتذخل هن

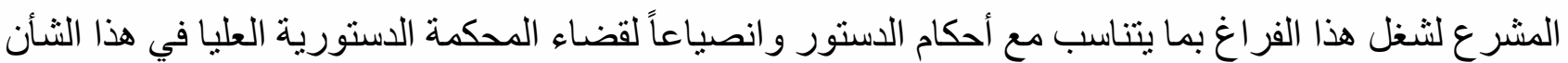
غير أن هناك رأي فقهي أسس المنع من السفر في المو اد الجنائية بعد القضاء بعدم دستورية المادتين 8، 11، من القرار بقانون 97لسنة 1959 بشأن جواز ات السفر إلى أنه من ضمن الإجر اءات التحفظية التي تتمثل في قرار قضائي يصدر عن سلطة التحقيق الابتدائي أو المحاكم، ويتضمن وضع شخص معين أو مال أو شيء محدد بصفة مؤقتة تحت

بد القضاء(120).

وبالتالي اعتباره من الإجر اءات التحفظية الجائز اتخاذها من قبل النائب العام استناداً الى المادة 208 مكرر(أ) من قانون الإجر اءات الجنائية والتي تقضى أنه في الأحوال التي تقوم فيها من التحقيق أدلة كافية على جدية الاتهام إذا قدرت النيابة العامة أن الأمر يقتضى اتخاذ تدابير تحفظية على أموال المتهم بما في ذلك منعه من التصرف فيها أو إدارتها، وقياساً على منع التصرف في الأمو ال يمنع المتهم من السفر باعتباره من الإجر اءات التحفظية التي أطلقتها تلك المادة دون تحديد، ويستفاد من ذللك حق النيابة العامة وضع قيود على حرية السفر إذا استلزمت ضرورة التحقيق ذللك مع مر اعاة أن تكون هذه القيود وفقا لأحكام القانون(121).

وفي حين ذهب رأي فقهي و أؤيده إلى وصف القرارات الصادرة من النيابة العامة بالمنع من السفر استناداً إلى نص المادة 208 مكرر(أ) من قانون الإجر اءات الجنائية مفتقرة إلى الثرعية، ولا يجوز الاستناد إليها؛ لأن النص لم لم يذكره صر احة، كما أن تفسير النص باعتبار أن مدلول التدابير التحفظية يشمل المنع من السفر هو تفسير تعسفي للنص ؛ذللك أن المنع من السفر بحسبانه من الإجر اءات الخطيرة الماسة بالحرية الثخصية لا يفترض ضمناً، بل يجب النص بله عليه صر احة؛ فهو يماثل من حيث الأثر القبض والحبس الاحتياطي ويجب أن ينظمها القانون صر احة، ويلاحظ أن النص لم ينص إلا على حالات محددة تتصل بالمال لا بالمنع من السفر، فالثار ع لم يخول النيابة العامة سلطة إصدار

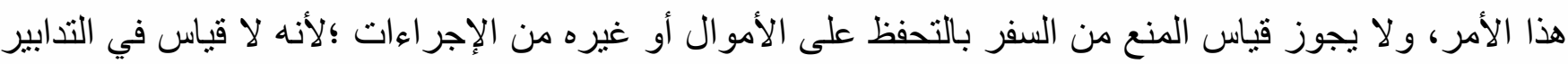
المنطوية على إجر اءات ماسة بالحرية الثخصية ولا يجوز المنع من السفر إلا بقانون(122). وقد حسم هذا الجدل بشأن جواز قياس المنع من السفر على المنع من التصرف في الأمو ال استنادا إلى نص المادة 208 مكرر(أ)، وذلك بصدور القانون رقم174 لسنة 1998 والمنشور بالجريدة الرسمية العدد(51) مكرر في

(120) د محمد على سويلم، الاوامر التحفظية في الاجراءات الجنائية ـدراسة مقارنة، دار المطبوعات الجامعية، الاسكندرية، 2020، ص201. دمد

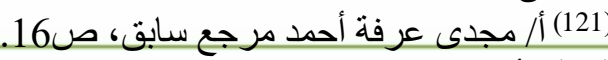

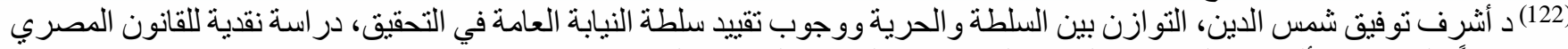

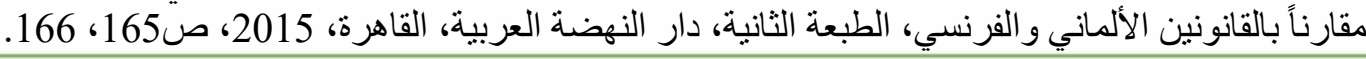


المنع من السفر في المواد الجنائية

\section{محمد السعبد القز عة}

1998/12/20 وتحديده بأن الإجر اءات التحفظية الو اردة بالمادة سالفة الذكر هي موجهة ضد الأموال دون الأشخاص، وبالتالي لا محل للاجتهاد و القياس مع صر احة النص .

و على الرغم من ذلك فقد درجت النيابة العامة على إدر اج العديد من المتهمين على قو ائم الممنو عين من السفر، ونظمت المادة (407) من التعليمات العامة للنيابات كيفية الإدر اج في قو ائم الممنوعين من السفر، ولكن وجئ واجب التنويه بأن التعليمات العامة للنيابات لا تصلح بحال مصدر الإجر اءات الجنائية، وكل نص في تللك المنشورات أو التعليمات يصدر في حدود السلطة الإدارية للوزير أو النيابة العامة ويقتصر نطاقه على تنظيم سير العمل؛ لذلك قضى بأن (أنه لا

يصلح الاعتداد بالتعليمات في مقام تطبيق القانون..)(123)

ثانيًا المنع من السفر في التثريع الفرنسي:

تضمن قانون الإجراءات الجنائية الفرنسي(124) إجر اء المنع من السفر باعتباره من القيود المهمة على حرية الفرد

الثخصية ضمن ما يسمى بالرقابة القضائية والذي أقر بالقانون رقم 70/643 بتاريخ 17 يوليو 1970 و الذي يمثل

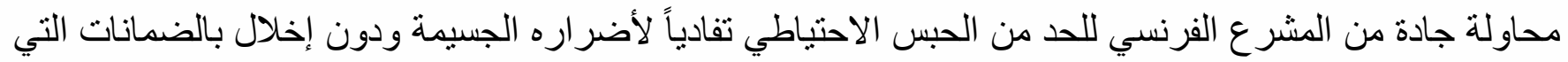
يوفرها هذا الإجراء لحرية البريء(125)، ونظراً لحساسية الإجراءات الواردة في نظام الرقابة القضائية ولطابعها الاستثنائي فقد أناط إصدار الأو امر الخاصة بالمنع من السفر بقاضي التحقيق أو قاضي الحريات و إطلاق السر اح، فقد قررت المادة 138 من قانون الإجر اءات الجنائية الفرنسي أن الرقابة القضائية يتم الأمر بها من قاضي التحقيق أو قاضي التي

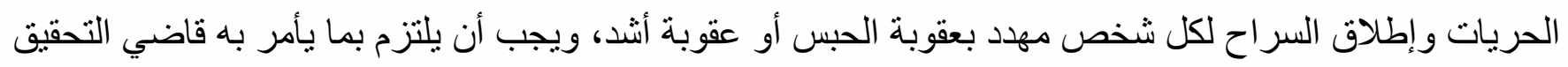
أو قاضي

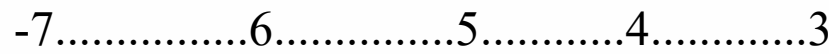

تسليم الأمين القضائي أو مركز الثرطة أو الدرك كل الوثائق الثثوتية وجواز السفر مع إعطائه وثثية مؤقتة تثبت هو يته (المادة 138إجر اءات جنائية فرنسي) من خلال البند السابع من تلك المادة يتضح أن المدرج تحت نظام الرقابة القضائية ملتزم بتسليم جواز السفر باعتباره أحد الوثائق الثبوتية، وهو عبارة عن مستند صادر عن السلطة الإدارية يحدد هوية الثخص ويأذن له بمغادرة الإقليم الوطني(126)، وبالتالي لا يستطيع مغادرة فرنسا حال تسليمه جواز سفره للسلطة التي حددها نص المادة 138 إجر اءات جنائية فرنسي.

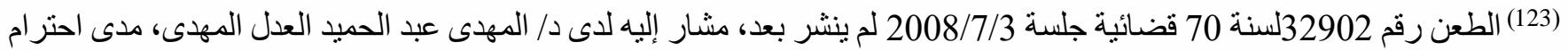

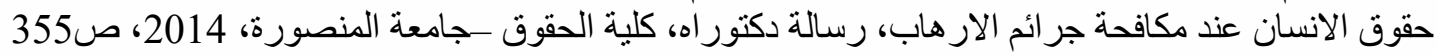

(124) الصنادر في 1958.

${ }^{(125)}$ Pierre Chambon, Le juge d'instruction: theorie et pratique de la procedure, Dalloz, 15 Avril, 1997, p.298

(126) M.Jean Rivero Et M.Jacques Robert, Cours de Libertés Publiques, Paris, 1969-1970.P 447 


\section{محمد السعبد القز عهة}

و أتصور أن المشرع الفرنسي كان أكثر توفيقاً من نظيره المصري فيما يتعلق بالمنع من السفر على أكثر من

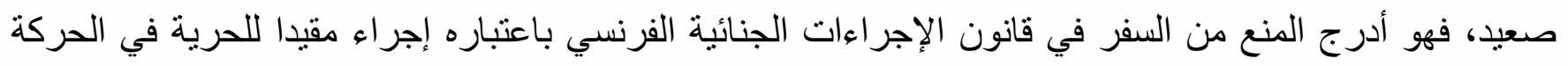

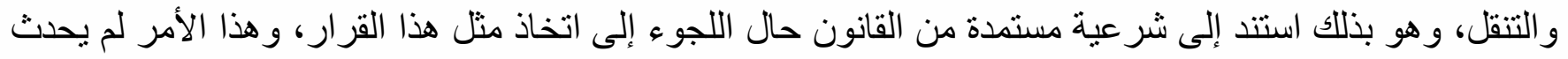
في التشريع المصري فلا يوجد ثمة نص في قانون الإجر اءات الجنائية المصري متعلق بتنظيم المنع من السفر رغم

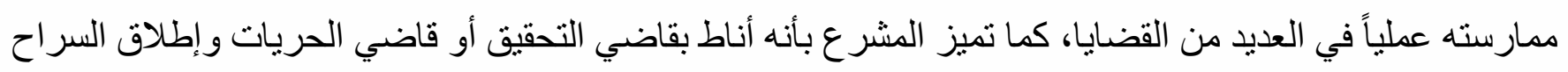

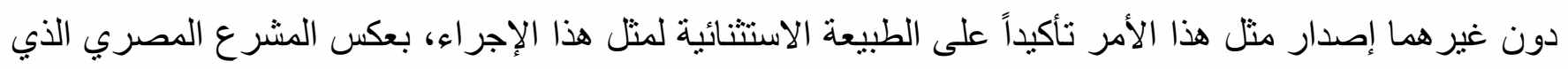

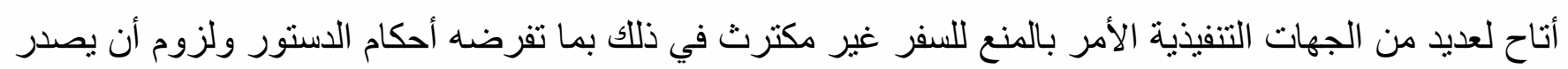
هذا الإجر اء من قاضي التحقيق أو النيابة العامة. ثالثاً _المنع من السفر في التشريع الكويتي: تتحصر النصوص القانونية التي تمس الحق في السفر، فيما نص عليه قانون المر افعات الكويتي رقم 38 لسنة

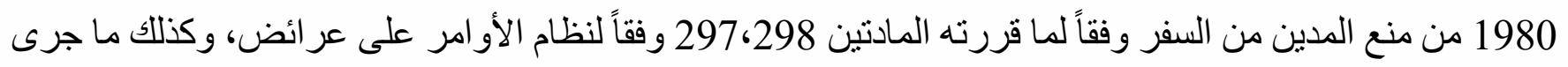

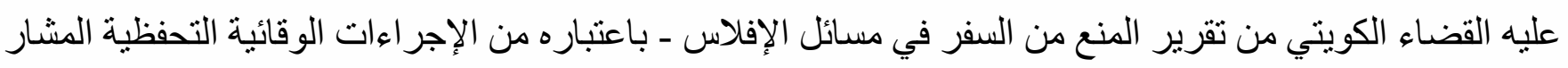

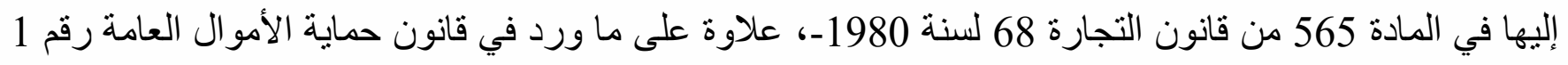

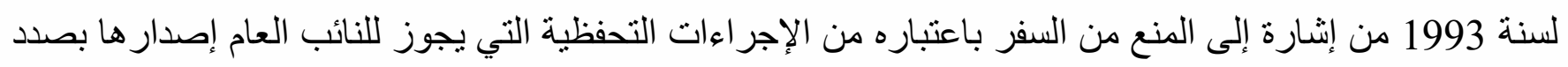

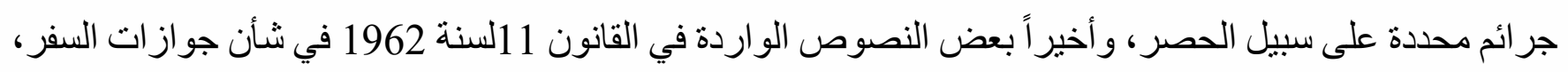
وبخلاف ذللك لا توجد نصوص تثريعية تشير إلى إجراء المنع من السفر صراحة، لاسيما في قانون الإجراءات

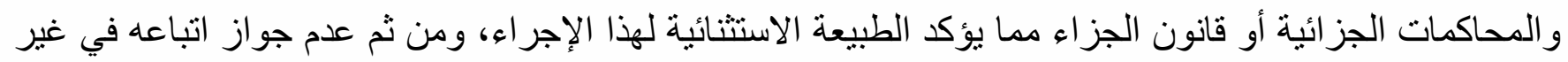

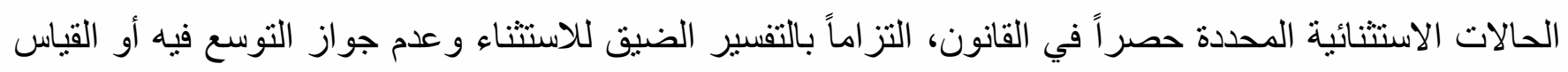
عليه(127). وقرر قانون الإجر اءات الجزائية رقم 17لسنة 1960 وتعديلاته: يعتبر المنع من السفر في قانون الإجراءات الجزائية الكويتي من قبيل الإجراءات التحفظية، وقد نص عليها الشررع في الفصل الثاني من الباب الثاني من هذا القانون المتعلق بالتحريات و التحقيق الابتدائي، لكن تنبغي الإشارة إلى أن المشرع قرر في المادة 37 من هذا القانون (يجوز في التحريات وفي التحقيق البحث عن الأدلة المادية و الثفوية المتعلقة بالجريمة بالوسائل التي نظمها هذا القانون، كما يجوز الالتجاء الى أب وسيلة أخرى إذا لم تكن فيها مخالفة

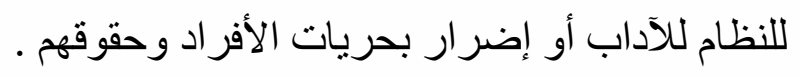
رابعاً المنع من السفر في التشريع العماني(128): 
قرر المشرع العماني في قانون الإجر اءات الجزائية المنع من السفر كأحد الإجر اءات التحفظية التي يمكن أن تتخذ في مواجهة المتهم وذلك من خلال المادة 52 مكررا والتي جاء فيها (للمدعى العام أو من يقوم مقامه أن يصدر أمر آ الأ بالمنع من السفر إذا وجدت دلائل كافية على اتهام شخص بارتكاب جناية أو جنحة معاقب عليها بالسجن

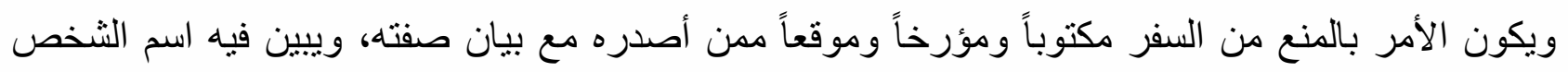

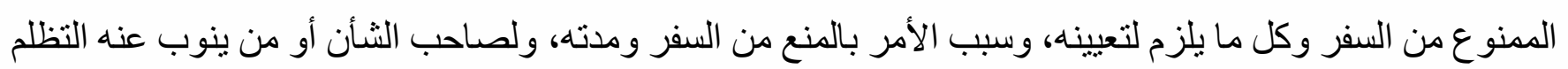
من أمر المنع من السفر أمام محكمة الجنح المستأنفة منعقدة في غرفة المشورة، و عليها الفصل في التظلم خلال ثلاثة

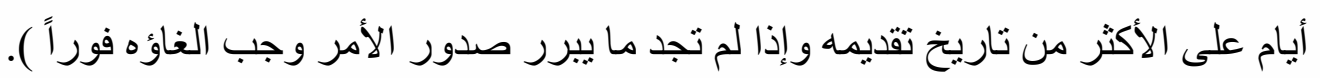

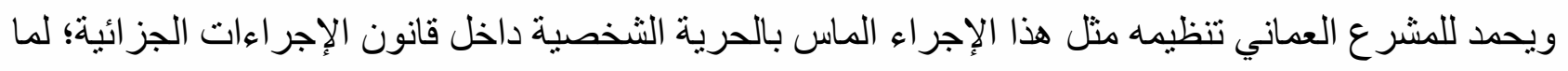

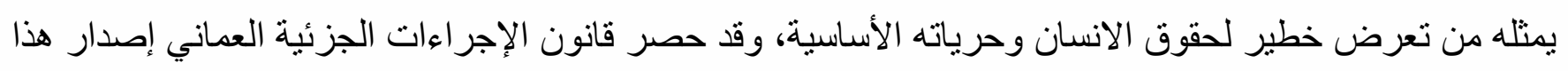
الأمر في المدعى العام أو من يقوم مقامه وذللك شريطة أن تكون هناك أدلة كافية على اتهام الصادر بحقة أمر المنع من الصن

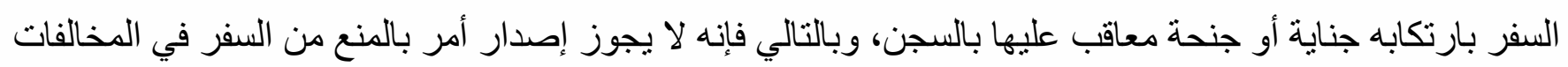
أو الجنح المعاقب عليها بالغر امة .

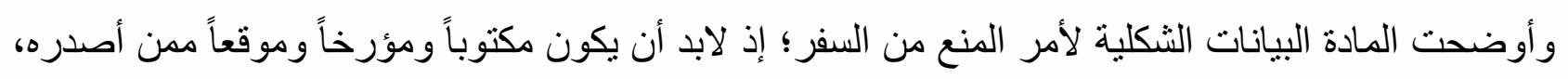
كذللك لابد أن يشمل أمر المنع من السفر اسم الثخص الممنوع من السفر وسبب الأمر بالمنع من السفر ، ومعنى ذللك أنه

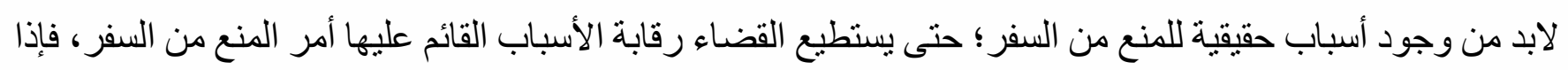

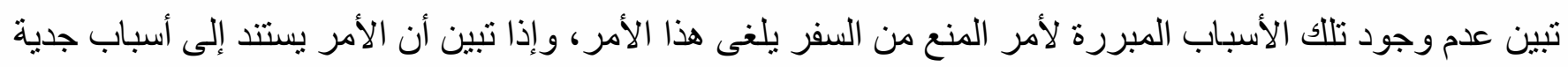
اعتبر اتخاذه صحيحاً(129)، وكذلك لابد من بيان مدة المنع من السفر.

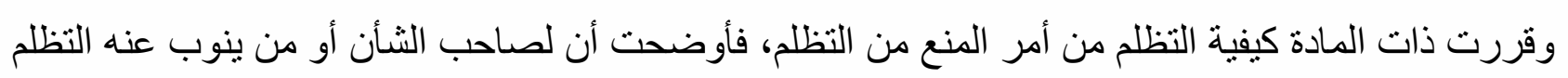
من أمر المنع من السفر وذللك أمام محكمة الجنح المستأنفة منعقدة في غرفة المشورة، و ألزمت ذات ذات المادة المحكمة فئة الفصل في التظلم بالمنع من السفر خلال ثلاثة أيام على الأكثر من تاريخ تقديمة، و إذا لم تجد المحكمة ما يبرر هذا الأمر وجب إلغاؤه فوراً.

خامساً: المنع من السفر في التشريع السعودي: وال: كفلت أنظمة المملكة العربية السعودية من خلال نظامها الأساسي للحكم و الذي نص في مادته السادسة و الثلاثين

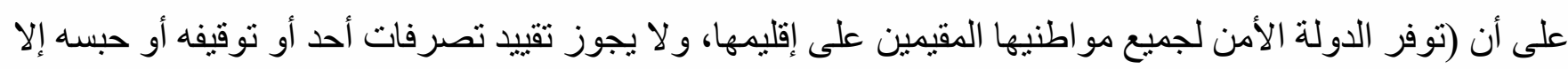
بموجب أحكام النظام ) وقد أكدت الفقرة الثانية من المادة السادسة من نظام وثائق السفر الصادر بالمرسوم الملكي رقم

(129) د محمد على سويلم، الاوامر التحفظية في الاجر اءات الجنائية ـدر اسة مقارنة، دار المطبوعات الجامعية، الاسكندرية، 2020، ص ص68 
(24/21/5/28 1428هـ على أنه (لا يجوز المنع من السفر إلا بحكم قضائي أو بقرار يصدره وزير الداخلية

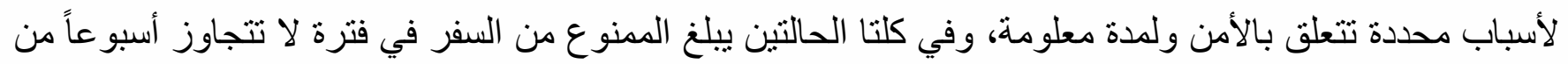
تاريخ صدور الحكم أو القرار بمنعه من السفر)(130).

(130) القاضي عبدالله بن عبد الصمد القبيسي دعوى المنع من السفر، ورقة عمل مقدمة للعرض على الاجتماع الدوري لرئيس وقضاة

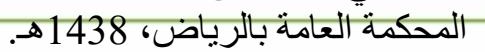




\section{محمد السعبد القز عهة}

\section{المبحث الثالث}

\section{صور المنع من السفر في الاعوى الجنائية}

تمهيخ وتقسيم:

تعرف الدعوى الجنائية بأنها(مجمو عة من الإجر اءات الجنائية يحددها القانون وتستهدف الوصول إلى حكم قضائي

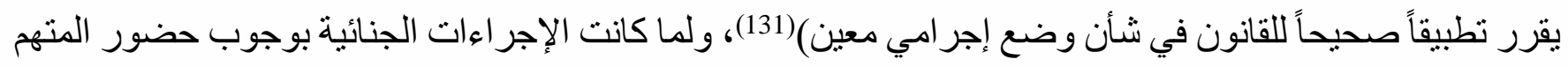

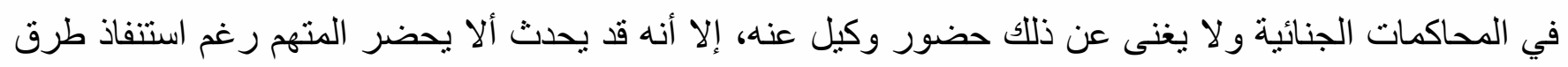

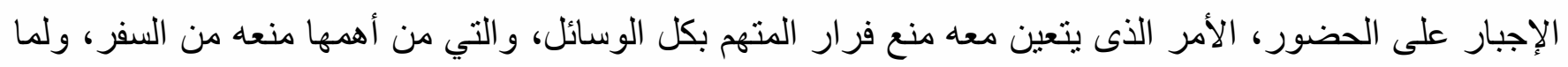

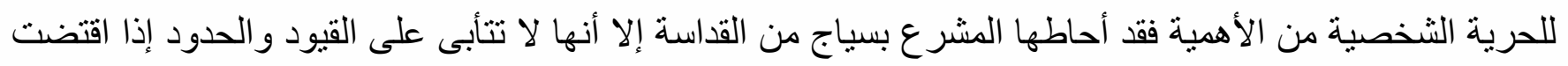

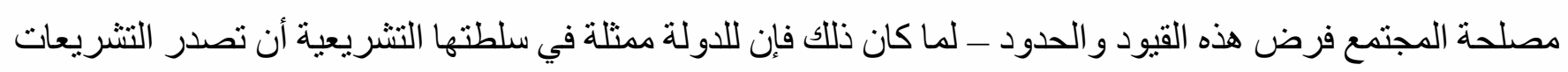

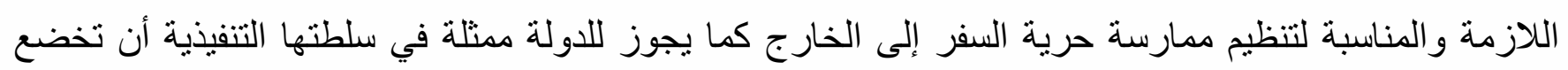
ممارسة هذه الحرية لنظام الترخيص(132).وبالرغم من عدم تنظيم المنع من السفر في قانون الإجراءات الجنائية

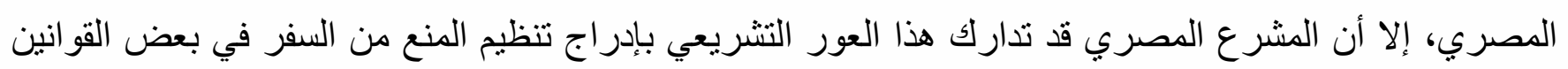

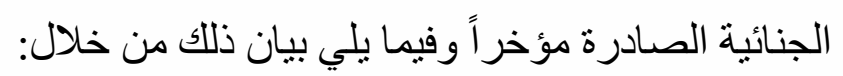

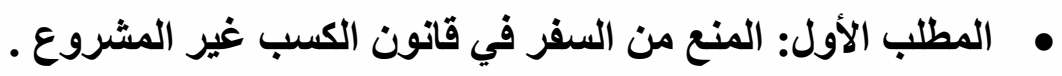

• المطلب الثاني: المنع من السفر في قانون مكافحة جرائم تقنية المعلومات. • المطلب الثالث: المنع من السفر في تثريعات مكافحة الإرهاب. المطلب الأول

المنع من السفر في قانون الكسب غير المشروع

جاء قانون الكسب غير المشروع رقم 62 لسنة 1975 غير متضمن أب إثارة لتقييد حرية السفر بالنسبة للخاضعين

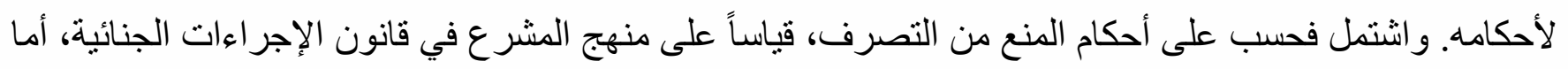

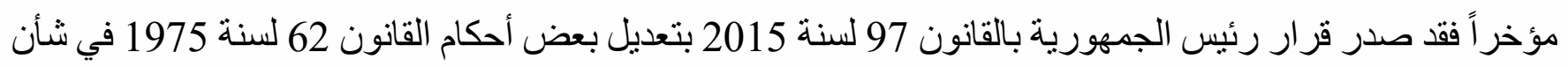

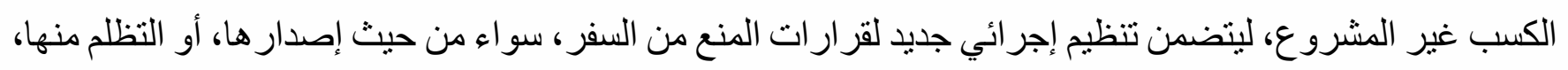

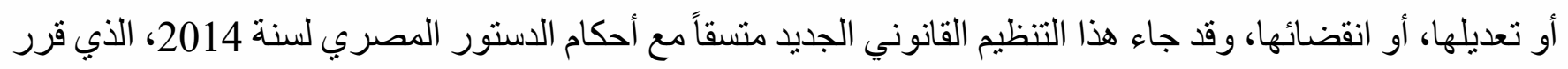

(131) د محمود نجيب حسنى، شرح قانون الاجر اءات الجنائية، ج1، دار النهضة العربية، القاهرة، 2013، ص68

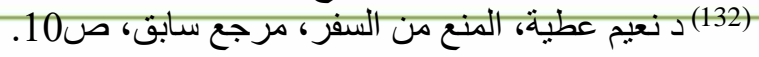




\section{محمد السعيد القز عة}

في المادة 62 منه على ضمان حرية المو اطنين في التنقل و عدم منعهم من مغادرة إقليم الدولة إلا بأمر قضائي مسبب ولمدة محددة(133).

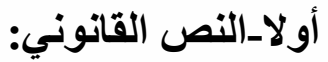

قررت المادة 13مكرر من قانون الكسب غير المشروع رقم 62 لسنة 1975و المعدل بالقانون 97 لسنة 2015 بأن (يجوز للهيئة المختصة بالفحص و التحقيق عند الضرورة أو عند وجود أدلة كافية على جدية الاتهام في جناية الكسب غير المشروع أو في إخفاء الأموال المتحصلة منها، أن تطلب من النيابة العامة منع المتهم من السفر إلى خارج البلاد أو وضع اسمه على قو ائم ترقب الوصول، وللمدنوع من السفر أو المدرج على قو ائم الترقب أن يتظلم من هذا الأمر التر أمام محكمة الجنايات المختصة خلال خمسة عشر يوماً من تاريخ علمه به، فإذا رفض تظلمه فوله فله أن بتقام بتظلم جديد كلما انقضت ثلاثة أثهر من تاريخ الحكم برفض التظلم، ويحصل التظلم بتقرير يودع قلم كتاب محكمة الجنايات المختصة، و على رئيس المحكمة أن يحدد جلسة لنظر التظلم يعلن بها المنظلم و النيابة العامة، و على المحكمة أن تفصل في التظلم مدة لا تجاوز خمسة عشر يوماً من تاريخ التقرير به بقرار مسبب بعد سماع أقوال المتظلم وعضو النيابة

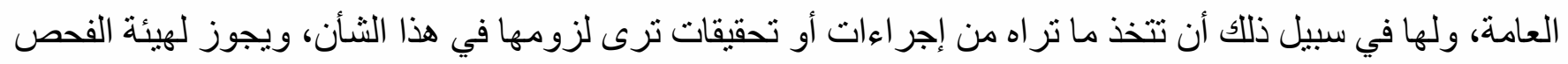
و التحقيق المختصة في كل وقت أن تطلب من النيابة العامة السفر أو ترقب الوصول لمدة محددة إذا دعت الضرورة لذللك، وفي جميع الأحوال يسقط أمر المنع من السفر ويزول أثره بصدور قرار بأن لا وجه لإقامة الدعوى الجنائية أو بانقضاء الدعوى الجنائية بالتصالح أو بصدور حكم نهائي فيها بالبر اءة أيهما أقرب)(134). وجاء في المادة الثانية من هذا القانون بأنه (يعد كسباً غير مشروع كل مال حصل عليه أحد الخاضعين لأحكام

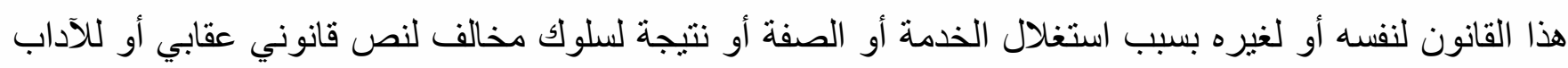

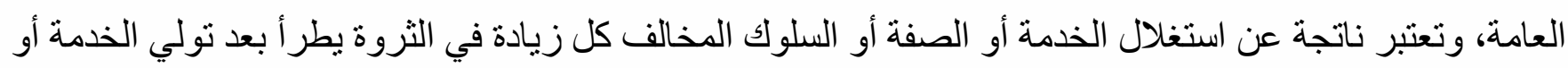

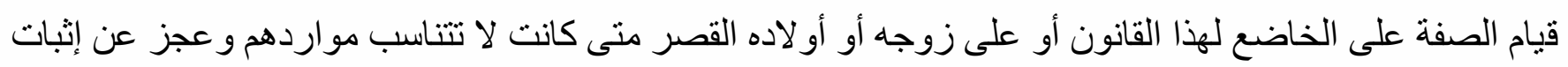
مصدر مشروع لها) .

و عرفت محكمة النقض الكسب غير المشروع بأنه (كل مال تملكه الموظف العام أو من في حكمه فصار ضمن ذمته المالية عنصر اً من عناصر ها باستغلال ما تسبغه عليه وظيفته أو يخوله مركزه من إمكانيات تطوع له له الاجتر اء هاء

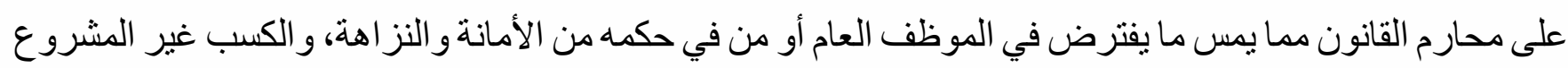

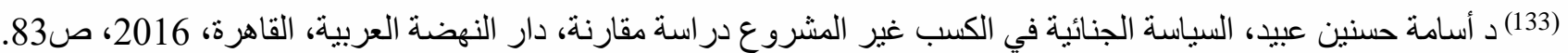

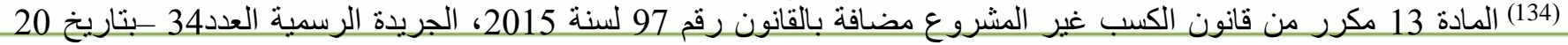
اغسطس 2015. 


\section{محمد السعيد القز عة}

لا يعدو صورتين الأولى و هي التي يثبت فيها في حق الموظف العام ومن في حكمه أيا كان نوع وظيفته استغلاله بالفعل لأعمال أو نفوذ أو ظروف وظيفته أو مركزه وحصوله بالفعل على مال مؤثم نتيجة لهذا الاستغلال. و الثنانية هي لا يثبت فيها هذا الاستغلال الفعلي على الموظف العام أو من في حكمه، ولكن يثبت أن لديه في ماله زيادة عجز عن إثبات مصدر ها، وفي هذه الحالة يتعين أن يكون نوع وظيفة الموظف مما يتيح له فرص الاستغلال على حساب الدولة أو على حساب الغير (135).

\section{ثثانياً- شروط المنع من السفر في قضايا الكسب غير المشروع:}

يعد طلب المنع من السفر فيما يتعلق بقضايا الكسب غير المشروع من قبيل الإجراءات التحفظية التي قررها المشرع للعديد من الاعتبار ات إلا أن سلطة النيابة العامة في هذا الأمر ليست مطلقة؛ لأن في إجر اء المنع من السفر مساس بالحرية الثخصية المصونة وفقاً لنصوص الدستور، وقد أكد على ذلك قضاء النقض والذي قرر بأن الحرية الثخصية مصونة لا تمس، وفيما عدا حالة التلبس لا يجوز القبض على أحد أو تفتيثه أو حبسه أو تقييد حريته بأي قيد

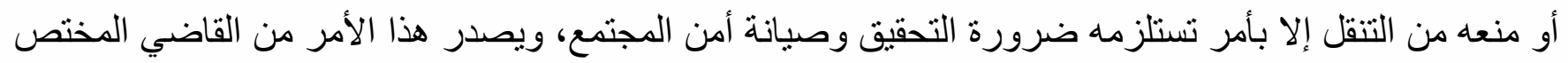

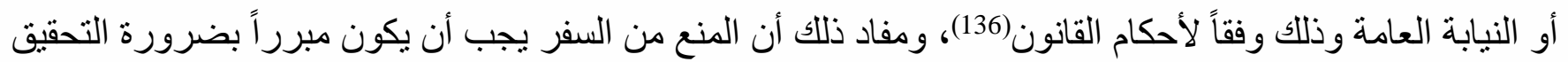

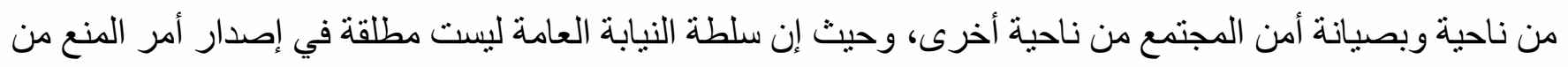
السفر، ووفقا لما ورد في نص المادة 13 مكرر من قانون الكسب غير المشروع فيشترط:

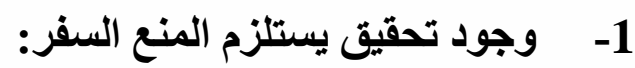

رغم أن قانون الإجر اءات الجنائية لم يتضمن ما يفيد تنظيم المنع من السفر، وهو ما يمثل فر اغاً تشريعياً أدعو المشرع المصري إلى تداركه، إلا أن هناك بعض القوانين الجنائية جاءت منظمة لإجر اء المنع من السفر ومن بينها قانون الكسب غير المشروع و الذى أتاح للنيابة العامة اتخاذ مثل هذا الإجر اء في وجود ضوابط منها أن يكون هنالك تحقيق، فإذا لم يكن هناك تحقيق مفتوح فلا يمكن اتخاذ مثل هذا الإجر اء، كما أنه لا يكفي وجود تحقيق فقط لمنع المتهم

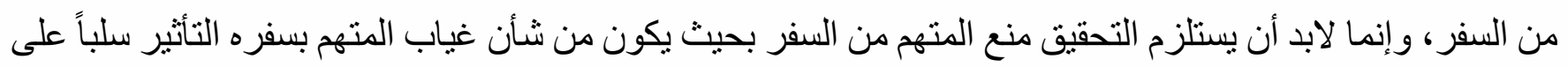
مجريات التحقيق، لذلك قضي بأن (المنع من التنقل داخل البلاد أو خارجها من الإجر اءات التي تمثل قيداً على الحرية الثخصية التي من عناصر ها الحرية في التنقل، ويجب أن تكون هنالك ضرورة لدى التحقيق مع الثخص تستلزم منعه من السفر، بحيث تكون مرتبطة بمصلحة التحقيق أو صيانة أمن المجتمع)(137). 


\section{محمد السعبد القز عة}

2- - 2 - وجود جدية في الاتهام:

يعد المنع من السفر من قبيل الإجر اءات التحفظية موقوت بتحقق الغاية منه ؛و لأن هذا الإجر اء يمس حق أصيل للإنسان وحرية من حرياته الأساسية لذلك اشترط لصحته أن يقوم على أسباب جدية، تتمثل في وجود أدلة كافية وقر ائن مادية من شأنها أن تؤدي إلى جدية الاتهام لا يستلزم الأمر أن تكون الأدلة قاطعة الثبوت بل بلى يكفي فيها أن تكون تللك الأدلة كافية بما يستتبع معه جدية الاتهام لذلك قضت المحكمة الإدارية العليا بأن (لا يتحتم لصحة قرار المنع من السفر

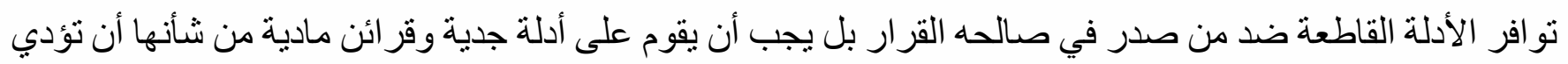

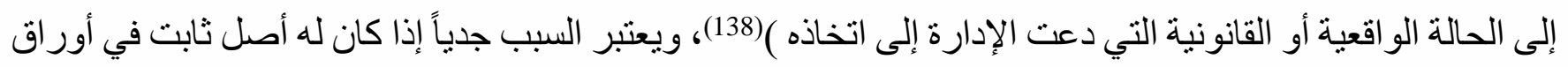
الدعوى؛ وبالتالي إذا لم يكن هنالك سبب جدي فإن القرار بالمنع من السفر يكون غير سند من القانون ؛لذلك قضي بأن إنان (ومن حيث البين من ظاهر الأوراق أن السبب الذي قام عليه القرار الطعين لا يعدو أن يكون قولاً مرسلاً لم تقدم الجهة

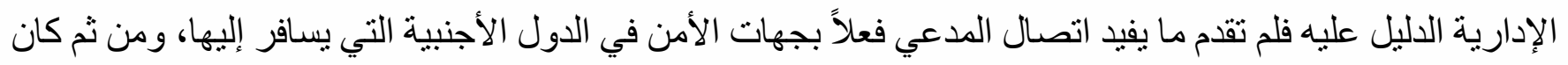
هذا القول لا يرقى إلى مصاف الذي يمكن أن يستند إليه القرار المطعون فيه، الأمر الذى يكون معه القرار قد صدر فاقدا لركن السبب ويرجح معه إلغاؤه)(139). 3- 3 أن يكون قرار المنع مؤقتاً: يتسم قرار المنع من السفر بكونه قراراً احتياطياً مؤقتاً غير فاصل في الموضوع، ومعنى ذللك أنه لا يعتبر جز اء

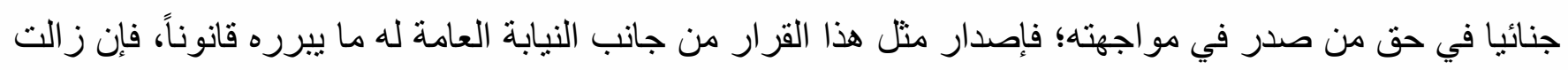

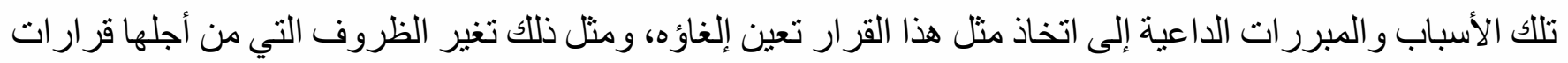

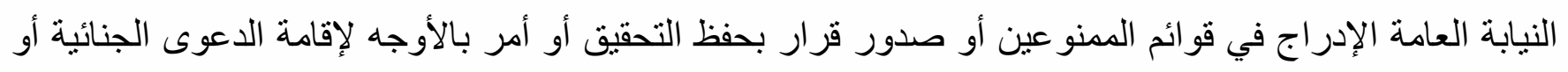
انقضاء الدعوى الجنائية صلحاً أو تقضي فيها بالبر اءة. ثالثاـ التظلم من المنع من السفر في الكسب غير المشروع: تقضي المادة 13 مكرر من قرار رئيس الجمهورية 97 لسنة 2015 بتعديل بعض أحكام القانون62لسنة 1975 في شأن الكسب غير المشروع بأن (.... وللممنوع من السفر أو المدرج على قو ائم الترقب أن يتظلم من هذا الامر أمام

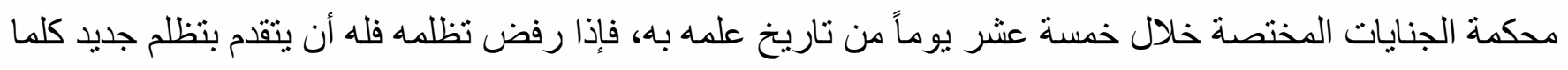
انقضت ثلاثة أثنهر من تاريخ الحكم برفض التظلم، ويحصل التظلم بتقرير يودع قلم كتاب محكمة الجنايات المختصهة،

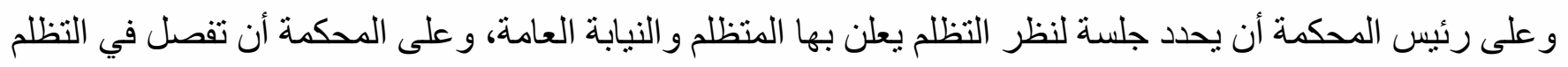

(138) الطعن رقم 2739 لسنة 29 ق، ادارية عليا، جلسة 1984/4/21، المكتب الفنى ـ مجموعة المبادئ القانونية التى قررتها المحكمة

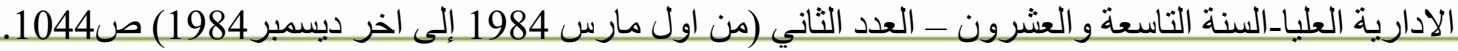

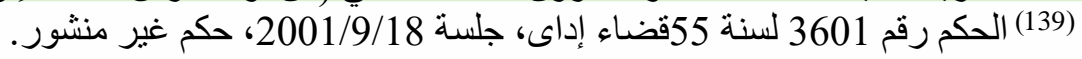


المنع من السفر في المواد الجنائية

\section{محمد السعبد القز عة}

مدة لا تجاوز خمسة عشر يوماً من تاريخ التقرير به، بقرار مسبب بعد سماع أقو ال المتظلم و عضو النيابة العامة .....).

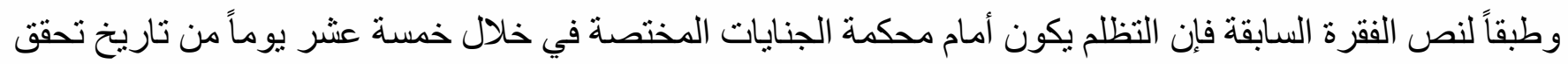
علمه بقرار المنع من السفر، وله في حالة رفض التظلم من قرار منعه من السفر أن بتقدم بتظلم جديد بعد مرور ثلاثة

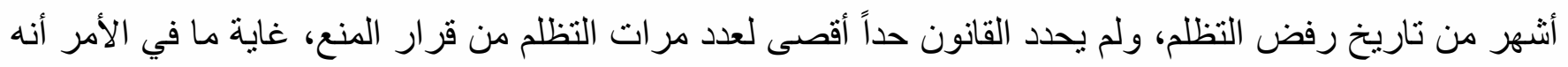

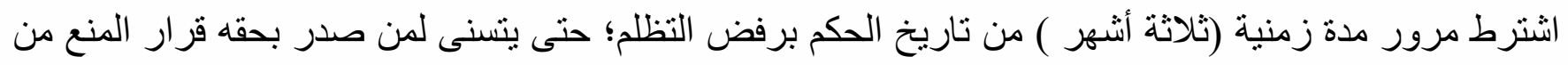
السفر أن يتقدم بتظلم آخر.

غير أنه يؤخذ على المشرع المصري عقده الاختصاص بنظر التظلم بالمنع من السفر لمحكمة الجنايات المختصة

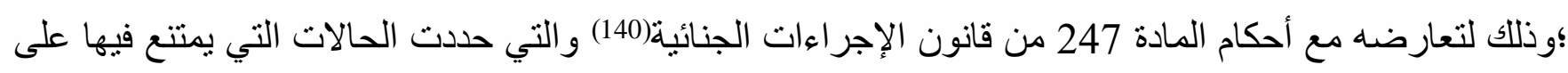
القاضي نظر الدعوى الجنائية لما بينهاو بين وظيفة القضاء من تعارض، ومن بينها أن يكون القاضي قد قام في الدعوى لئي بعمل من أعمال التحقيق والإحالة، وأساس وجوب امتناع القاضي عن نظر الدعوى هو قيامه بعمل يجعل له رأياً في

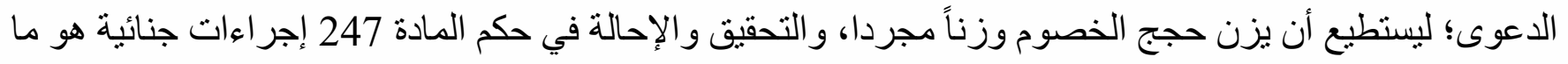
يجريه القاضي أو يصدره في نطاق تطبيق قانون الإجر اءات الجنائية بصفته سلطة تحقيق أوحكم(141)، لذلك قضى بأن النان (لما كانت المادة العاثرة من القانون 62 لسنة 1975 في شأن الكسب غير المشروع قد ناطت بهيئات الفحص و التحقيق بإدارة الكسب غير المشروع أن تأمر بمنع المتهم أو زوجته أو أو لاده القصر من التصرف فئن في أموات الهم، وأن تعرض

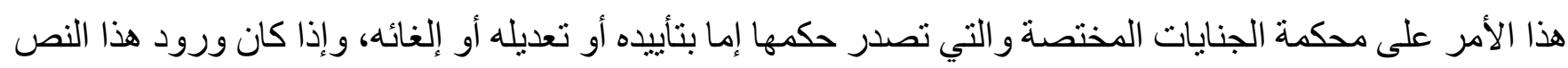
في قانون الكسب غير المشروع لا يغير من طبيعته كنص من النصوص المتعلقة بالإجر اءات الجنائية ومن ثم فإن الحكم الذى تصدره محكمة الجنايات في هذا الثأن يعتبر من أعمال التحقيق في حكم المادة 247 من قانون الإجر اءات الجنائية،

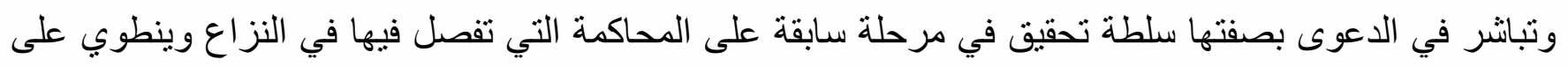
إظهار رأيها بأنها اقتتعت بقيام أو عدم قيام الدلائل الكافية على جدية الاتهام بالجريمة، ومن ثم يتعارض مع ما ما يتحتم

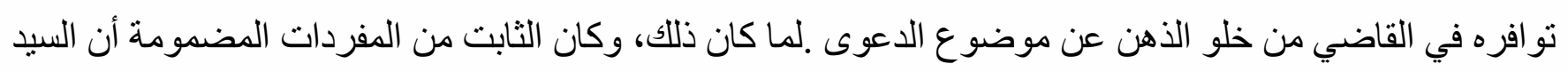

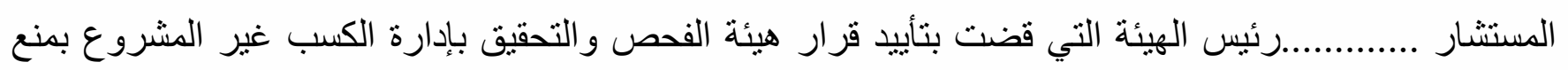
الطاعن من التصرف في أمو اله هو نفسه رئيس المحكمة التي أصدرت الحكم المطعون فيه، ومن ثم فإن الحكم المطعون

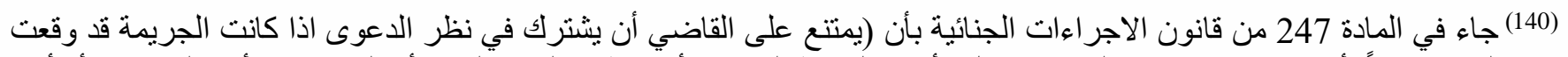

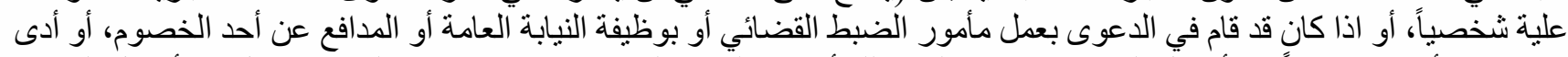

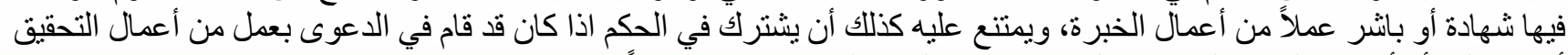

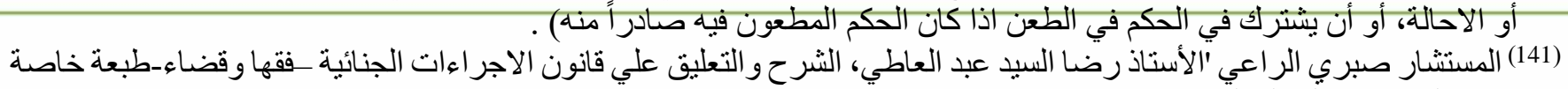

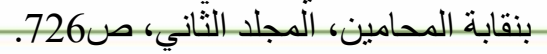


فيه يكون باطلاً لصدوره من هيئة فقد رئيسها صلاحيته بما يتعين نقضه والإعادة بغير حاجة إلى بحث سائر أوجه الطعن)(142).

ووفقاً لقضاء النقض السابق فإن ما يسري على المنع من التصرف في الأمو ال يسرى على منع السفر باعتبار أن كلا الإجر اءين من قبيل الإجر اءات التحفظية، وبالتالي فإن انعقاد الاختصاص لمحكمة الجنايات للنظر في التظلم بالمنع من السفر لهو أمر مؤثر في سلامة المحكمة الأمر الذى يتعين معه التدخل من جانب المشر علتلافي هذا العور التشريعي.

\section{رابعا- إجراعات التظلم في أمر المنع من السفر في قضايا الكسب غير المشروع:}

نظمت المادة الثالثة عشر مكرر من قانون الكسب غير المشروع كيفية التظلم من أمر المنع من السفر في قضايا الكسب غير المشروع، على أن يحصل النظلم من خلال تقرير يودع قلم كتاب محكمة الجنايات المختصة خلال خمسة عشر يوماً من تاريخ العلم بقرار المنع من السفر، عقب ذلك يحدد رئيس المحكمة جلسة لنظر التظلم يعلن بها المتظلم و النيابة العامة، وعلى المككة أن تفصل في النظلم من أمر المنع من السفر خلال خمسة عشر يوماً من ناريخ التقرير

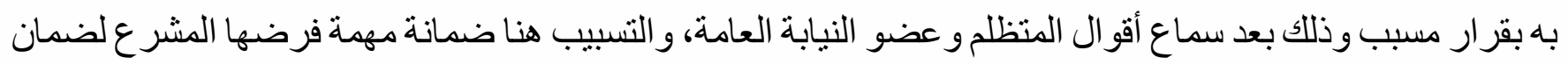
قيام القضاة بو اجب البحث، لذلك أجملت محكمة النقض علة التسبيب بقولها (أن غايته الأساسية الرقابة على عمل

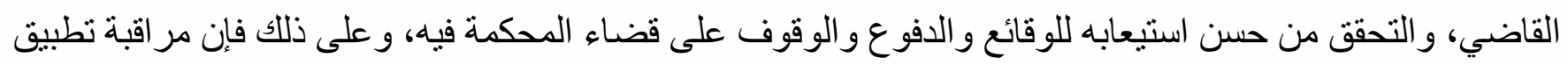
القانون وتقرير أو نفي الددعى به من مخالفة أحكامة لا تكون إلا من خلال النظر فيما أقام الحكم عليه قضاءه من وأسباب

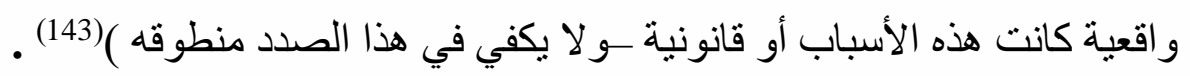
المطلب الثاني

\section{المنع من السفر في تشريعات مكافحة الإرهاب}

تعتبر ظاهرة الإرهاب كأسلوب إجرامي من أقدم أساليب العنف التي عرفها التاريخ البشري وأثندها وحشية وقسوة؛ حيث صارت من أكثر الجرائم خطورة على المجتمع الدولي بأكمله أفراد وحكومات، فتمارس هذه العمليات

$$
\text { الإرهابية لنشر الرعب و الاضطر ابات في الدول(144). }
$$

ومصطلح الإرهاب يعني العنف الثنديد الذي يبدر من فرد أو مجموعة من الأفراد، أو من تنظيم تجاه أفراد أو

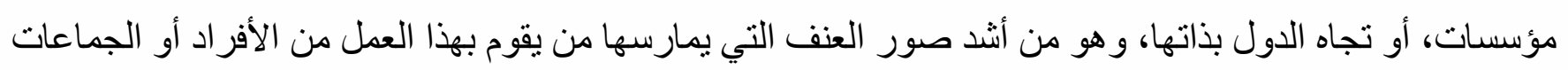

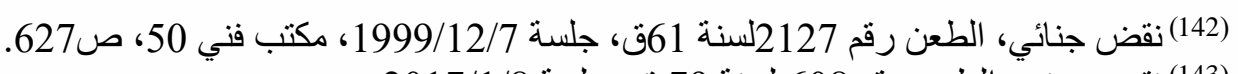

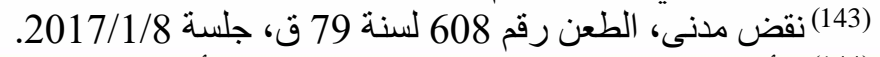

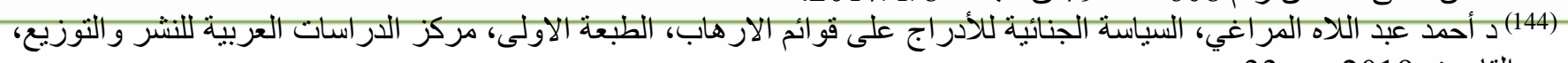

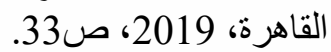


أو التنظيمات خارجاً عن إر ادة المجموع، وإن كان يمثل لدى البعض من هذه الجهات عملاًِيساعد على تنفيذ هدف من وجهة نظر هم يؤدي إلى صالح عام لا ير اهو اهم، ولو كان العمل خارجاً عن القو انين المحلية أو الأعر اف الدولية(145)

أما التعريف التشريعي للإرهاب فقد عرفته المادة 86 من قانون العقوبات المصري المضافة بالقانون

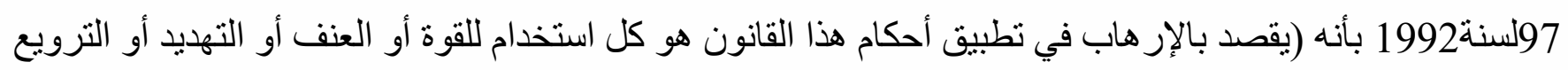

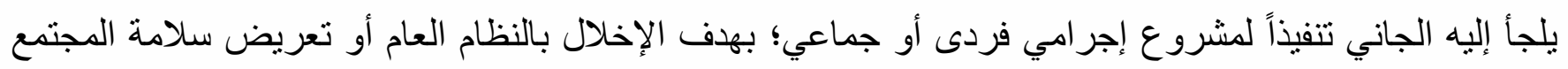

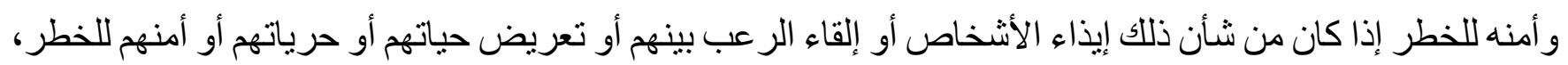

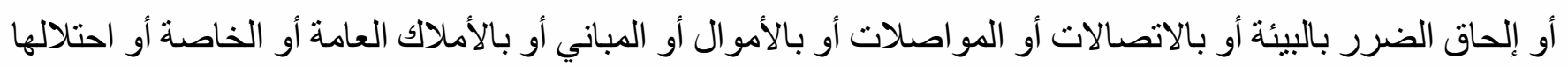

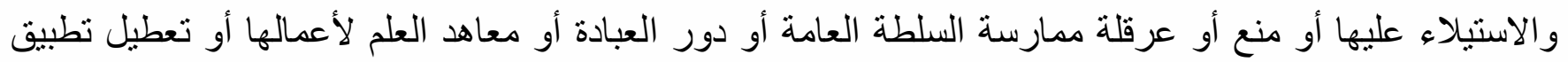
الاستور أو القوانين أو اللوائح ).

أما الإرهابي وفقاً للمادة الأولى من قرار رئيس الجمهورية بالقانون رقم 8لسنة 2015 هو (كل شخص طبيعي

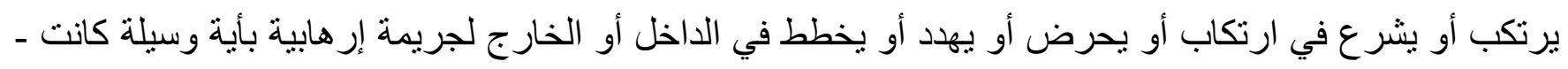

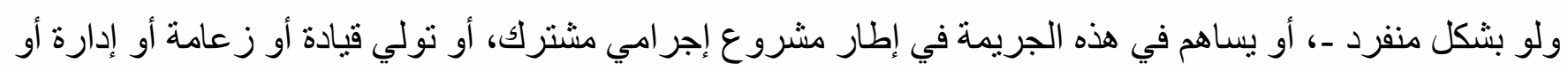

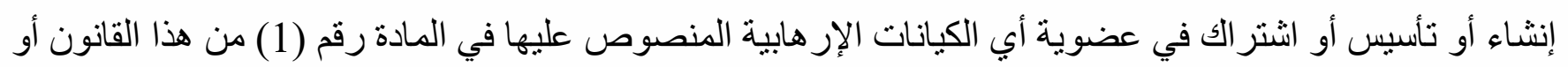
قام بتمويلها، أو ساهم في نشاطها مع علمه بذلك) .

\section{القرع الأول}

\section{المنع من السفر في قانون تمويل الإرهاب والكيانات الإرهابية}

أولاً -إجراءات الإدراج على قوائم الإرهاب:

قررت المادة الثالثة من هذا القانون بأن (تختص دائرة أو اكثر من دو ائر الجنايات بمحكمة استئناف القاهرة تحددها الجمعية العمومية للمحكمة سنوياً تكون منعقدة في غرفة المشورة، بنظر طلبات الإدر اج على قائمة الكيانات الإرهابية

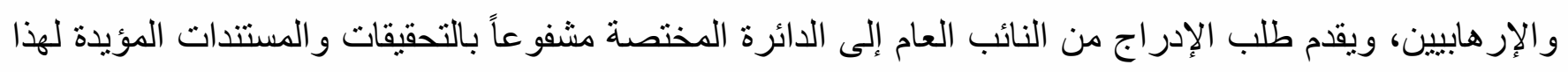

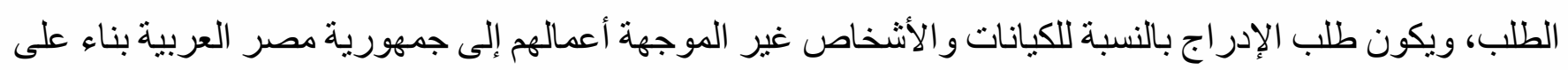

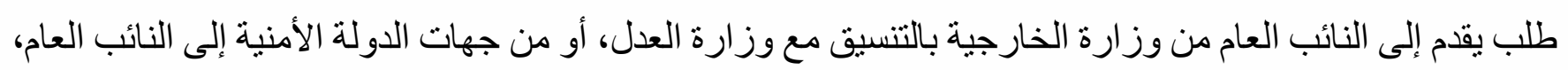
وتفصل الدائرة المختصة في طلب الإدر اج بقر ار مسبب خلال سبعة أيام من تاريخ تقديم الطلب لها مستوفياً المستندات

(145) المستشار /هشام عبد الحميد الجميلي، الموسو عة القانونية في جرائم التظاهر و التجمهر والارهاب و امن الدولة طو ارئ، نادي القضاة، 


\section{محمد السعيد القز عة}

اللازمة)، وتكون مدة الإدراج على قائمة الكيانات الإرهابية أو قائمة الإرهابيين لمدة لا تتجاوز ثلاث سنوات، فإذا

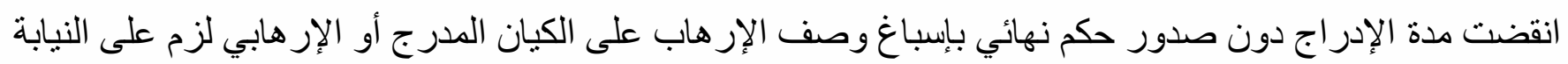

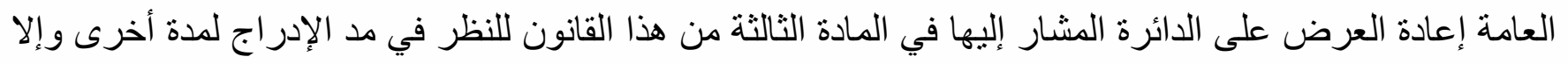

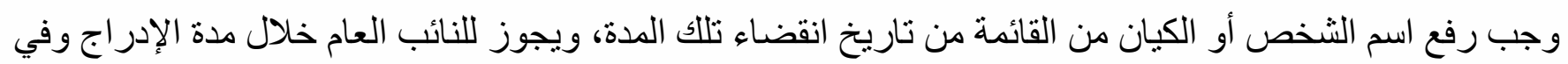
ضوء ما يبديه من مبررات أن يطلب من الدائرة المختصة رفع اسم الكيان أو الثخص الطبيعي من قوائم الإدراج، وأوجبت المادة الخامسة من هذا القانون نشر قرار الإدر اج على أب من القائمتين، وقرار مد مدتها، وقرار رفئ رفع اسم لأبي منهما في الوقائع المصرية.

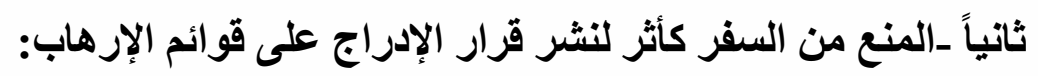
يترتب على نشر قرار الإدر اج في الوقائع المصرية بالنسبة للأشخاص الطبيعيين العديد من الاثار بقوة القانون

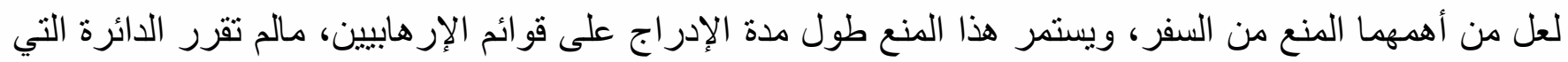
أصدرته خلاف ذلك.

فالأمر بالمنع من السفر يتم توقيعه كتدبير تبعي للحكم الصـادر بالإدر اج، وقد جاء القانون المصري مقتدياً في تلك الفلسفة بما استقر في القانون المقارن سواء الأمريكي أم الإنجليزي أم الألماني أم الفرنسي من إدخال مجموعة من لاهن Counter Terrorism And Security Act 2015 التدابير الجديدة في مجال الإرهاب مثل القانون الإنجليزي لسنة الذى وضع قيوداً على السفر إلى الخارج في الجزء الأول، الفصل الأول، وقانون العقوبات الفرنسي الذى قرر حظر الخروج من إقليم الدولة في المادة (224-1) مضافة بالقانون 1353لسنة السئة 2015 الإرهابية (146). فقررت المادة السابعة من قانون تتظيم الكيانات الإرهابية والإرهابين(147) بأن (تترتب بقوة القانون واستحداث المشرع الفرنسي بمقتضى المادة الأولى من هذا القانون تدابير جديدة لمكافحة الالتحاق بالتنظيمات الإر هابية لعدم كفاية الجز اءات الجنائية المقررة للالتحاق بها عبر حظر مغادرة الأر اضي الفرنسية للمو اطنين الذين يشتبه في كون سفرهم للخار ج بغرض الالتحاق بالتنظيمات على نشر قرار الإدراج، وطول مدته، الآثار التالية مالم تقرر الدائرة المنصوص عليها في المادة (3) من هذا

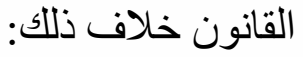

أولا - بالنسبة للكيانات الإرهابية

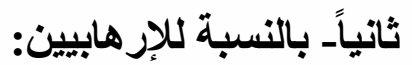

(146) د أكمل يوسف السعيد يوسف، قوائم الكيانات الارهابية والار هابيين في ضوء الثربة الثرعية الدستورية والجنائية، الطبعة الاولى، مركز

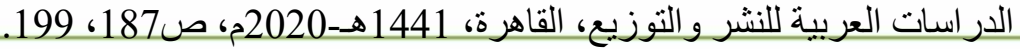

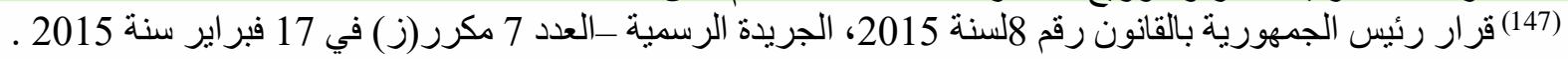




\section{1- الإدر اج على قو ائم المنع من السفر وترقب الوصول، أو منع الأجنبي من دخول البلاد 2-سحب جواز السفر أو إلغاؤه، أو منع إصدار جواز سفر جديد}

وتلتزم جميع سلطات وجهات و هيئات و أجهزة الدولة، كل في حدود اختصاصه، بأعمال و إنفاذ الآثار المشار إليها، وبإبلاغ الجهات المعنية في الداخل و الخارج لأعمال آثار الإدر اج على أي من القائمتين). وجاء في المادة الثانية من ذات القانون بأن (... كما تعد النيابة العامة قائمة أخرى تسمى (قائمة الإرهابيين)، تدرج عليها أسماء الإرهابيين، إذا قررت الدائرة

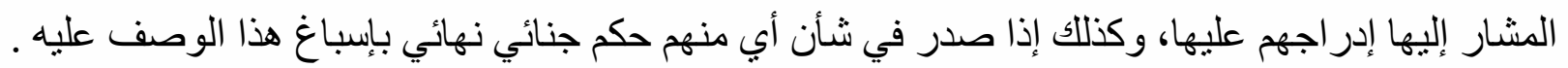
وتسرى على هذه القائمة ذات الأحكام المقررة في شأن قائمة الكيانات الإرهابية ). و الإدر اج في قو ائم الإرهاب وفقاً لما قرره هذا القانون هو قرار قضائي بوضع اسم كيان أو شخص يتصل بنشاط إر هابي في قوائم، ويؤدي صدور هذا القرار ونشره إلى حرمانه من حقوق معينة أو تقييد حريته على نحو معين، وقد

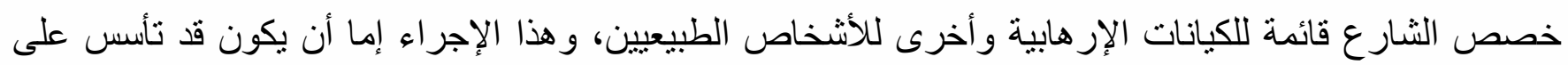
صدور حكم نهائي بالإدانة بجريمة إر هابية، و إما يكون الإدر اج بدون صدور حكم. وفي الحالتين يجب أن يكون الإدر اج في القو ائم بقرار من الدائرة المختصة، ويترتب علي صدور الإدر اج ونشره العديد من الآثار، وتستمر هذه الآثار طوال

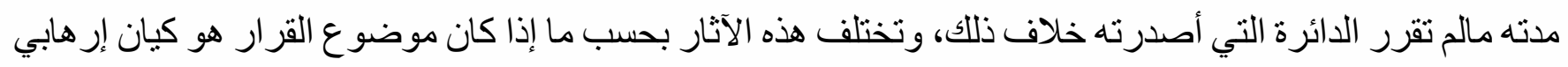
أم شخص طبيعي، وما يههنا هنا الآثار المترنبة على الإدر اج بالنسبة للنخص الطبيعي.

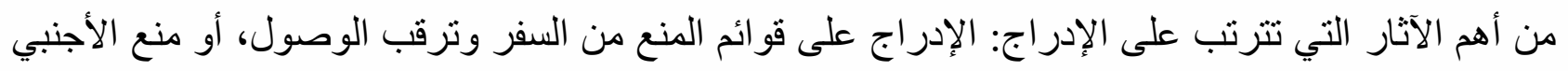

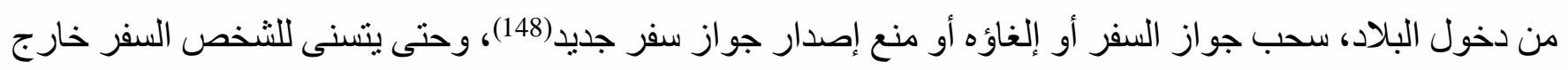

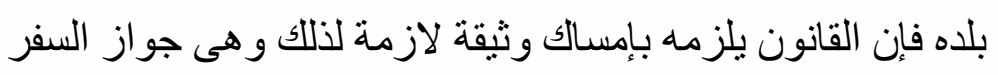

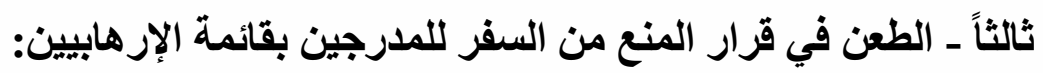
يعد المنع من السفر أحد الآثار التي تترتب بقوة القانون على الإدراج بقائمة الإرهابيين، ونشر هذا القرار في الوقائع المصرية مالم تقر الدائرة المنصوص عليها في المادة الثالثة من هذا القانون خلاف ذللك، وبالتالي فإن التظلم من التهن المنع من السفر لن يكون بمعزل عن التظلم بالإدر اج في قائمة الإر هابيين فهو يدور مع قر ار الإدر اج في قائمة الإرهابيين

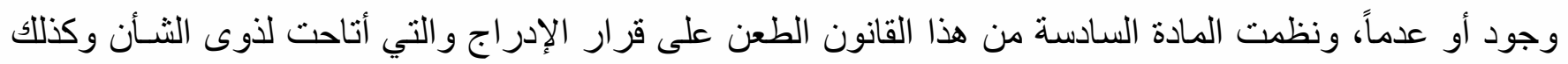




\section{محمد السعبد القز عة}

للنيابة العامة الطعن في القرار الصادر بالإدر اج في أي من القائمنين خلال (ستين يوماً) من تاريخ نشر القرار، وذلك أمام الدائرة الجنائية بمحكمة النقض التي تحددها الجمعية العمومية للمحكمة سنوياً، وذلك وفقاً للإجر اءات المعتادة للطعن.

وفي تصوري أن الآثار التي رتبها المشرع على قرار الإدر اج في قائمة الإرهابيين ونشره هي غاية في الجسامة وتخالف الدستور الذي أكد على أن الحرية الثخصية مصونة، وعلى رأس تلك الآثار المنع من السفر، وتأكيداً لذلك قرر إمكانية سحب جواز السفر أو إلغاؤه أو منع إصدار جواز سفر جديد، فالمشر ع لم يوجب بضرورة وجود سند لهذا الإدر اج في تللك القائمة، و إنما اكتفي بطلب الإدر اج وصدوره دون أن تكون هناك ضرورة تستوجب ذلك إنك على عكس ما تطلبه المشرع من إجر اءات للمنع من السفر في قانون الكسب غير المشروع وقانون مكافحة الإر هاب وقانون مكافحة

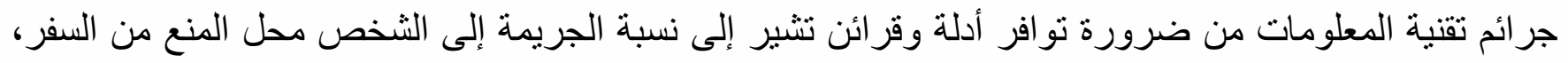
وكذلك وجود تحقيقات من جهة مختصة كقاضي التحقيق أو النيابة العامة، ووجود ضرورة تبرر اتخاذ مثل هذا القرار. كل تللك الضوابط أغفلها المشرع الأمر الذي يستدعي تعديل تشريعي لتعديل النص بما يتو افق مع الدستور و القانون . 


\section{الفرع الثاني}

\section{المنع من السفر في قانون مكافحة الإرهاب}

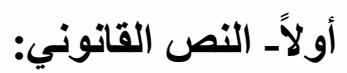

تسري أحكام المو اد 208 مكرر(أ) و 208مكرر(ب) و 208مكرر (ج) و208مكرر (د) من قانون الإجراءات الجنائية في الأحوال التي يظهر فيها من الاستدلال أو التحقيق دلائل كافية على الاتهام بجريمة إرهابية، وللسلطات

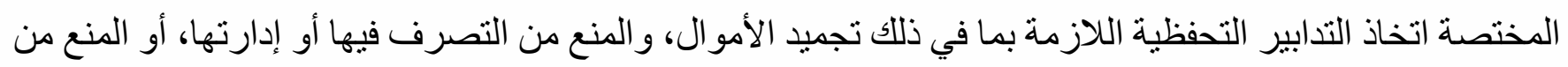
السفر، على أن تلنزم بالأحكام و الإجراءات المنصوص عليها في المواد المذكورة بالفقرة الأولى من هذه المادة ).

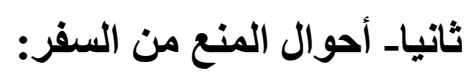
جاء في الباب الثاني المتعلق بالأحكام الإجرائية من قانون مكافحة الإرهاب محدداً لحالات المنع من السفر في

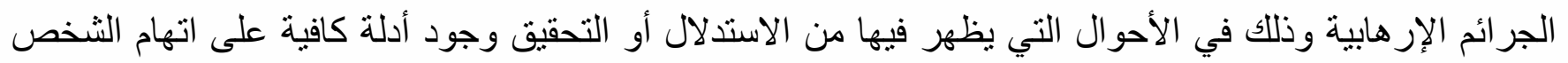
بارتكاب أحد الجر ائم الإر هابية أو الثروع فيها، ويخضع تقدير مدى جدية أدلة الاتهام من عدم جديتها للنيابة العامة أو لسلطة التحقيق المختصة، غير أنه أوجب أن يكون اتخاذ إجراء المنع من السفر باعتباره من ضمن التدابير التحفظية التهاية بحسب ما نص عليه المشرع في المو اد 208مكرر(أ) وما بعدها من قانون الإجر اءات الجنائية، ويعنى ذللك أنه يجب أن يكون المنع من السفر بمناسبة التحقيق في جريمة من جرائم الإرهاب، وأن تتو افر هناك ضرورة بشأن بهان اتخاذ هذا الإجر اء، ويجب الحصول على إذن من المحكمة المختصة، وفي حالة الضرورة والاستعجال يجوز أن يأمر النائب العام بالمنع من السفر على أن يعرض أمر المنع على المحكمة الجنائية المختصة خلال سبعة أيام على الأكثر من تاريخ

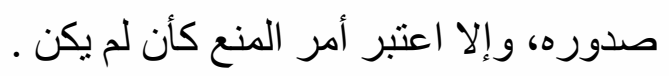
ويحمد للمشرع المصري تقييد اتخاذ التدابير التحفظية المنصوص عليها في المادة السابعة والأربعين من ذات القانون ومن ضمنها المنع من السفر بالإجراءات المنصوص عليها بالمادة 208 مكرر (أ) وما بعدها من قانون

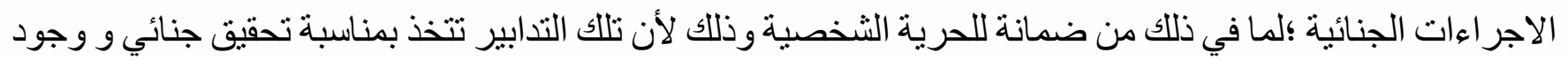
أدلة كافية على جدية الاتهام، وقد خلا القانون رقم 8 لسنة2015 بشأن تنظيم قو ائم الكيانات الإرهابية و الإر هابيين منها فهو لم يوجب أن تكون تللك التدابير التحفظية بمناسبة تحقيق، ولم بربط صدور قرار بالإدر اج على قوائم الإرهاب بصدور حكم جنائي في الموضوع بل قرر أن يكون الإدر اج لمدة ثلاث سنو ات يجوز تجديدها لمرة واحدة، و هذا الأمر يجعل الإدر اج غير مقيد بأي قيد.

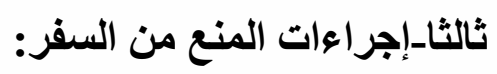




\section{محمد السعبد القز عة}

يصدر قرار المنع من السفر في حالة وجود دلائل كافية من الاستدلال والتحقيق على ارتكاب جريمة إرهابية أو الثروع فيها، ويكون ذللك بعرض النيابة العامة أمر المنع من السفر على المحكمة الجنائية المختصة، وللنائب العام عند

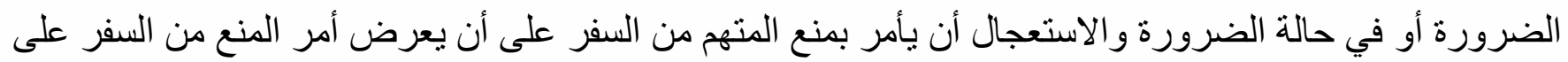

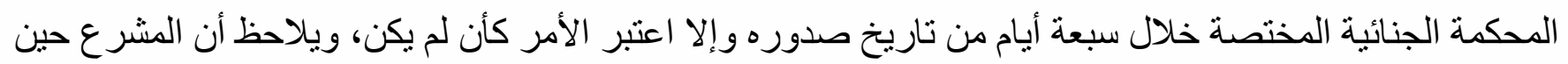
رتب جزاء (السقوط) جراء عدم عرض الإجراء الوقتي على المحكمة المختصة في الموعد المقرر إنما قصد بذللك تحقيق الموازنة بين حالة الضرورة والاستعجال وبين ضمانات الممنوع من السفر ، وتصدر المحكمة الجنائية المختصة حكمها في التدابير التحفظية ـ ومن بينها منعه من السفر - بعد سماع أقو ال ذوى الثأن خلال لمدة لا تجاوز خمسة عشر من

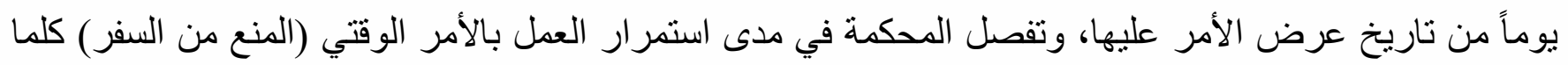
رأت وجهاً لتأجيل نظر الطلب، ويجب أن يشمل الحكم على الأسباب التي بني عليها. (المادة 208 مكرر(أ) إجر اءات جنائية).

على أنه يلاحظ إذا عرض طلب الأمر باتخاذ الإجراءات التحفظية على المحكمة المختصة فقضت بتأييد قرر النائب بمنع المتهم من السفر، فإنه لا يجوز أن يشترك أي من أعضائها في نظر الموضوع؛ ذللك أن تأييد القرار يعني أن المحكمة سبق وأن أبدت رأياً في الدعوى(149) ؛ لذلك قضت محكمة النقض بأنه (إذا كانت المحكمة قد أوردت في مدونات حكمها تأييداً للقرار بالمنع أن الثابت من تحقيقات النيابة العامة وجود أدلة كافية لديها تفيد طبقاً لتقدير اتها جدية الاتهام المسند إلى المتهم، ومن ثم فإن المحكمة تقضي بمنع المتهم وزوجته وأولاده القصر ومن يمثلهم قانوناً من التصرف في أمو الهم على النحو الوارد في منطوق الحكم)(150)، و لاشك أن ما بسري على المنع من التصرف في الأمو ال هو ما يسري على المنع من السفر فالنتيجة واحدة وهى تأثر المحكمة في تكوين عقيدتها من ناحية ثبوت التهمة بحق المتهم، وفي ذلك قضي بأن (أساس وجوب الامتناع أن صدور الحكم المطعون فيه من القاضي يجعل رأيا في الدعوى يتعارض مع ما يشترط في القاضي من خلو الذهن عن موضو عها ليستطيع أن يزن حجج الخصوم في حيدة

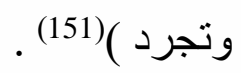


كما قضت محكمة النقض بأن (وكان الثابت مما سلف بيانه أن رئيس الهيئة التي حكمت بمنع الطاعن من التصرف في أمو اله قد أبدى رأياً معيناً ثابتاً في الدعوى هو اقتناعه وفقاً لتقدير النيابة العامة بقيام الأدلة على جدية الاتهام، هو بذاته رئيس الهيئة التي أصدرت الحكم المطعون فيه يكون باطلاً لصدوره من هيئة فقد رئيسها صلاحيتها)(152). 


\section{رابعاً ـ التظلم من أمر المنع من السفر:}

يحق لكل من صدر بحقه أمر ا بالَّنع من السفر نظر اً لاتهامه بارتكاب جريمة إرهابية أو الثروع فيها، أن يتظلم

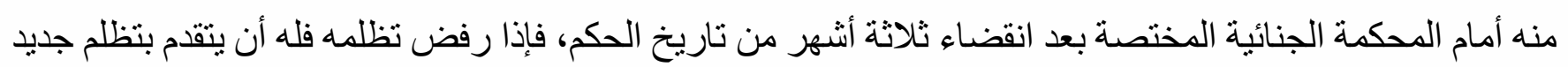
كلما انقضت ثلاثة أثهر من تاريخ الحكم برفض التظلم ويحصل التظلم بتقرير في قلم كتاب المحكمة الجنائية المختصة، و على رئيس المحكمة أن يحدد جلسة لنظر التظلم يعلن بها المتظلم وكل ذوي الثأن، و على المحكمة أن تفصل في التظلم خلال مدة لا تجاوز خمسة عشر يوماً من تاريخ التقرير به، وللمحكمة المختصة أثناء نظر الدعوى ـ من تلقاء نفسها أو بناء على طلب النيابة العامة أو ذوي الثـأن -

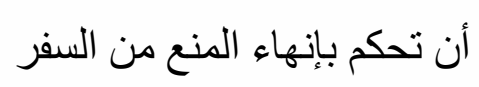
ويجب أن يبين الأمر الصادر بالتصرف في الدعوى الجنائية أو الحكم الصادر فيها ما يتبع في شأن التدابير

التحفظية (مادة 208مكرر ب إجر اءات جنائية ).

\section{المطلب الثالث}

\section{المنع من السفر في قانون مكافحة جرائم تقنية المعلومات}

جاء في الباب الثاني من قانون مكافحة جر ائم تقنية المعلومات رقم 175 لسنة 2018 وتحت عنوان الأحكام و القواعد الإجر ائية، وذللك في المادة التاسعة حالات منع المتهمين من السفر، والإجر اءات المنظمة لكيفية هذا المنع وجهة إصداره، وطرق التظلم منه و إنهائه، ومدة سريانه، ويمكن القول أن نص المادة التاسعة من هذا القانون و المنظمة والإنة

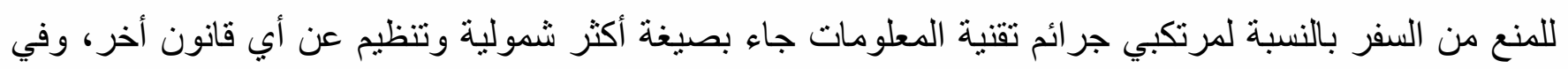

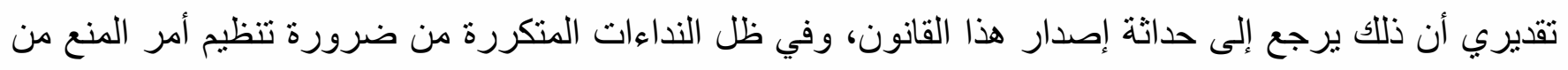
السفر باعتباره من أخطر الأمور المتعلقة بالحرية الثخصية بما ينو افق مع المنصوص عليه دستورياً.

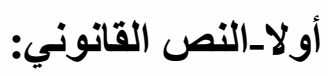

قررت المادة التاسعة من قانون مكافحة جر ائم تقنية المعلومات بأن (يجوز للنائب العام أو من يفوضه من المحامين العموم الأول بنيابات الاستئناف، ولجهات التحقيق المختصة، عند الضرورة أو عند وجود أدلة كافية على جدية الاتهام

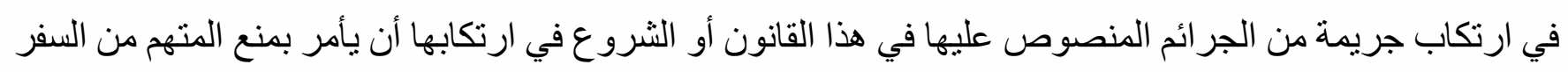

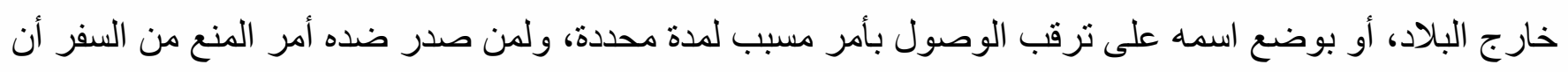

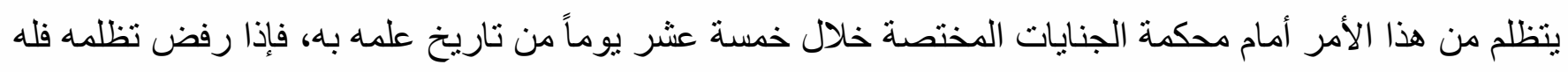

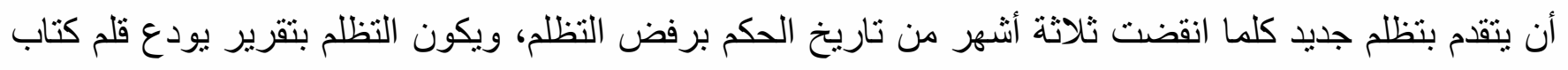

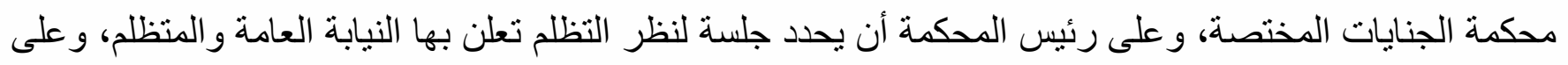




\section{محمد السعبد القز عة}

المحكمة أن تفصل في التظلم خلال مدة لا تتجاوز خمسة عشر يوماً من تاريخ التقرير به بحكم مسبب بعد سماع أقوال

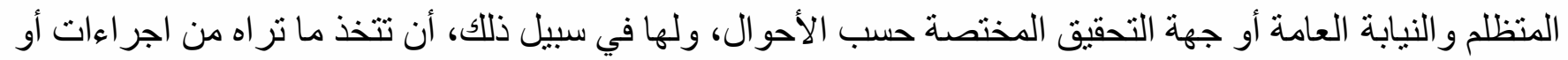
تحقيقات نرى لزومها في هذا الثأن، ويجوز للنيابة العامة وجهات التحقيق المختصة في كل وقت العدول عن الأمر

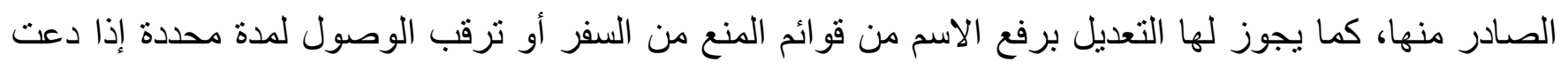

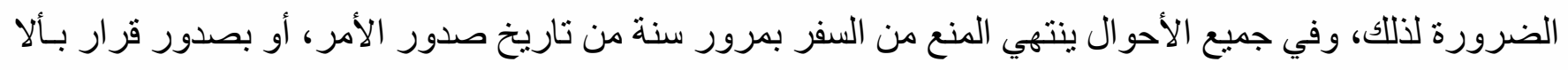

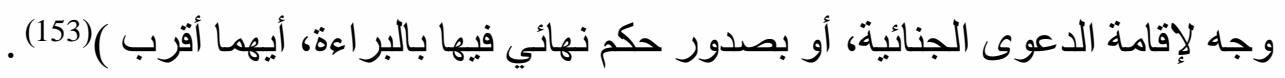

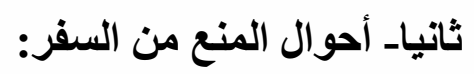

حددت المادة التاسعة من هذا القانون حالات المنع من السفر في جرائم المعلوماتية والمتمثلة في وجود حالة الضرورة التي تتطلب معها منع الثخص من السفر، وكذلك وجود أدلة كافية على اتهامه بارتكاب إحدى الجرائم المعلو ماتية أو الثروع في ارتكابها، ويخضع مدى تو افر الأدلة الكافية على صحة الاتهام الموجه للمتهم للسلطة التقديرية للنائب العام أو من يفوضه من المحامين العموم الأول بنيابات الاستئناف، وفي ضوء المعلومات المتو افرة لدى النيابة العامة على صحة الاتهامات الموجهة للمتهم(154) ثالثا_جهة إصدار المنع من السفر: يصدر الأمر بمنع المتهم بارتكاب جر ائم معلوماتية من السفر أو الثروع في ارتكابها من النائب العام أو من يقوم بتفويضه من السادة المحامين العموم الأول بنيابات الاستئناف، على أن يكون الأمر مسبب ولمدة محددة . رابعا_التظلم من قرار المنع من السفر وإجراءاته: أوضح القانون أن لمن صدر ضده أمر بالمنع من السفر التظلم من هذا المنع أمام محكمة الجنايات المختصة وذلك في مو عد أقصاه خمسة عشر يوماً من تاريخ علمه به، و إذا رفض تظلمه يجوز أن يتقدم بتظلم جديد وذلك بعد مرور ثلاثة أنشهر من تاريخ الحكم برفض التظلم . ويحصل التظلم من خلال تقرير يودع قلم كتاب محكمة الجنايات المختصة، و على المحكمة أن تفصل في التظلم خلال مدة لا تجاوز خمسة عشر يوماً من تاريخ التقرير به، ويكون ذلك بحكم مسبب وبعد سماع أقو ال المتظلم والنيابة

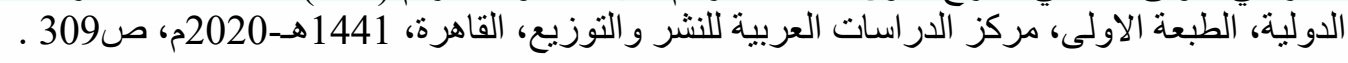


العامة أو جهة التحقيق المختصة حسب الأحوال، ويكون لمحكمة الجنايات المختصة أثناء نظر التظلم على قرار المنع من السفر أن تتخذ ما تراه من إجر اءات أو تحقيقات ترى لزومها في هذا الثأن. 
خامسا_العدول عن قرار المنع من السفر:

بينت المادة التاسعة من القانون أحو ال العدول عن قرار المنع من السفر بأن أجازت للنيابة العامة وجهات التحقيق المختصة في كل وقت العدول عن الأمر الصادر منها بالمنع من السفر، كما يجوز لها التعديل فيه برفع الاسم من قو ائم

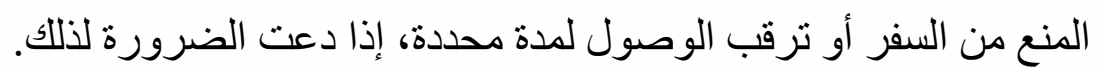
و أثشارت ذات المادة إلى أن انتهاء المنع من السفر بمضي سنة من تاريخ صدور الأمر ، أو صدور أمر بألا وجه إنه

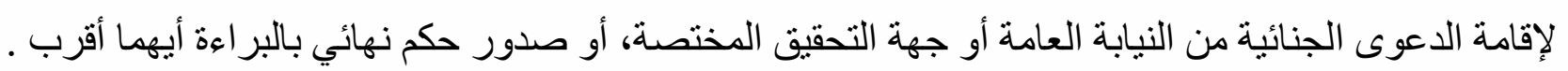




\section{المبحث الرابع \\ الأحكام الإجرائية للمنع من السفر في المواد الجنائية}

تمهيل وتقسيم:

تتمثل الأحكام الإجر ائية للمنع من السفر في مجموعة القو اعد الو اجبة الاتباع قانوناً من قبل السلطات والأجهزة

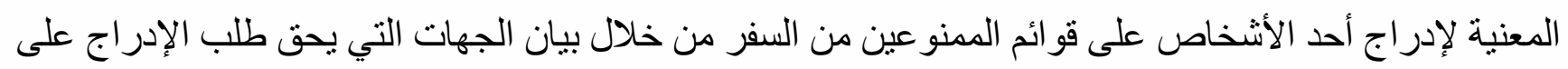
تللك القو ائم، و التي تنقسم إلى جهات قضائية و أخرى إدارية، وتنظيم إدر اج الأشخاص على قو ائم الممنو عين، و التظلم من هذا الإدر اج، ومدته وفيما يلى بيان ذللك من خلال: • المطلب الأول: الجهات المنوط بها المنع من السفر.

• المطلب الثاني: تنظيم إدراج الأشخاص الممنوعين من السفر والرفع منها . • المطلب الثالث: التظلم من الإدراج على قوائم الممنوعين من السفر ـ المطلب الأول

\section{الجهات المختصة بإصدار المنع من السفر}

تضمن قرار الداخلية رقم 54 لسنة 2013 بشأن تنظيم قو اعد الإدر اج على قو ائم الممنوعين من السفر عدة جهات أناط بها القرار الوزاري السالف إمكانية المنع من السفر، وتتنوع تللك الجهات طالبة الإدر اج على قو ائم الممنو عين بين جهات قضائية و أخرى تنفيذية وفيما يلى بيان ذلك من خلال:

\section{القرع الأول}

\section{الإدراج على قوائم الممنوعين من السفر الصادر من جهات قضائية}

الأصل هو حرية السفر للأفراد، تلك القاعدة التي كفلتها المواثيق الدولية والتشريعات الوطنية، وعلى رأسها الدستور المصري النافذ الصادر في 2014، ووفقاً لما وارد في القرار الوزاري 54 لسنة 2013 المنظم لقواعد الممنوعين من السفر يتضح أن طلبات الإدراج للمنع من السفر إما أن تصدر من جهات قضائية كالتي تصدر من (المحاكم -النائب العام - قاضى التحقيق ـمساعد وزير العدل للكسب غير المشروع ـالمدعى العام العسكري) وإما أن تصدر من جهات تنفيذية مثل التي تصدر من (رئيس المخابرات العامة ــرئيس هيئة الرقابة الإدارية ـمدير إدارة المخابرات الحربية ومدير إدارة الثؤن الثخصية والخدمة الاجتماعية للقوات المسلحة ـمساعد وزير الداخلية لقطاع الأمن الوطني -مساعد وزير الداخلية لقطاع مصلحة الأمن العام) وقد اشترط القرار أن يكون طلب الإدر اج على قو ائم 
الممنوعين من السفر في غير حالات طلب المحاكم صادر ا من رئاسة الجهات المشار إليها في هذا القرار دون فرو عها

\section{أولاًَ- المحاكم وأوامرها واجبة النفاذ:}

حدد المشرع حالات النفاذ للأحكام إما بصيرورة الحكم نهائياً أو بأحكام صادرة في الثق العاجل، وحددت المادة 280 من قانون المر افعات المدنية والتجارية حالات النفاذ المعجل القانوني بقوة القانون، مثل الأحكام الصادرة بالنفقة،

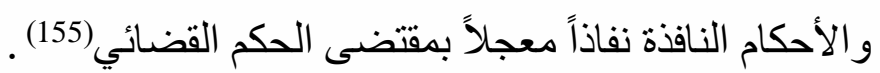

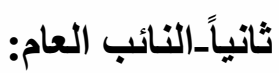

يعد النائب العام هو رأس النيابة العامة وهو الأمين على الدعوى العمومية، ومنح قرار وزير الداخلية رقم 54

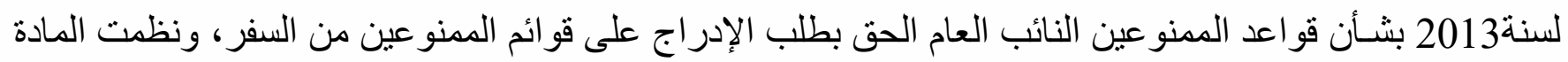

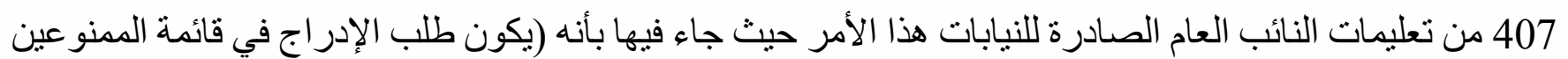

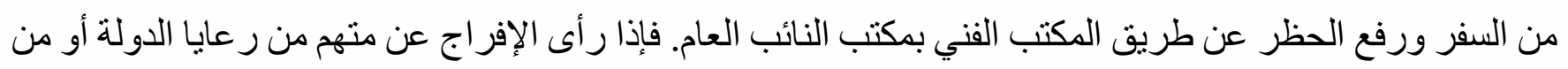

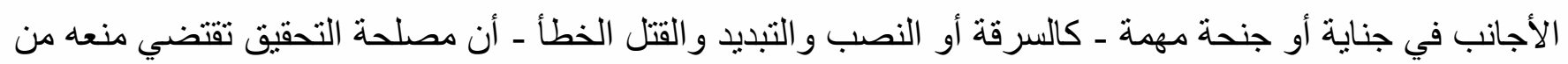
السفر إلى الخارج فعلى المحقق إرسال مذكرة بصفة عاجلة إلى رئيس النيابة الكلية يوضح فيها الأسباب التي تدعو إلى

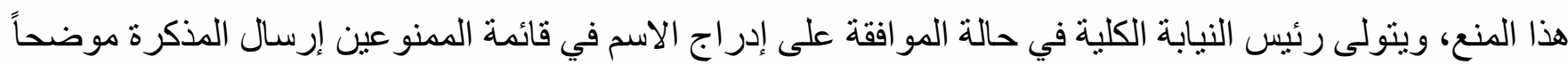
عليها الاعتبار ات المهمة من وجهة نظره إلى المكتب الفني لفحص الطلب، و إخطار إدارة الجوازات و الجنسية.....)(156).

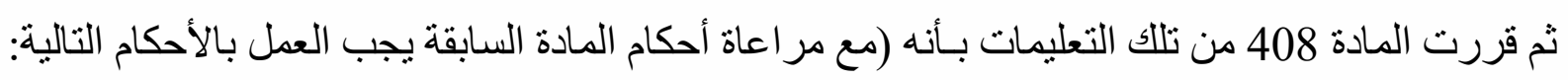
أو لا: ير اعى عند استجواب المتهم يذكر في محضر التحقيق اسمه ثلاثياً (اسم المتهم - اسم الاب - اسم الجد ) وتاريخ الميلاد باليوم و الثهر و السنة، ومحل الميلاد، ومحل الإقامة و المهنة و الجنسية، والاطلاع على بطاقته أو جواز لهاز سفره؛ حتى يمكن الاستعانة بهذه البيانات في تحرير نماذج طلبات الإدر اج في قو ائم الممنو عين من السفر إلى الخارج

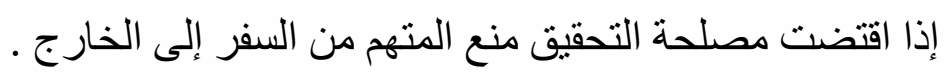
ثانيا: ير اعى عند تحرير نماذج طلبات الإدر اج في قائمة الممنوعين من السفر أن تشتمل من وقع التحقيقات على التى الأسماء الثلاثية للمتهمين (اسم المتهم ـاسم الاب ـاسم الجد-كل في خانة مستقل ) وباقي البيانات المشار إليها في البند 


\section{محمد السعبد القز عة}

ثالثاً: لا يجوز للنيابات مخاطبة مصلحة وثائق السفر والهجرة والجنسية مباثرة في طلب الإدراج في قوائم الممنو عين من السفر وترقب الوصول، وترسل كل مكاتبات النيابات في هذا الخصوص للمكتب الفني للنائب العام، الذي له وحده مخاطبة مصلحة الجو ازات و الهجرة و الجنسية في هذا الثأن ). وينبغي الإشارة إلى أنه جرى العمل بمكتب النائب العام على إصدار تصاريح مؤقتة بالسفر للأشخاص الصادر

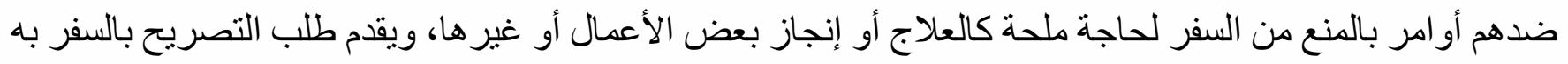
ما يؤيده إلى مكتب النائب العام، وليست هناك قاعدة أو قو اعد محددة معمول بها في هذا الثأن، و إنما يتم تقدير كل حالة

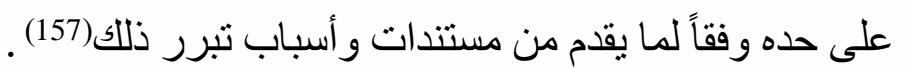
ثنالثاـ قاضي التحقيق: - مانى قاضي التحقيق هو أحد قضاة المحكمة الابتدائية، وله كافة الضمانات المقررة للقضاة، وبالتالي فهو مستقل في عمله عن النيابة العامة والسلطة التنفيذية، ونصت المادة 64 من قانون الإجر اءات الجنائية المعدلة بالقانون 138 لسنة 2014(158)، على أن( إذا رأت النيابة العامة في مو اد الجنايات و الجنح أن تحقيق الدعوى بمعرفة قاضي التحقيق أكثر ملاءمة بالنظر إلى ظروفها الخاصة، جاز لها في أي حالة كانت عليها الدعوى أن تطلب من المحكمة الابتدائية المختصة ندب أحد قضاتها لمباثرة هذا التحقيق، ويكون الندب بقرار من الجمعية العامة للمحكمة أو من تفوضه في ذلك في بداية كل عام قضائي، وفي هذه الحالة يكون القاضي المندوب هو المختص دون غيره بإجر اء التحقيق من وقت مبانشرنه

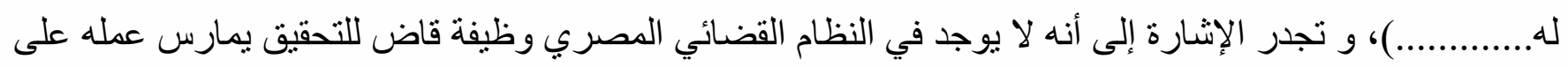
نحو مستمر ودائم، و إنما يندب قاضي التحقيق على وجه عارض ومؤقت للتحقيق في دعوى بعينها، فإذا انتهى التحقيق زال اختصاصه و عاد إلى عمله القضائي الأصلي(159). وقاضي التحقيق أحد الجهات التي تضمنتها المادة الأولى من قرار وزير الداخلية رقم 54 لسنة 2013 بشأن قو ائم الممنو عين من السفر والذين يحق لهم طلب الإدر اج على تللك القو ائم، ويكون طلبه بمنع متهم من السفر بمناسبة تحقيق ندب له، و يقدر وحده ملاءمة منع المتهم من السفر من عدمه وفقاً لما تقتضيه ضرورة التحقيق، لذلك قضي بأن (لما كان تدخل قاضي التحقيق بإصدار قرار المنع من السفر بمناسبة تحقيق جار هو قرار صـادر استنادا إلى الاختصاص المقرر لقاضي التحقيق بحسبانه أميناً على الدعوى العمومية وفي إطار ممارسة اختصاصه القضائي)(160). 


\section{محمد السعبد الفز عهة}

رابعاًَ مساعد العدل للكسب غير المشروع:

جاء القانون رقم 62 لسنة 1975بشأن الكسب غير المشروع خالياً من أي تنظيم لمساءلة المنع من السفر، لذللك قضت المحكمة الإدارية العليا بأن (نصوص القانون المذكور خلت من ثمة نص يخول هيئات الفحص والتحقيق المذكورة فيه بالاختصاص بإصدار أمر بمنع المنهم في جريمة كسب غير مشروع من السفر للخارج)(161)، غير أنه في الآونة الاخيرة صدر قرار رئيس الجمهورية بالقانون 97 لسنة 2015 بتعديل بعض أحكام القانون 62 لسنة 1975 في شأن الكسب غير المشروع؛ ليتضمن تنظيم إجرائي جديد لقرارات المنع من السفر، حيث قررت المادة (13) مكرر بأنه يجوز للهيئة المختصة بالفحص و التحقيق عند الضرورة أو في حالة وجود أدلة كافية على جدية الاتهام في جناية الكسب غير المشروع وكذا في جريمة إخفاء الأمو ال الناتجة عنها أن تطلب من النيابة العامة منع المتهم من السفر، غير أنه يلزم لصدور أمر المنع من السفر في قضايا الكسب غير المشروع أن يكون الصادر بحقه أمر المنع من الفئات الخاضعة لأحكام هذا القانون، عدا الفئات المشار إليها في نص المادة العاثرة من هذا القانون (رئيس الجمهورية ــونوابه ــرئيس الوزر اء ونو ابه_الوزراء ونو ابهم ـأعضاء مجلس الثتب )، وكذا لابد من وجود حالة ضرورة أو دلائل كافية على جدية الاتهام تقدر ها هيئة الفحص و التحقيق.

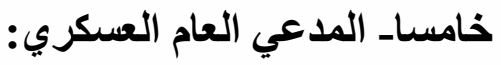
يعتبر المدعي العام العسكري هو رأس الادعاء العسكري، وهو بذات مرتبة النائب العام بالنسبة إلى المدنيين، فالإجر اءات التي تتخذها سلطة التحقيق العسكرية طبقاً لقانون الأحكام العسكرية هي إجر اءات جنائية ومن ثم جاء

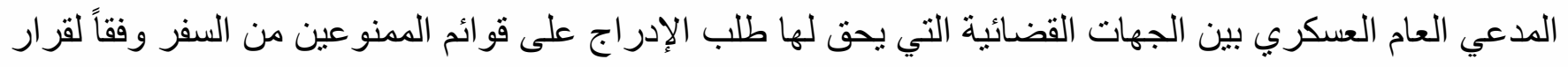
وزير الداخلية رقم 54 لسنة 2013

وقررت المادة (5) من القانون رقم (25) لسنة 1966 بثـأن الأحكام العسكرية(162) بأن (يتولى النيابة العسكرية (مدع عام ) مجاز في الحقوق و لا تقل رتبته عن مقدم يعاونه عدد من أعضاء النيابة لا تقل رتبتهم عن ملازم أول)، وجاء نص المادة (28) من ذات القانون ليؤكد على أن (تمارس النيابة العسكرية بالإضافة إلى الاختصاصات المخولة

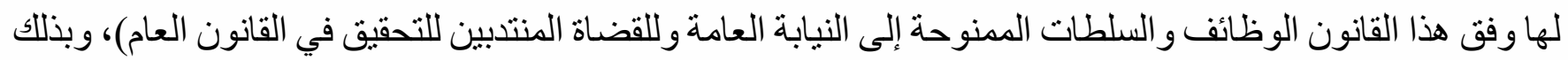
فإن المدعي العام العسكري يمارس سلطته في طلب الإدراج على قو ائم الممنوعين من السفر، استتادا إلى تللك المادة التي خولت النيابة العسكرية و على رأسها المدعي العام العسكري ذات السلطات الممنوحة للنيابة العامة. الفرع الثاني 
المنع من السفر في المواد الجنائية

\section{محمد السعبد القز عة}

\section{المنع من السفر الصادر من جهات تنفيذية}

تضمن قرار وزير الداخلية 54 لسنة 2013 بشأن قو ائم الممنو عين من السفر جهات تنفيذية يحق لها طلب الإدر اج

على قو ائم الممنوعين من السفر، شريطة أن يكون طلب الإدراج صادر من من رئاسة تللك الجهات وهي (رئيس المخابر ات العامة ــرئيس هيئة الرقابة الإدارية ـمدير إدارة المخابر ات الحربية ومدير إدارة الثؤن الثخصية و الخدمة

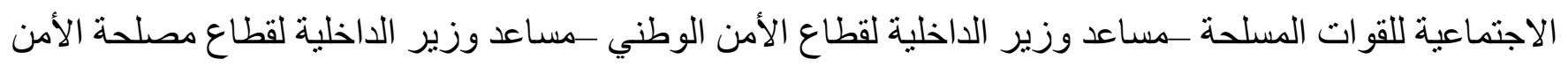
العام) وقد اشترط القرار أن يكون طلب الإدراج على قو ائم الممنو عين من السفر في غير حالات طلب المحاكم صادر من رئاسة الجهات المشار إليها في هذا القرار دون فروعها. ووفقاً لما سبق يتضح أن القرار الوزاري المعني أتاح طلب الإدراج على قوائم الممنوعين من السفر بناء على دلى طلب جهات أمنية و عسكرية(163) أولاَسلطة وزير الاخلية: كانت المادتين (8،11) من القانون رقم 97 لسنة 1959 بشأن جوازات السفر تخولان وزير الداخلية الحق في رفض منح جواز ات أو تجديد ها أو سحبها بعد إعطائها، ومن خلال تلك الإجر اءات يستطيع وزير الداخلية منع المواطنين من السفر باعتبار جواز السفر هو الوثيقة التي تحرر ها السلطة الإدارية بعد أن تتحقى من شخصية صاحبها، وتسمح له بمقتضاها بمغادرة البلاد(164)،و على الرغم من تشابه وظيفة جو از السفر مع بطاقة تحقيق الثخصية في أن كليهما يصلح لإثبات الثخصية على التراب الوطني إلا أن الإدارة تتمتع بسلطة تقديرية كبيرة في منح جواز السفر أو رفض منحه أو سحبه بعد إعطائه(165)، وبالتالي يمكن لوزير الداخلية المنع من السفر في حالة وجود أسباب جدية تبرر هذا المنع، كما يكون له ولذات الاعتبار ات سحب أو رفض منح جواز السفر (166)، غير أن حرية التنقل تنخرط في مصاف الحريات العامة، وأن تقييدها دون مقتضى مشروع إنما يقوض الحرية الثخصية من بعض خصائصها، ويقوض صحيح بنيانها، وقد عهد الدستور إلى السلطة التشريعية دون غيرها تقدير هذا المقتضى، ولما كان هذا التنظيم يتعين أن تتو لاه السلطة التشريعية فلا يجوز لها أن تتحلل من اختصاصها وتحيل الأمر برمته إلى السلطة التنفيذية دون أن تقيد ها بضو ابط عامة

و أسس رئيسة تنظم الحق من أساسه كان ذلك تخلياً عن اختصاصه الأصيل ساقطاً في هذه المخالفة الدستورية(167).

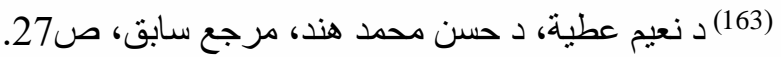

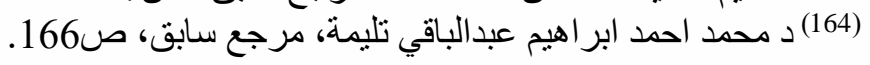

(165) J.Morange, libertés publiques,1985,p 122; Claude- Albert Colliard, Libertés publiques, 6e éd, Paris, Dalloz, 1975,p. 323. 


\section{محمد السعبد القز عه}

لذللك أصدرت المحكمة الدستورية العليا بتاريخ 2000/11/4 حكما بعدم دستورية نص المادتين (8،8، من قانون جوازات السفر، الأمر الذى ترتب عليه انهيار السند التشريعي المرنكز عليه وزير الداخلية في إصدار المنع من السفر، وبالتالي عدم شرعية الأمر الصادر بالمنع من السفر من وزير الداخلية أو من الجهات الأمنية التابعة له كمساعد وزير الداخلية لقطاع الأمن الوطني، مساعد وزير الداخلية لقطاع مصلحة الأمن العام، لافتقادهما للسند القانوني، إلا أن لاعتبار ات الأمن القومي ولحماية مصالح البلاد قد يستدعي الأمر صدور المنع من السفر من تلك الجهات الأمنية ولكن

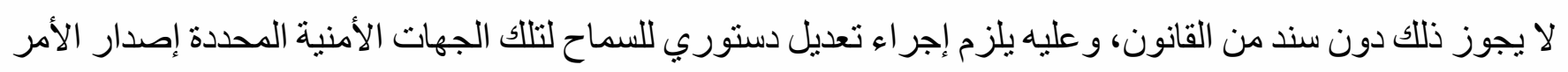
بالمنع من السفر؛ حفاظا على الأمن القومي ومصالح البلاد العليات(168) ثانيا: المخابرات العامة:

تختص المخابر ات العامة بالمحافظة على سلامة و أمن الدولة وحفظ كيان نظامها السياسي، وذللك بوضع السياسة

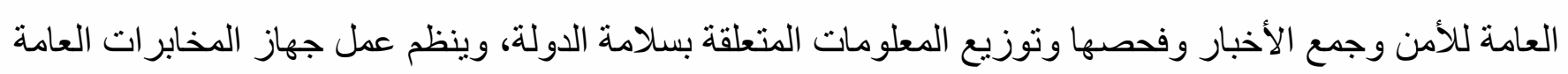

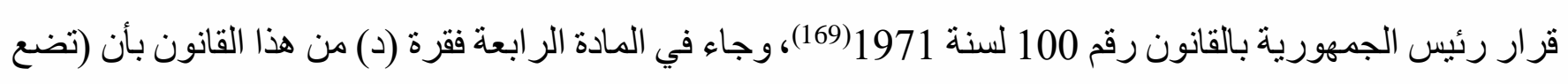

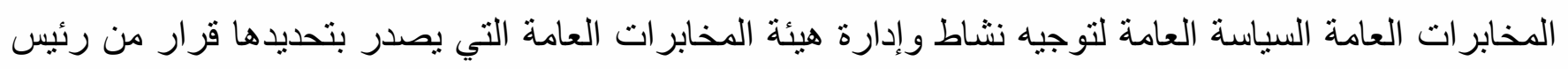

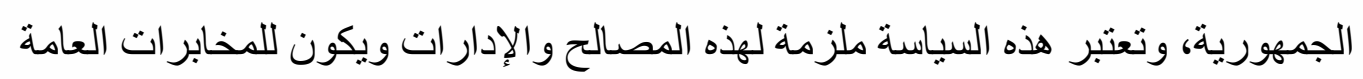

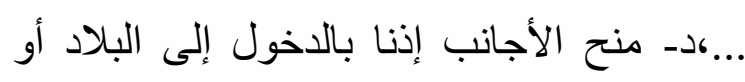
ج. أ....................

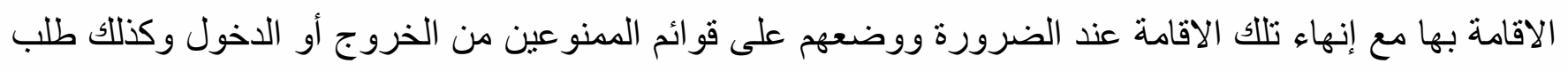

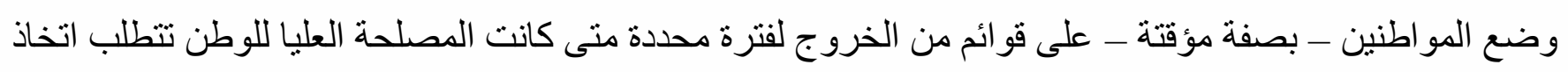
هذا القرار) ويحمد للمشرع المصري معالجة المنع من السفر داخل قانون المخابرات العامة باعتبار ها إحدى الجهات التي

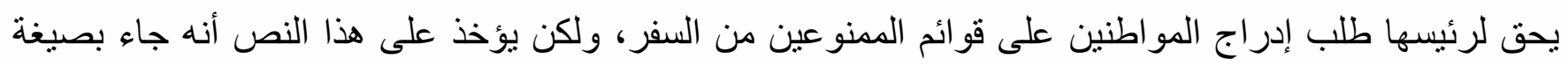
مطاطة من خلال إقراره منع السفر للمو اطنين منى كانت المصلحة العليا للوطن تتطلب ذللك، وفي تللك العبارة مساحة

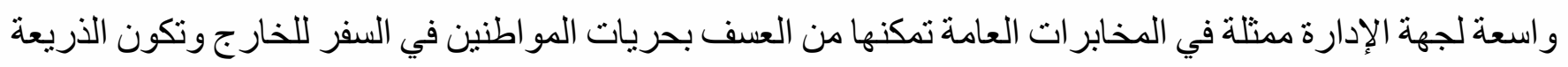

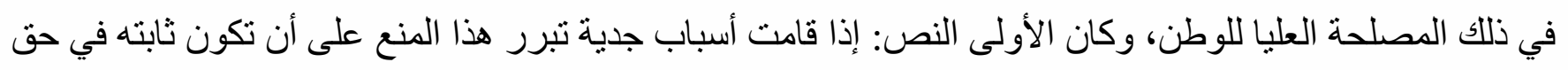
الممنوع من السفر بشكل برجح معه الإضرار بمصالح البلاد.

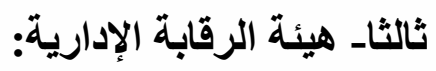


هيئة الرقابة الإدارية هيئة رقابية مستقلة، تتبع رئيس الجمهورية، وتكون لها الثخصية الاعتبارية وتتمتع بالاستقلال الفني و المالي و الإداري، وتهذف الهيئة إلى منع الفساد ومكافحته بكافة صوره، و اتخاذ الإجر اءات و التدابير اللازمة للوقاية منه، لحسن أداء الوظيفة العامة وحفاظا على المال العام وغيره من الأمو ال المملوكة للدولة (المادة

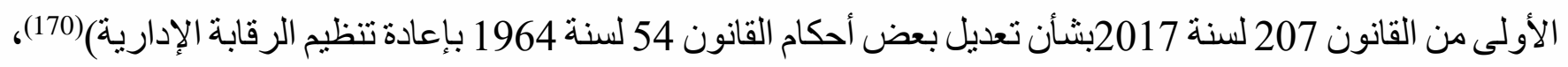
وحددت المادة الثانية من القانون رقم 54 لسنة 1964 اختصاصات هيئة الرقابة الإدارية في بحث وتحري أسباب القصور في العمل والإنتاج، بما في ذلك الكشف عن عيوب النظم الفنية والمالية التي تعرقل السير المنتظم للأجهزة العامة، و اقتر اح تلافيها ومتابعة تنفيذ القو انين، و الكثف عن المخالفات الإدارية و المالية و الجر ائم الجنائية التي تقع من ون

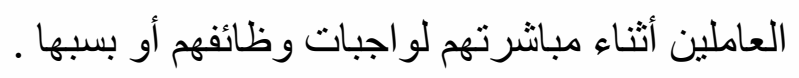
وتجدر الإشارة إلى أن قانون هيئة الرقابة الإدارية 54لسنة 1964 وتعديلاته و التي كان آخر ها القانون 207لسنة

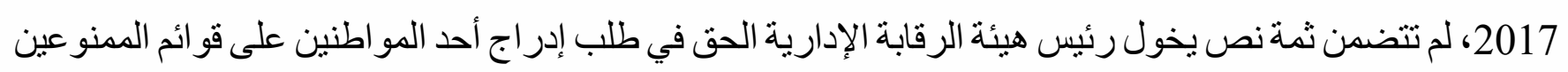

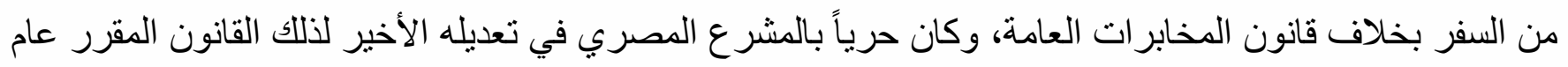

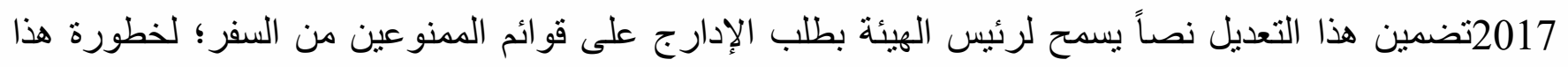

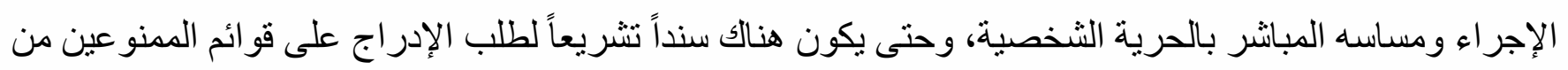
السفر الصادر من رئيس هيئة الرقابة الإدارية.

\section{المطلب الثاني}

\section{تنظيم إدراج الأشخاص الممنوعين من السفر والرفع منها}

$$
\text { أولاًَ تنظيم الإدراج على القوائم: }
$$

حصرت المادة الأولى من قرار وزير الداخلية رقم 54 لسنة 2013 بشأن قو ائم الممنو عين من السفر الجهات التي يحق لها طلب الإدر اج على تللك القو ائم، ونظمت المادة الثالثة من ذات القر ار عملية الإدر اج على القو ائم و الرفع منها، وذللك بتوجيه طلبات الإدر اج من الجهات المحددة بالمادة الأولى إلى مصلحة الجوازات و الهجرة و الجنسية، وتسلم تللك

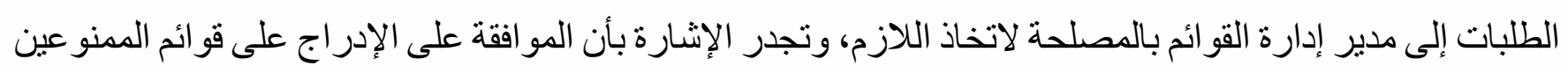

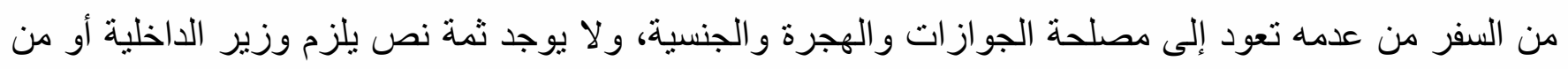

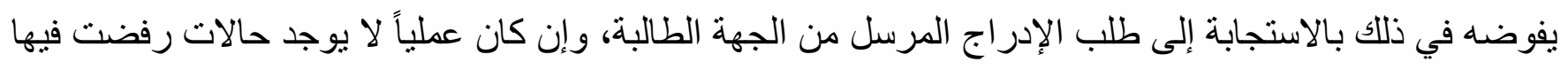

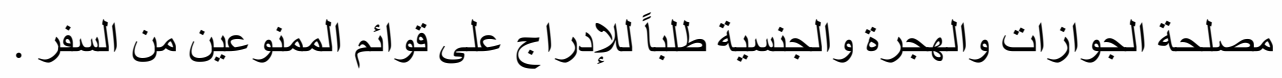


و واشترطت المادة الر ابعة من هذا القرار ضرورة أن تتضمن طلبات القيد بتلك القو ائم عديد من البيانات منها الاسم

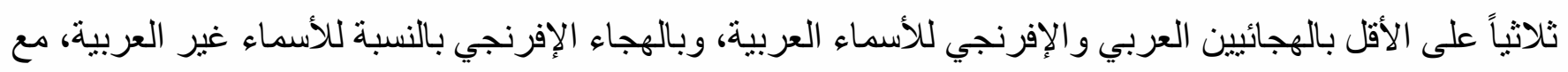
تحديد اسم العائلة بوضع خط أسفلها، الجنسية، جهة وتاريخ الميلاد باليوم والثهر و السنة، المهنة، العلامات المميزة و الصور الفوتوغر افية إن وجدت، ومنحت المادة الخامسة من القرار المشار إليه الصلاحية لقيد الأسماء غير المستوفاة لبعض البيانات المذكورة في المادة السابقة وذلك وفقاً لسلطته التقديرية . ثانياً_رفع الأسماء المدرجة على قوائم الممنوعين من السفر: جاء في المادة السادسة من قرار وزير الداخلية بشأن قوائم الممنوعين من السفر بأنه (تظل الأسماء المستوفية

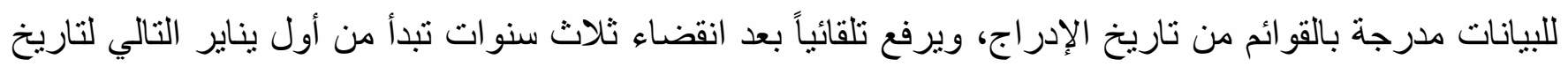

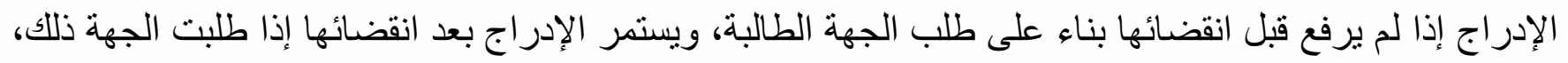
و على الجهات التي لها طلب الإدر اج إعداد سجل خاص لديها بالأسماء التي سبق لها طلب إدر اجها بالقو ائم لمر اجعتها وتصنيفها في المو اعيد المشار إليها في الفقرة السابقة مع إخطار مصلحة وثائق السفر و الهجرة والجنسية بالأسماء التي لهي ترى استمر ار إدر اجها بالقو ائم في مو عد غايته نهاية شهر نوفمبر من كل عام )

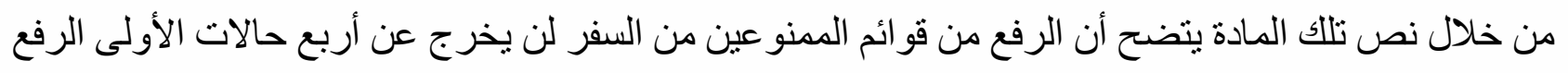

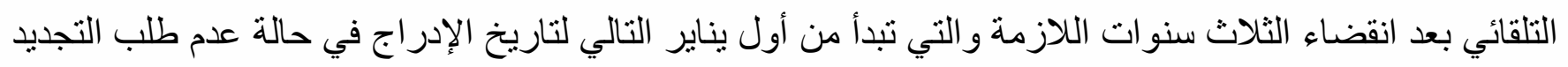

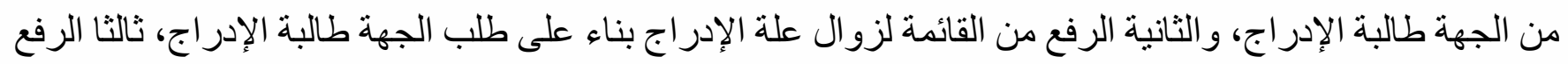
نتيجة النظلم الإداري من قرار الإدر اج، رابعاً أن يكون رفع الإدر اج تنفيذاً للأحكام والأو امر القضائية .

\section{المطلب الثالث}

\section{التظلم من الإدراج على قوائم الممنوعين من السفر}

أولاً- التظلم من طلب الإدراج الصادر من جهة الإدارية:

تتنوع الجهات طالبة الإدر اج على قو ائم الممنو عين من السفر بين جهات قضائية وأخرى تنفيذية، ومن بين الجهات الإدارية التي أناط بها قرار وزير الداخلية 54 لسنة 2013 الحق في طلب الإدراج على قو ائم الممنوعين من السفر ، كرئيس المخابر ات العامة، ورئيس هيئة الرقابة الإدارية، مدير إدارة المخابرات الحربية ومدير إدارة الثئون الثخصية

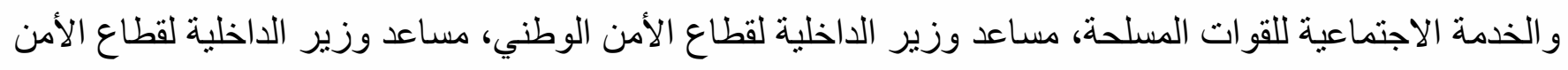
العام، وبالتالي نظمت المادة السابعة من قرار وزير الداخلية 54لسنة 2013 التظلم الإداري من الإدراج على قوائم الممنوعين من السفر، وبينت ذات المادة تشكيل اللجنة التي يتم اللجوء إليها وتتكون من (مساعد وزير الداخلية للأمن الوطني رئيساً- وعضوية كل من مستشار الدولة لإدارة الفتوى لوزارة الداخلية ـمدير مصلحة الجوازات و الهجرة 
و الجنسية ـمندوب عن الجهة طالبة الإدراج ) وينولى سكرتير هذه اللجنة، مدير إدارة القوائم بمصلحة الجوازات

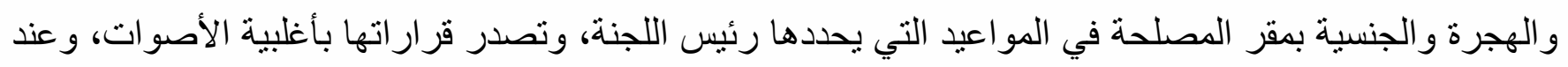
التساوي يرجح الجانب الذي منه الرئيس، ويكون سلوك هذا الطريق للنظلم من الإدر اج على قو ائم الممنو عين إذا كان

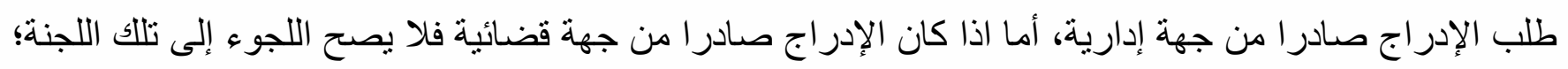

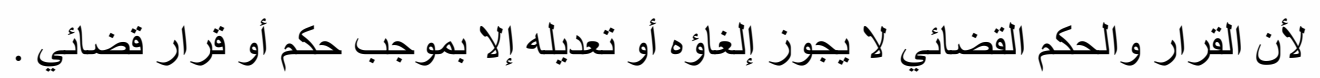

ثانياً_التظلم من طلب الإدراج الصادر من جهة قضائية:

جاء في المادة الأولى من القرار الوزاري 54 لسنة 2013 عديد من الجهات التي يحق لها طلب الإدراج على

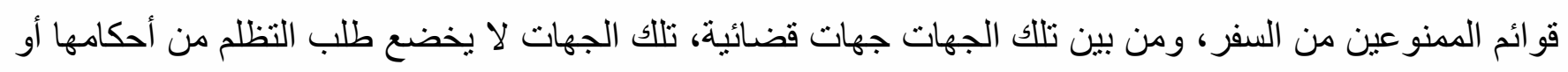
أو امر ها بالإدر اج على قو ائم الممنو عين من السفر لذات الإجر اءات المتابعة في المادة السابعة من ذات القرار و وإنمارسم القانون طريقاً خاص للنظلم يختلف باختلاف القضية المتهم فيها المدرج على قوائم الممنوعين من السفر . أ) التظلم في أمر المنع من السفر في قضايا الكسب غير المشروع:

نظمت المادة الثالثة عشر مكرر من قانون الكسب غير المشروع كيفية التظلم من أمر المنع من السفر في قضايا

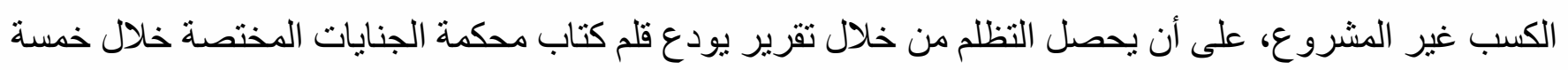

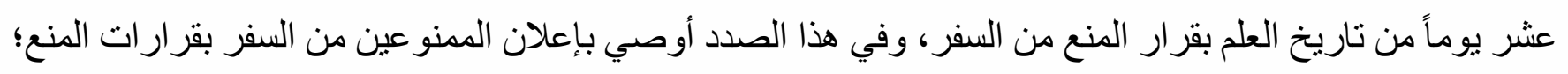
لأن من شأن ذلك الحد من إساءة استعمال السلطة أو الانحراف بها (توصية )، و عقب التقرير يحدد رئيس المحكمة جلسة لنظر التظلم يعلن بها المنظلم و النيابة العامة، وعلى المحكمة أن تفصل في النظلم من أمر المنع من السفر خلال خمسة عشر يو ماً من تاريخ التقرير به بقرار مسبب، وذللك بعد سماع أقو ال المتظلم و عضو النيابة العامة .

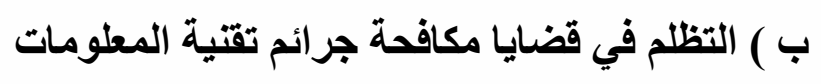
أوضح القانون أن لمن صدر ضده أمر بالمنع من السفر التظلم من هذا المنع أمام محكمة الجنايات المختصة وذللك

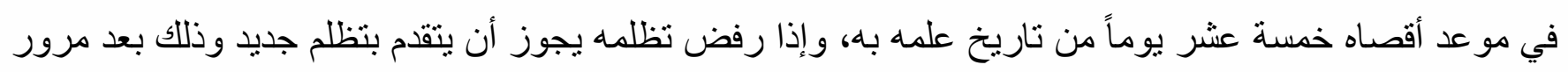

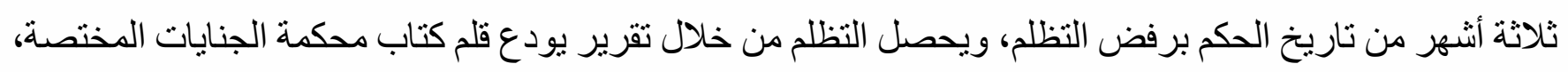

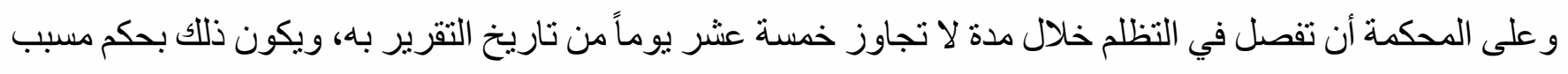

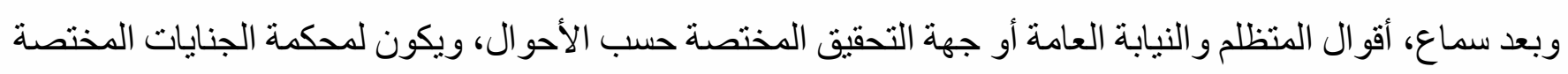
أنثاء نظر التظلم على قرار المنع من السفر أن تتخذ ما تراه من إجر اءات أو تحقيقات ترى لزومها في هذا الثأن . ثالثا_التظلم من الأوامر الصادرة من النائب العام: تتحدد جهات التظلم من أو امر النائب العام بالإدر اج على قو ائم الممنو عين من السفر بثلاث جهات وهي:

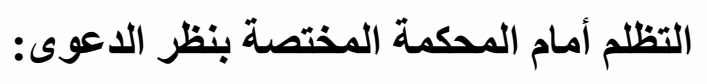




\section{محمد السعبد القز عة}

ويكون ذلك في حالة انتهاء التحقيقات، و إحالة الدعوى الجنائية إلى المحكمة المختصة، واتصال علم المحكمة،

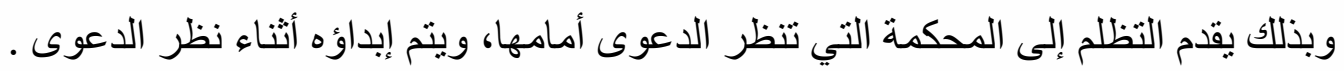

ب) التظلم أمام محكمة الجنح المستأنفة منعقدة في غرفة المشورة: يتحقق ذلك في حالة استمر ار التحقيقات و عدم إحالة الدعوى الجنائية إلى المحكمة المختصة، ويكون ذللك بتقديم طلب إلى رئيس المحكمة الابتدائية الو اقع في دائرتها المحكمة المختصة بنظر الدعوى، ويكون القرار الصادر من غرفة المشورة في موضوع التظلم نهائياً غير قابل للطعن.

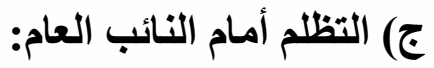

يجوز التظلم للنائب العام من القرار الصادر منه، وذلك بطلب يقدم إلى مكتبه، ويقيد هذا الطلب بدفتر معد لذلك، وللنائب العام أن يعدل من تلقاء نفسه دون أب تظلم عن هذا الأمر، وقد جرى العمل على إصدار تصـاريح مؤقتة بالسفر للأشخاص الصادر ضدهم أوامر بالمنع من السفر ، ويكون ذلك لحاجة ملحة كالسفر للعلاج أو إنجاز بعض الأعمال أو

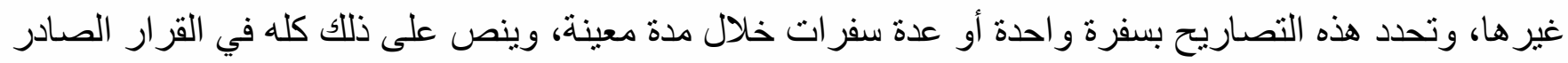
بالتصريح(171).

\section{رابعاً_مدة الإدراج على قوائم الممنوعين من السفر:}

تظل الأسماء المستوفية للبيانات المدرجة بالقو ائم من تاريخ الإدر اج، وترفع تلقائياً بعد انقضاء ثلاث سنوات تبدأ من أول يناير التالي لتاريخ الإدراج إذا لم برفع قبل انقضائها بناء على طلب الجهة الطالبة، ويستمر الإدراج بعد الإدي انقضائها إذا طلبت الجهة ذللك، ( و على الجهات التي لها طلب الإدر اج إعداد سجل خاص لديها بالأسماء التي سبق لها طلب إدر اجها بالقو ائم لمر اجعتها وتصنيفها في المواعيد المقررة، مع إخطار مصلحة وثائق السفر والهجرة والجنسية بالأسماء التي ترى استمر ار إدر اجها بالقو ائم في مو عد غايته نهاية شهر نوفمبر من كل عام، وتقوم إدارة القو ائم بالتصفية

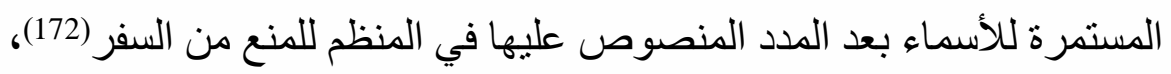
ويتعين عدم تجاوز مدة الإدراج على قوائم الممنوعين من السفر المدة المقررة لها قانوناً دون طلب استمرار الإدر اج؛ لأن الإدر اج لايكون أبدياً و إنما لثلاث سنوات ثمث ترفع الأسماء غير المستوفاة للبيانات بعد هذه المدة إلا إذا

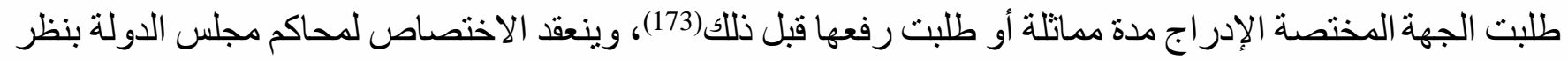


الطعن على القرار السلبي بامتناع الجهة الإدارية ممثلة في وزير الداخلية عن رفع الاسم من قوائم المنع من السفر بعد

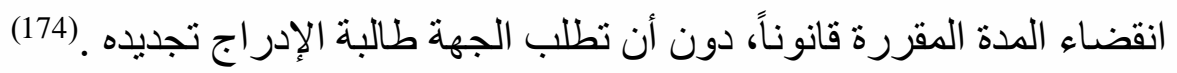

(174) الطعن رقم 48/11869 ق، جلسة 2016/12/26 مجموعة المبادئ القانونية التى قررتها المحكمة الادارية العليا في ربع قرن 1163. (2016/9/30-1991/10/1) 


\section{محمد السعبد القز عة}

\section{الخاتمة}

تمثلت الغاية من هذا البحث (المنع من السفر في المو اد الجنائية) في بيان أهمية حرية السفر والتنقل باعتبار ها من أسمى الحريات الملاصقة لنخص الإنسان، ور غم تلك الأهمية لهذه الحرية، إلا أنه وضعت عليها بعض القيود التي تحند

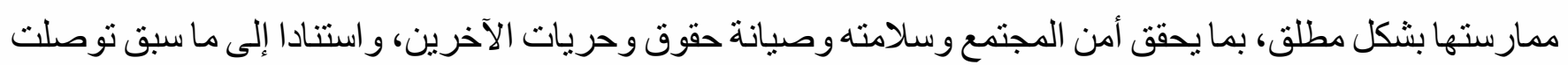
إلى مجمو عة من النتائج و التوصيات أوجز ها فيما يلي: مئي

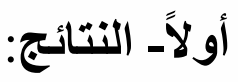

1- أوضح البحث مفهوم حرية السفر و المنع منه باعتباره قبد على حرية من أهم حريات الإنسان الأساسية، مبيناً

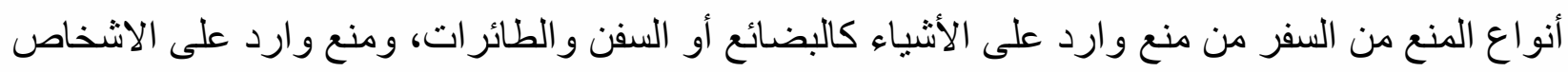

$$
\text { وهو المعني بالبحث. }
$$

3- بينت أن القيود الو اردة على حرية السفر ليست مقصورة على المو اد الجنائية فحسب، إنما توجد قيود على حرية

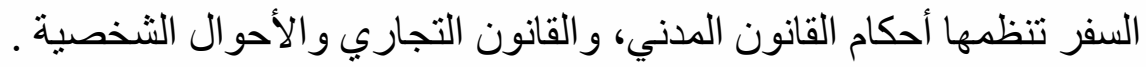
4- أظهر البحث مدى مشروعية القرارات المتعلقة بالمنع من السفر، باعتباره حالة و اقعية وممارسة عملية بالرغم من افتقاره لوجود سند تثريعي في قانون الإجر اءات الجنائية ينظم هذا الأمر. 5- أشار البحث إلى طبيعية الأمر بالمنع من السفر، وانتهيت إلى أن قرار المنع من السفر هو قرار إداري باعتبار سلطة إصداره ممنوحة لوزير الداخلية أو من يفوضه في هذا لألمر. 6- كثف البحث أن حرية السفر في مجمل الدساتير تندرج ضمن الحريات الأساسية، وقد تكفلت الدساتير الوطنية و التتريعات الداخلية بصيانتهاو الحث على ممارستها في سهولة ويسر، و لا يتم تقييد تلك الممارسة إلا في ضوء

$$
\text { الضو ابط المحددة قانوناً. }
$$

7- حفلت الثريعة الإسلامية بالنصوص الواردة في القران الكريم و السنة النبوية المؤكدة على حرية الإنسان في

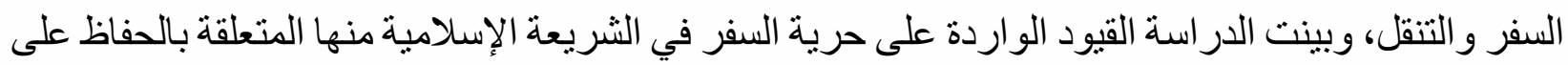
الأعر اض و الصحة، و لأغر اض تنظيمية . 8- جاء في البحث بيان حرية السفر في المو اثثق الدولية، والمو اثيق الإقليمية، ومدى مشروعية المنع من السفر في تلك المو اثيق. 9- عرضت لموقف بعض التشريعات المقارنة من المنع من السفر، وكذا بيان الأساس القانوني للمنع من السفر داخل مصر. 
10- تناول البحث صور المنع من السفر في بعض الجر ائم الجنائية كجريمة الكسب غير المشروع، وجر ائم الإرهاب

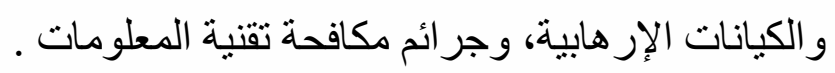

11- نطرق البحث إلى الأحكام الإجر ائية المتعلقة بالمنع من السفر في المو اد الجنائية عن طريق بيان من له سلطة

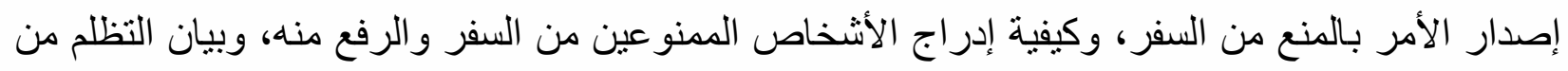

الإدر اج على قو ائم الممنو عين من السفر.

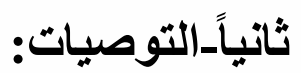

1- أناند المشر ع المصري بإقر ار نص تشريعي بقانون الإجر اءات الجنائية ينظم موضوع المنع من السفر باعتباره

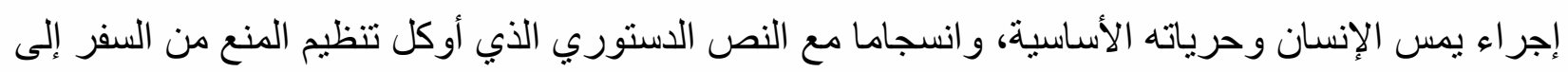
القانون وليس إلى قرار وزاري، ولإضفاء مشرو عية على قرار الات المنع من السفر.

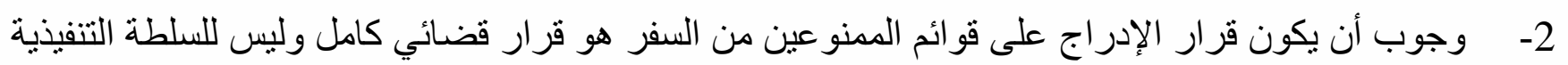

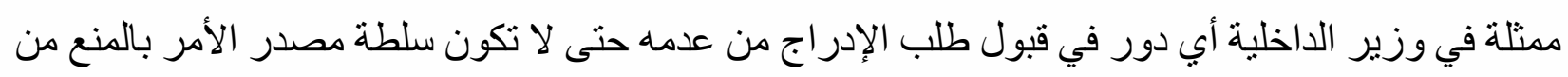
السفر سلطة منقوصة . 3- ضرورة إعلان المدرجين على قو ائم الممنوعين من السفر خلال 24 ساعة من تاريخ الإدر اج على تللك القو ائم، شريطة ألا يكون في هذا الإعلان مساس بالأمن القومي ومصالح البلاد العليا.

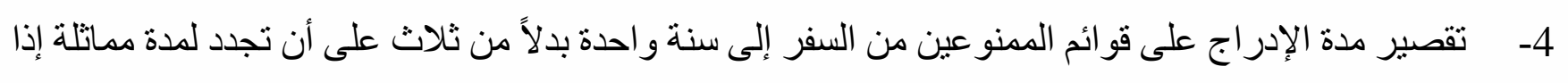
اقتضت الضرورة ذلك. 5- تحديد دائرة من دو ائر الجنايات في نطاق كل محكمة استئناف تحددها الجمعية العامة سنوياً تكون منعقدة في غرفة المشورة؛ لنظر النظلمات على قرار الإدر اج على قوائم الممنوعين من السفر، بما يضمن توفير ضمانة حقيقية للممنوع من السفر. 6- إجر اء تعديل تشريعي بالمادة 13مكررمن قانون الكسب غير المشروع من شأنه أن يسمح للمتظلم من الأمر بالمنع من السفر بالتظلم أمام دائرة جنائية خاصة غير التي تنظر موضو عادئ الدعوى حتى لا يؤثر نظر ها للتظلم

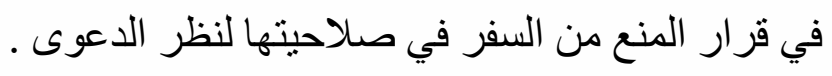




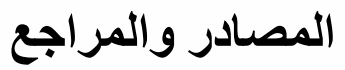

\section{المعاجم اللغوية}

1- أبو القاسم جار محمود بن عمر بن احمد الزمخشري، أساس البلاغة، تحقيق محمد باسل، الطبعة الأولى، دار الكتب العلمية، بيروت، لبنان، ج1، 1998.

2- على بن محمد الجرجاني، التعريفات، تحقيق مجمو عة من العلماء، الطبعة الأولى، دار الكتب العلمية، بيروت، لبنان، 1403 هـ، 1983م. 1983.

3- المعجم الوجيز، مجمع اللغة العربية، طبعة خاصة بوزارة التربية والتعليه، جمهورية مصر العربية، 1418هـــ .1997

كتب التفاسير:

1- اسماعيل بن عمر بن كثير، تفسير القر ان العظيم، تحقيق سامي بن محمد سلامة، الطبعة الثانية، دار طيبة للنشر

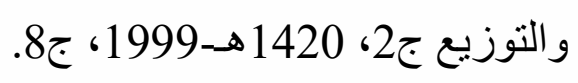

2- محمد بن جرير الطبري، جامع البيان في تأويل أحكام القران، الطبعة الأولى، مؤسسة الرسالة، بيروت، ج24،

$$
\text { كتب الاحاديث النبوية تاريخ نشر }
$$

1- عبد الله محمد بن اسماعيل بن ابر اهيم بن المغيرة البخاري، صحيح البخارى، كتاب تقصير الصلاة، باب في

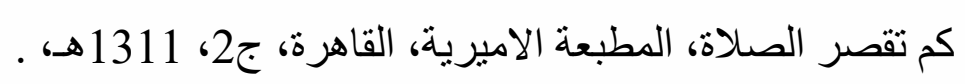

2- النَّسائي، أبو عبد الرحمن أحمد بن شعيب بن علي بن سنان بن بحر بن دينار - المتوفي سنة 303هـ، سنن

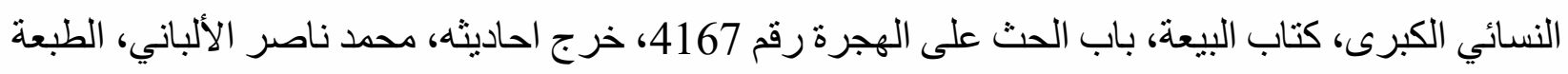
الأولى، مكتبة المعارف، الرياض.

كتب الفقه

1- ابن امير الحاج، التقرير و التحبير على التحرير في اصول الفقه، تحقيق عبدالله محمود، دار الكتب العلمية،

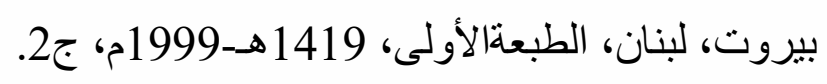

2- أبو البركات الدردير العدوى المالكي الأزهري، شرح الدردير على اقرب المسالك لمذهب الامام مالك، طبع

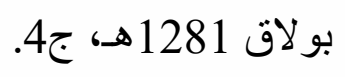

3- شهاب الدين احمد بن ادريس القر افي، الذخيرة، الطبعة الأولى، دار الغرب الإسلامي، بيروت، ج2، 1994.

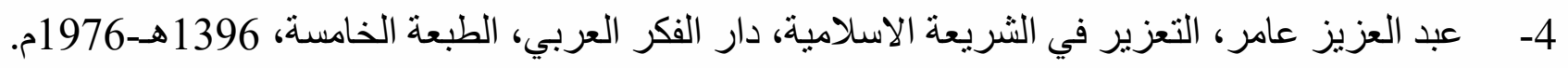




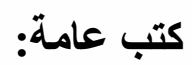

1- سيد سابق، فقه السنة، الطبعة الثالثة، دار الكتاب العربي، بيروت، لبنان، 1397هــ1977م.

2- طه حسين، الفتنة الكبرى (عثمان)-دار المعارف، مصر، 1951م.

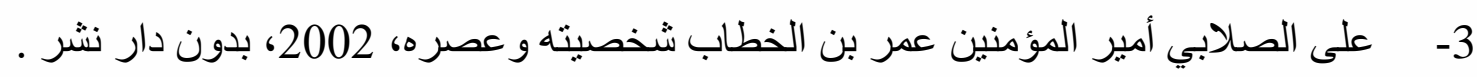

4- محد حسين هيكل، الفاروق عمر، مطبعة مصر ، 1364هـ.

الكتب القانونية العامة

1- أحمد فتحي سرور، القانون الجنائي الدستوري، الطبعة الثالثة، دار الثروق، القاهرة، 2004.

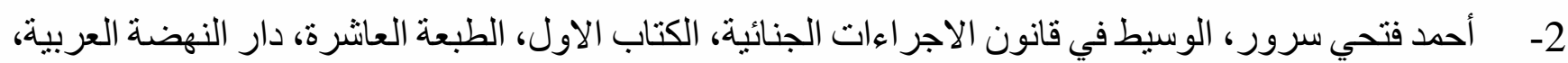

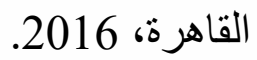

3- أثرف توفيق شمس الدين، شرح قانون الاجر اءات الجنائية، ج1، الطبعة الخامسة، دار النهضة العربية،

القاهرة، ج1، 2017.

4- حسين جميل، حقوق الانسان في الوطن العربي، مركز در اسات الوحدة العربية،بدون سنة نشر. 5- صبري الر اعي، رضا السيد عبد العاطي، الثرح و التعليق علي قانون الاجر اءات الجنائية ـفقها وقضاء-طبعة خاصة بنقابة المحامين، المجلد الثاني .

6- عبد الروؤف مهدي، شرح القو اعد العامة للإجر اءات الجنائية، دار النهضة العربية، القاهرة، 2002. 7- عبدالواحد محمد الفار، قانون حقوق الانسان في الفكر الوضعي والثريعة الاسلامية، دار النهضة العربية،

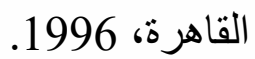

8- على صـادق ابو هيف، القانون الدولي العام، الطبعة الحادية عشر، منشأة المعارف، الاسكندرية، 1975. 9- عوض محمد عوض، قانون الاجر اءات الجنائبة، دار المطبو عات الجامعية، ج1، 1990. 10- محد سلام مدكور ، الوجيز لأحكام الاسرة في الاسلام، 1975،بدون دار نشر.

11- محمد عيد الغريب، شرح قانون الاجراءات الجنائية، النانر جامعة المنصورة، 1997 ـ. 12- محمود شريف بسيوني، الوثائق الدولية المعنية بحقوق الإنسان، المجلد الأول -الوثائق العالمية، الطبعة الأولى،

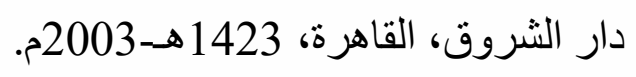

13- محمود شريف بسيوني، الوثائق الدولية المعنية بحقوق الإنسان، المجلد الثاني-الوثائق الإسلامية والإقليمية، الطبعة الأولى، دار الثروق،القاهرة، 1423 هـ-2003م. 14- محمود نجيب حسني، الدستور والقانون الجنائي، دار المطبوعات الجامعية، الاسكندرية، بدون رقم طبعة، .2020 


\section{محمد السعبد القز عة}

15- محمود نجيب حسنى، شرح قانون الاجر اءات الجنائبة، ج1، دار النهضة العربية، القاهرة، 2013. 16- مصطفي أبو زيد فهمى، فن الحكم في الاسلام، المكتب المصري الحديث، 1981. 17- نبيل مدحت سالم، شرح قانون الاجر اءات الجنائية، دار النهضة العربية، القاهرةج، 2، 18- نشأت الهلالي، التنظيم الدولي، دار النهضة العربية، القاهرة، 1994-1995. 19- وائل أحمد علام، الاتفاقيات الدولية لحقوق الانسان، دار النهضة العربية، القاهرة، 1999.

الكتب القانونية المتخصصة

1- ابر اهيم سيد احمد، المنع من السفر والتحفظ على الاموال فقهاً وقضاء، الطبعة الأولى، منشأة المعارف،

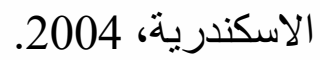

2- أحمد عبد اللاه المر اغي، السياسة الجنائية للأدر اج على قو ائم الار هاب، الطبعة الأولى، مركز الدراسات العربية

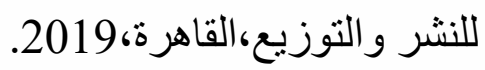

3- أسامة حسنين عبيد، السياسة الجنائية في الكسب غير المشروع دراسة مقارنة، دار النهضة العربية، القاهرة، .2016

4- أثرف توفيق شمس الدين، التو ازن بين السلطة والحرية ووجوب تقييد سلطة النيابة العامة في التحقيق، در اسة نقدية للقانون المصري مقارناً بالقانونين الألماني والفرنسي، الطبعة الثانية، دار النهضة العربية، القاهرة، 2015

5- أكمل يوسف السعيد يوسف، قوائم الكيانات الارهابية و الارهابيين في ضوء الثرعية الدستورية والجنائية، الطبعة الأولى، مركز الدراسات العربية للنشر والتوزيع، القاهرة، 1441هـ-2020م 6- ر رامي متولى القاضي، شرح قانون مكافحة جر ائم تقنية المعلومات رقم (175) لسنة 2018 مقارنا بالتشريعات المقارنة والمواثيق الدولية، الطبعة الأولى، مركز الدراسات العربية للنشر والتوزيع، القاهرة، 1441هـــ 2020

7- سيد احمد محمود، حول المنع من السفر، دار الكتب القانونية، القاهرة، 2007، بدون رقم طبعة . 8- عبد التواب معوض الثوربجي، المنع من السفر كإجر اء جنائي ــمقارناً بالحبس الاحتياطي، و الرقابة القضائية في التشريع الفرنسي-دار النهضة العربية، القاهرة، 2004. 9- جلى عرفة احمد، أوامر وقرار ات المنع من السفر(در اسة عملية)، المجمو عة المتحدة للطباعة والنشر، بدون رقم طبعة. 10- محمد بكر حسين، الحقوق و الحريات العامة -حق التنقل و السفر در اسة مقارنة بين الثريعة والقانون مدعماً بأحدث أحكام القضـاء الإداري، الطبعة الأولى، دار الفكر الجامعي، الاسكندرية، 2008. 
11- محمد زكى أبو عامر، الحماية الجنائية للحرية الثخصية، دار الجتمعة الجديدة، الاسكندرية، 2011. 12- محمد عثمان شبير، منع المدين من السفر في الفقه الإسلامي، مجلة دراسات العلوم الانسانية، الاردن، العدد

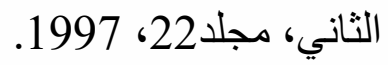

13- محد على سويلم، الاوامر التحفظية في الاجراءات الجنائية ـدراسة مقارنة، دار المطبوعات الجامعية،

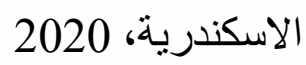

14- مصطفي مجدى هرجة، الاو امر على عر ائض ومناز عتها التنفيذية، دار الثقافة للطباعة و النشر التوزيع،1982.

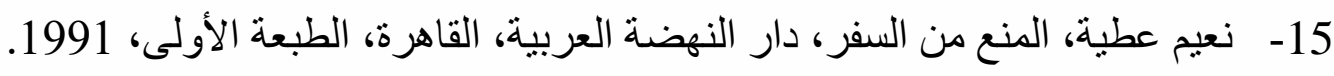
16- نعيم عطية، حسن محمد هند، النظام القانونى للمنع من السفر، دار الكتب القانونية، 2009، بدون رقم طبعة. 17- هثام عبد الحميد الجميلي، الموسوعة القانونية في جرائم التظاهر و التجمهر و الارهاب و امن الدولة طوارئ،

نادي القضاة، 2014.

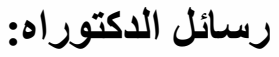

1- احمد جاد منصور، الحماية القضائية لحقوق الانسان، دراسة خاصة في حرية التنقل والاقامة في القضاء الإداري المصري، در اسة مقارنة، رسالة دكتور اه، كلية الحقوق، جامعة عين شمس، 1997. 2- عبد المجيد أحمد المنشاوي، حماية حقوق الانسان في الظروف الاستثنائية، دراسة مقارنة بين أحكام القانون الدولي و الثريعة الاسلامية، رسالة دكتور راه، كلية الحقوق، جامعة القاهرة، 2006، عبدالرحيم بن سيف بن على القصابي، الإكر اه البدني (در اسة تحليلية لحبس الددين ومنعه من السفر في كل من $-3$ القانونين العماني و المصرى) رسالة دكتور اة، كلية الحقوق -جامعة الاسكندرية، 2019. 4- محمد أحمد ابر اهيم عبد الباقي تليمة، الحماية القضائية للحرية الشخصية، رسالة دكتور اه ـكلية الحقوق -

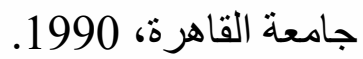
5- المهدى عبد الحميد العدل المهدى، مدى احترام حقوق الانسان عند مكافحة جر ائم الارهاب، رسالة دكتور اه، كلية الحقوق -جامعة المنصورة، 2014.

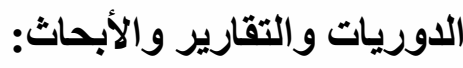
1- سن السيد بسيوني، حرية التنقل ومدى شرعية أوامر المنع من السفر الصادرة من قاضي الامور الوقتية، المحاماة، العددان الاول و الثاني -يناير وفبر اير 1991 السنة الحادية والسبعون. 2- ختم عبور، تقرير حول عقوبة المنع من السفر من يونيهيهاتسبتمبر 2016، اعداد مركز القاهرة لدر اسات

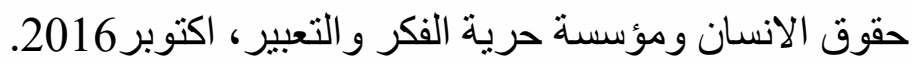




\section{محمد السعبد القزعة}

3- طارق حسين محمود، حرية السفر بين الاطلاق و التقييد در اسة قانونية تحليلية، مجلة الدراسات القانونية، كلية

$$
\text { الحقوق -جامعة أسيوط، العدد السادس و العشرون، يونيو } 2007 .
$$

4- عبد الله بن عبد الصمد القبيسي دعوى المنع من السفر، ورقة عمل مقدمة للعرض على الاجتماع الدوري لرئيس وقضاة المحكمة العامة بالرياض، 1438هـ.

5- فاضل نصر الله، الحق في التنقل وشرعية أوامر النيابة العامة من السفر (دراسة مقارنة)، مجلة الدراسات

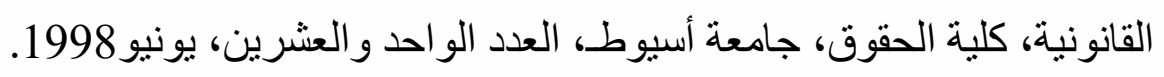

6- فتوح الثاذلي، المنع من السفر لا سند لله من القانون المصري ويهدر حقا دستوريا، موقع المفكرة القانونية،

$$
\text { بتاريخ 2013/12/31.تاريخ الزيارة 2020/6/10. }
$$

7- محد أبوزيد محمد، الضو ابط التنظيمية للحريات العامة وضماناتها -حرية التنقل والاقامة، أكاديمية مبارك للأمن، مجلة كلية الدر اسات العليا، العدد الثالث، يوليو 2000م-ربيع الاول 1421هــ.

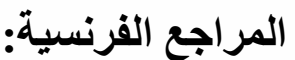

1- Claude- Albert Colliard, Libertés publiques, 6e éd, Paris, Dalloz, 1975.

2- conseil constit 28 nov 1973D .1974.

3- J. Morange, libertés publiques, 1985.

4- J. Vincent et J. Prévault, Voies d'exécution et procedures de distribution, 17e éd, No.17.

5- Jacques Godechot . Les constitution de la France depuis 1789, Edité par Gf Flammarion, Paris, 1995.

6- Le Tribunal des conflits 9 juin 1986.

7- M.Jean Rivero Et M.Jacques Robert, Cours de Libertés Publiques, Paris, 19691970.

8- Pierre Chambon, Le juge d'instruction: theorie et pratique de la procedure, Dalloz, 15 Avril, 1997.

9- Trib.adm. Strasbourg 3 nov .1983,D.S. 1983,300,note J-F.Flauss . 


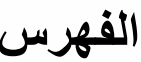

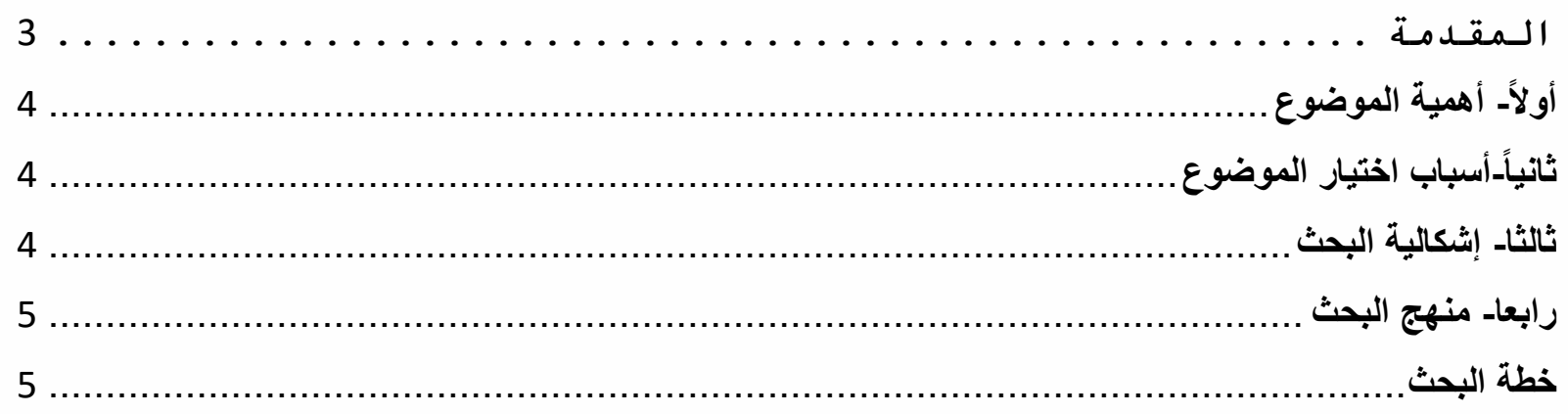

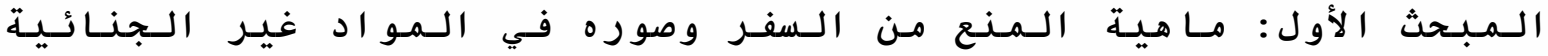

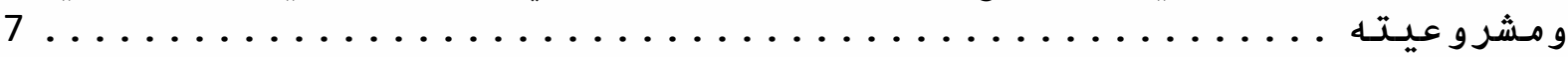
المطلب الأول: مفهوم المنع من السفر .

11

14

15

18 المطلب الثاني: صور المنع من السفر في غير المواد الجنائية. المطلب الثالث: مشروعية المنع من السفر وطبيعته القانونية مئ. الفرع الأول: مشروعية المنع من السفر الفرع الثاني: الطبيعة القانونية للمنع من السفر

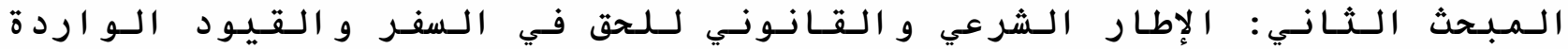

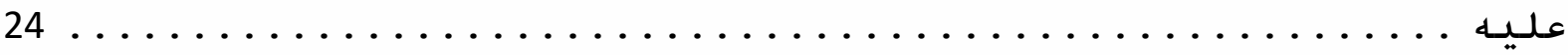
المطلب الأول: حرية السفر في الشريعة الإسلامية والقيود الواردة عليها . المطلب الثاني: حرية السفر ومشروعية المنع منه في المواثيق الاولية والإقليمية

29 الفرع الأول: حرية السفر ومشروعية المنع منه في المواثيق الدولية الفرع الثاني: حرية السفر ومشروعية المنع منه في المواثيق الإقليمية) المطلب الثالث: حرية السفر والمنع منه في التشريعات الوطنية. الفرع الأول: حرية السفر والقيود الواردة في الاساتير الفرع الثاني: حرية السفر في التشريعات الاخلية والقيود الواردة عليه

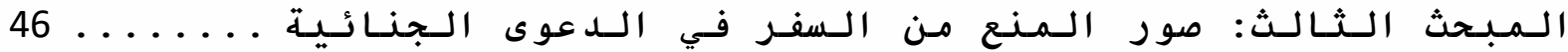
46 المطلب الأول: المنع من السفر في قانون الكسب غير المشروع

51 المطلب الثاني: المنع من السفر في تثريعات مكافحة الإرهاب

52 الفرع الأول: المنع من السفر في قانون تمويل الإرهاب والكيانات الإرهابية

56 الفرع الثاني: المنع من السفر في قانون مكافحة الإرهاب

59 المطلب الثالث: المنع من السفر في قانون مكافحة جرائم تقنية المعلومات

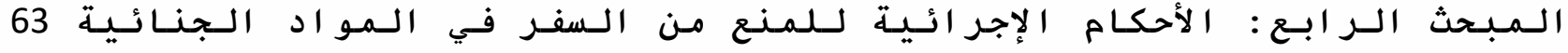
63

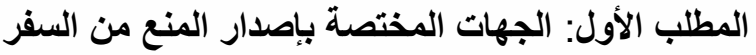


63

67.

69

70.

74

74

75

76

81
الفرع الأول: الإدراج على قوائم الممنوعين من السفر الصادر من جهات قضائية .. الفرع الثاني: المنع من السفر الصادر من جهات تنفيذية. المطلب الثاني: تنظيم إدراج الأشخاص الممنوعين من السفر والرفع منها لـانيات

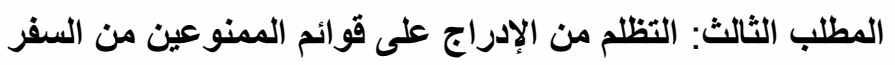

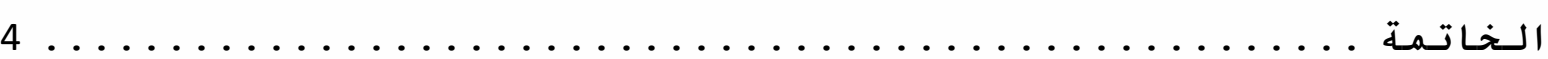

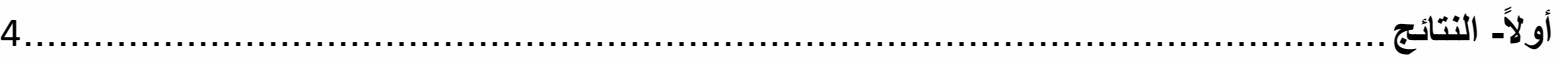

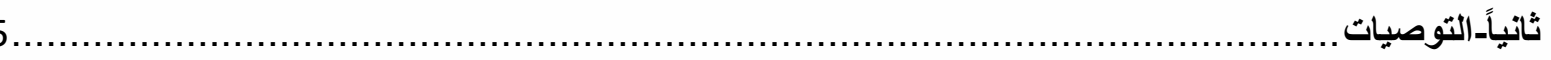

الـمصادر و الـمـر اجع

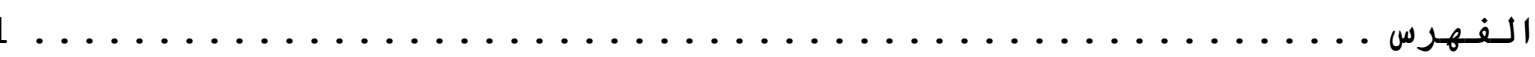


المنع من السفر في المواد الجنائية

محمد السعبد القز عة 
المنع من السفر في المواد الجنائية

محمد السعبد القز عة 
المنع من السفر في المواد الجنائية

محمد السعبد القز عة 
المنع من السفر في المواد الجنائية

محمد السعبد القز عة 